\title{
MUZYKA JAKO ŚRODEK NARRACJI W WYBRANYCH FILMACH MICHAELA HANEKEGO'
}

MACIEJ WOŹNIAK

Wydział Nauk Humanistycznych UKSW

Faculty of Humanities, Cardinal Stefan Wyszyński University in Warsaw

maciekwozniak@poczta.onet.pl

\section{WSTĘP: O SEYSZALNYM KRAJOBRAZIE KINA}

\author{
„O, ty, przemiano \\ uczuć w co? - w słyszalny krajobraz”
}

Rainer Maria Rilke, Do muzyki (tłum. A. Lam)

Kiedy Georges, jeden z bohaterów Miłości Michaela Hanekego, usiłuje złapać gołębia - ulicznego intruza we wzorcowo urządzonym mieszczańskim mieszkaniu - przez dobrych kilka minut widz zostaje sam na sam z trzepoczącym ptakiem i zadyszanym staruszkiem. W eseju Gołębie zagrażają kinu Zygmunt Kałużyński, wspominając o niemal sto lat wcześniejsze pionierskie lata filmu dźwiękowego, napisał: „Na szklanym dachu atelier siadywały gołębie, których gruchanie przerywało dialogi: specjalni funkcjonariusze dyżurowali tam, by przepędzać ptactwo kijami"2. Skojarzenie tych dwóch punktów w historii kina - leżących na dwóch biegunach filmu dźwiękowego - pozwala dostrzec w Hanekem nie tylko reżysera od „wstrząsają-

1 Artykuł stanowi przeredagowaną wersję rozprawy magisterskiej napisanej pod kierunkiem dr hab. Katarzyny Taras i obronionej na Wydziale Nauk Humanistycznych UKSW w 2016 roku.

2 Z. Kałużyński, Gołębie zagrażają kinu, [w:] idem, Buntownik bywalec, Warszawa 1998, s. 87. 
cych widzem" historii czy dyżurnego moralistę, ale też artystę organicznie związanego z rozwojem kina i jego środków wyrazu. Jeden z tych środków to dźwięk, zaś jego odmianą szczególną - a w przypadku filmów Michaela Hanekego wyjątkowo godną uwagi - jest muzyka.

Pozostańmy jeszcze na moment przy - zupełnie pozbawionej muzyki scenie $z$ gołębiem, ponieważ pozwala ona spojrzeć na sposoby narracji u Hanekego z perspektywy metody, czyli użytego „chwytu”3. Scena jest prowokująca, zarówno formalnie (sprawia wrażenie, że wypada z rytmu filmu, jest tak nieproporcjonalnie rozciągnięta w stosunku do całości, że może wzbudzić w widzu irytację oraz zniecierpliwienie ${ }^{4}$ ), jak i pod względem treściowym (zastawia pułapkę przymusu interpretacyjnego, czyli tak zwanego trybu symbolicznego ${ }^{5}$, w którą wpadł chociażby Tadeusz Sobolewski, cokolwiek zbyt łatwo sugerujący związek gołębia z symboliką chrześcijańską ${ }^{6}$ ). Skuteczność prowokacji jest tym większa, że do Hanekego przylgnęła nie tylko łatka perfekcjonisty, który każdą sekundę taśmy nagrywa $\mathrm{z}$ premedytacją, ale także reżysera, u którego gra z widzem nie zakłada równoprawności obu stron, tylko intelektualną oraz emocjonalną przewagę jednej z nich - czyli po prostu reżyserską manipulację widzem. Owszem, część filmów Hanekego, w tym Funny Games, może potwierdzać opinię „manipulatora”, ale takie obrazy jak Pianistka czy Miłość - czego dowodem

3 W. Szkłowski, Sztuka jako chwyt, tłum. R. Łużny, [w:] Teoria badań literackich za granica, t. 2, cz. 3, wyb. S. Skwarczyńska, Kraków 1986, s. 10-28.

4 „Najgorsze były długie, wręcz wlokące się sceny, które zamiast zachwycać, strasznie nużyły. Apogeum mojego zniecierpliwienia nastąpiło w momencie, kiedy Georges zaczął nie wiadomo po co polować na gołębia”; M. Piechocka, A. Kortus, http://inlovewithmovie.blogspot.com/2013/03/miosc-amour.html [dostęp: 20.08.16].

5 U. Eco, Tryb symboliczny, tłum. M. Woźniak, [w:] Teorie literatury XX wieku. Antologia, red. A. Burzyńska i M.P. Markowski, Kraków 2006, s. 304-353.

6 „Obijanie się gołębia o ściany paryskiego mieszkania symbolizuje również szamotaninę duchową współczesnego człowieka po utracie dawnej religijnej busoli"; T. Sobolewski Haneke z Miłościa, ale bez litości, „Gazeta Wyborcza” 2012, nr 256.

7 „Doskonała znajomość tego, czego spodziewa się publiczność, pozwala twórcy na manipulowanie jej uczuciami i reakcjami, sprawianie, że jej nadzieje momentalnie rozsypują się jak domek z kart”; J. Dudkiewicz, „Funny games” czyli po co to ogladasz? - analiza filmu Michaela Hanekego, http://film.org.pl/a/analiza/ 
choćby skrajne rozbieżności w ich ocenie ${ }^{8}$ - pokazują, że bywa także inaczej: wydarzenia i bohaterowie uwalniają się spod ścisłej reżyserskiej kontroli, co pozwala im na samostanowienie, widzowi zaś - na konfrontację z filmowym światem na tyle wielowymiarowym, że nie mieści się w ramach standardowo pojmowanego „niepokoju moralnego” czy przesłania zgodnego z obowiązującą „pedagogiką społeczną".

To osiągnięcie wolności przez filmowe wydarzenia i bohaterów odbywa się w dużej mierze dzięki wybitnym aktorom (których silne osobowości i bogate zawodowe życiorysy wykluczają pokorne posłuszeństwo dyrektywom oraz pozbycie się „własnych” emocji), a także dzięki wybranej do filmów muzyce. Chodzi tu przede wszystkim o tak zwaną muzykę klasyczną, czyli napisaną $\mathrm{w}$ poprzednich epokach, potem wykonywaną w określonych okolicznościach oraz kontekstach historycznych lub społecznych (można by ją określić, ze współczesnej perspektywy, jako „muzykę po przejściach” - i do tego sformułowania jeszcze wrócę, ponieważ uchyla ważną interpretacyjną furtkę). Emancypacja muzyki w kolejnych filmach austriackiego reżysera, jej coraz mniej schematyczne użycie, coraz odważniejsze „wchodzenie w buty” narratora, komentatora czy analityka ekranowych wydarzeń, potwierdzają choćby i to, że nie ma jednego - zasuszonego jak liść między stronicami

funny-games-czyli-po-co-to-ogladasz-analiza-filmu-michaela-hanekego-36176/ [dostęp: 1.03.16].

8 „Haneke nakręcił jeden z najpiękniejszych filmów o śmierci, ale i o tytułowej miłości”; R. Błaszczak, Miłość, http://kafeteria.pl/kultura/milosc-michael-haneke-a_5375 [dostęp: 1.04.16]. „Wybaczcie krnąbrność, ale uważam, że ten film jest festiwalem bezpłciowych oczywistości ubranym w grubą warstwę pseudoambitności, dodatkowo okryty nieprzekonującą symboliką. Niedomówienia scenariusza nie stawiają pytań, których byśmy nie znali. Decyzje bohaterów nie dają odpowiedzi, które mogłyby prowokować do szczerych i nowych przemyśleń"; P. Rezmer, Miłość, http:// stacjakultura.pl/4,21,29422,Milosc_recenzja_filmu,artykul.html [dostęp: 1.04.16].

9 „- Ale nie chcę przez to powiedzieć, że mój film jest jakiegoś rodzaju przesłaniem. Przesyłki nadajemy na poczcie, a nie na ekranie kina (śmiech).

- Broni się Pan przed określeniem »moralista«.

- Moralista to nudziarz, nauczyciel, któremu się wydaje, że wszystko wie lepiej”. Era Wilków [z Michaelem Hanekem rozmawiają Anna Chorostecka i Jan Niedziela], „Gazeta Wyborcza” 2001, nr 278. 
filmowej encyklopedii - Michaela Hanekego. Jest za to żywy artysta kina, który zmienia się i ewoluuje, podobnie jak sztuka, którą uprawia.

W niniejszej pracy chcę przeanalizować rolę muzyki w filmach Hanekego oraz wykazać, jak i dlaczego przejmuje ona rolę narratora wobec przedstawianych wydarzeń. Czyniąc to albo równolegle z tradycyjnym kinowym narratorem, czyli obrazem, albo samodzielnie, ujawnia ona te aspekty historii, których oko kamery nie dostrzega. Na początku w skrócie prześledzę historię muzyki w kinie, wychwytując momenty pozostawiające zauważalny ślad w filmach Hanekego. Przegląd jest nader skrótowy i skupiony na wczesnych dekadach rozwoju kina - wszystko to, by pokazać, jak głęboko biją źródła muzycznej narracji u Hanekego. Śledząc zdobycze kina pod kątem muzycznej narracji, pokażę, że artystyczna droga Hanekego, jego zmieniający się punkt widzenia (czy raczej, w tym przypadku, „punkt słyszenia”), nawiązuje do różnic w spojrzeniu na narrację w filmie i sposoby jej budowania u najwybitniejszych reżyserów sprzed lat (vide opinia Tarkowskiego o Eisensteinie, którą zacytuję).

W kolejnych rozdziałach omawiam dokładniej - z perspektywy muzycznej narracji - trzy filmy Hanekego: Funny Games (1997), Pianistkę (2001) i Miłość (2012). Charakter mojej pracy, pisanej z punktu widzenia kulturoznawcy, sprawia, że skupiam się bardziej na opowiadaniu filmowej historii za pomocą utworów muzycznych w kontekście obecności tych kompozycji we wspólnej przestrzeni kulturowej niż na teoretycznej analizie filmoznawczej (z jej historią pojęć określających sposób istnienia muzyki w filmie, począwszy od klasycznej pracy Siegfrieda Kracauera i jego terminów „muzyka komentująca” czy „muzyka funkcjonalna” ${ }^{10}$ ). Zadowalam się zatem względnie prostszym podziałem na sferę diegetyczną i niediegetyczną ${ }^{11}$, nie podążam

${ }^{10}$ S. Kracauer, Teoria filmu. Wyzwolenie materialnej rzeczywistości, tłum. W. Wertenstein, Gdańsk 1975, s. 174-177 i 178-186.

${ }^{11}$ „Diegeza - pojęcie diegesis, oznaczające w języku greckim »opowiadanie«, $\mathrm{w}$ tradycji retorycznej [...] było przeciwstawiane pojęciu mimesis, czyli »naśladowania«. [...] W odniesieniu do filmu termin upowszechnił E. Souriau [...]. Souriau rozróżnia przestrzeń ekranową (daną bezpośrednio na ekranie) i przestrzeń diegetyczną (pomyślaną przez twórców filmu i rekonstruowaną przez widza w trakcie oglądania filmu). [...] Do świata diegetycznego należy zarówno przestrzeń (i czas) bezpośrednio przedstawione na ekranie, jak i przestrzeń (i czas) domniemane jako niezbędne dopełnienie tego, co w filmie jest pokazywane. Dźwiękiem diegetycznym 
natomiast za proponowanym przez Jerzego Płażewskiego podziałem na muzykę immanentną i transcendentną. Będę przy tym korzystał z rozpoznań Płażewskiego, tyle że bez szczegółowego trzymania się jego terminologii ${ }^{12}$.

Wybieram akurat te trzy filmy Hanekego dlatego, po pierwsze, że reżyser używa w nich wielu muzycznych chwytów narracyjnych (których rozpoznanie sprzyja lepszemu wglądowi w opowiadaną na ekranie historię, a także pogłębionej interpretacji filmu), po drugie dlatego, że ukazują one, jak na przestrzeni kilkunastu lat zmieniała się narracyjna rola muzyki u Hanekego: ku coraz wnikliwszemu wglądowi pod podszewkę wydarzeń, coraz bogatszemu (intelektualnie, emocjonalnie, duchowo) komentarzowi do akcji filmu, a wreszcie - ku wyzwoleniu kina spod wizualnego nadzoru kamery. Dzieje się tak po to, by film (wraz z bohaterami, ich historiami, poruszonymi problemami) mógł - tak jak wiersz u Andrzeja Sosnowskiego ${ }^{13}$ „wyjść z domu”, czyli wyrwać się spod kurateli twórcy, zamiast jedynie instrumentalnie służyć (idei, przesłaniu, przestrodze itd.).

Zamierzam przeanalizować, w jaki sposób stopniowa emancypacja muzyki w omówionych przeze mnie filmach wpływa na emancypację bohaterów i wydarzeń (bo ścieżka dźwiękowa przestaje jedynie „ilustrować tezy” czy

w filmie jest dialog postaci widocznych w kadrze lub muzyka płynąca ze źródła, które jest obecne w obrazie albo którego obecność zakładamy (np. radia samochodowe w American Graffiti G. Lucasa z 1973 r.), dźwiękiem niediegetycznym jest muzyka ilustracyjna towarzysząca zdarzeniom i postaciom. Komedie M. Brooksa zawierają żarty na temat dźwięku niediegetycznego, który okazuje się dźwiękiem diegetycznym (w Płonących siodłach z 1974 r. szeryfowi Bartowi w drodze do Rock Ridge przygrywa zespół Counta Basiego, koncertujący właśnie na prerii, zaś w Lęku wysokości z 1977 r. w scenie jazdy autostradą "źródłem « ilustracyjnego akompaniamentu jest autobus z grającą orkiestrą Johna Morrisa)". J. Ostaszewski, hasło: Diegeza, [w:] Słownik filmu, cz. 1, red. R. Syska, Kraków 2010.

12 Jerzy Płażewski wyróżnia: (1) muzykę immanentną (źródło w kadrze), (2) muzykę transcendentną (źródło poza kadrem). Trzy funkcje muzyki immanentnej: (a) muzyka jako element akcji, (b) muzyka jako ilustracja, (c) muzyka jako żart. Trzy funkcje muzyki transcendentnej: (a) muzyka imitatorska, (b) muzyka ilustratorska, (c) muzyka samoistna. Przytaczam za: J. Płażewski, Język filmu, Warszawa 2008, s. 341-352.

13 „Wiersz wychodzi z domu i nigdy nie wraca”. A. Sosnowski Wiersz (Trackless), [w:] idem, Taki, Wrocław 2003. 
tė̇ „ukazywać postawy”). Czasami wsłuchanie się w muzycznego narratora potrafi nawet zmienić nastawienie do całego filmu. Możliwość takiej sytuacji zasugeruję na przykładzie Funny Games (choć udział muzyki w tym filmie jest objętościowo niewielki, ograniczony prawie wyłącznie do pierwszych scen), w którym analiza pojawiających się na początku utworów - pod kątem kulturowego porządku, jaki reprezentują - umożliwia zmianę nastawienia do dalszej części filmu. Właśnie muzyka doprowadzi mnie do wniosku, że poddana przemocy rodzina wcale nie jest taka „niewinna”, jak zwykło się przyjmować w omówieniach Funny Games, zaś terror, który ją spotyka, wcale nie jest „anonimowo” totalitarny, ponieważ jego źródło bije niepokojąco blisko takich instytucji, jak opera czy filharmonia. Jeszcze bardziej złożone zmiany perspektywy w odbiorze filmu chcę pokazać na przykładzie muzyki z Pianistki oraz Miłości - tak samo zwracając uwagę na znamienny fakt, że decydując się na użycie tak zwanej muzyki klasycznej, czyli istniejącej od stuleci i wrośniętej w tkankę kultury Zachodu (a nie komponowanej specjalnie do filmu), Haneke pozbawia się dużej części władzy nad filmem i jego możliwymi interpretacjami.

Przy okazji omawiania skutków wykorzystywania kompozycji historycznie „używanych”, a więc siłą rzeczy uwikłanych w zmiany społeczne i kulturowe napięcia, chcę zwrócić uwagę na podobną - jak w przypadku muzyki - rolę znanych i mocno osadzonych w historii kina aktorów występujących u Hanekego. Ten przykład posłuży mi do pełniejszego uzasadnienia tezy, że elementy budujące filmową narrację - niezależnie od pierwotnych intencji reżysera - wnoszą do konkretnego filmu dużo więcej niż swoją estetyczną formę. Barokowa i postromantyczna muzyka w Funny Games czy też kompozycje z epoki muzycznego romantyzmu w Pianistce pozostawiają znacznie mocniejsze „echo semantyczne"14 niż ich czysto brzmieniowa obecność w filmach. To „echo”, niosące rozbudowane sensy i znaczenia, może być dla odbiorcy filmu jeszcze ciekawsze, kiedy Michael Haneke używa muzyki niejako wbrew jej pierwotnemu charakterowi, na przekór narzucającemu się kontekstowi, w tym także na przekór stereotypowym, utrwalonym regułom użycia kompozycji muzycznych w kinie komercyjnym ${ }^{15}$ (tak robi np.

${ }^{14}$ Z. Lissa, Czy muzyka jest sztuką asemantyczną?, „Myśl Współczesna” 1948, nr 10 .

15 „[Wojciech Kilar:] Za obrzydliwą formę muzyki filmowej uważam tę, która pozornie towarzyszy filmowi, dublując inne jego elementy i czerpiąc siłę 
z utworem Johna Zorna, zagłuszającym operowe arie w Funny Games, albo z kompozycją Schuberta, brzmiącą na tle kabiny sex shopu w Pianistce). Dzięki temu Haneke, niejako przy okazji, uszlachetnia swoje dzieła, przenosząc je na wyższe piętra sztuki filmowej.

W niniejszej pracy spróbuję wykazać, dlaczego muzyczna narracja u Michaela Hanekego ma decydujący wpływ na artystyczną rangę jego filmów. Zaryzykuję przy tym hipotezę, że tyle, ile arbitralnej władzy traci reżyser, tyle zyskuje film - na podmiotowości jego bohaterów i głębi opowiadanej historii. Nie dotyczy to zresztą tylko reżysera, ponieważ nawet kompozytor nie jest w stanie kontrolować wszystkich sensów generowanych przez stworzoną przez niego muzykę, tym bardziej że po procesie montażu i ostatecznym spotkaniu dźwięku z obrazem tworzą się nowe poziomy znaczeń (Wojciech Kilar mówił w tym kontekście o nieświadomym i niezamierzonym $z$ góry, a nader istotnym wpływie muzyki na akcję filmu ${ }^{16}$ ). Według Michela Foucaulta, nowoczesna podmiotowość (nowoczesne „ja”) zrodziła się z wizualnego ujarzmienia, z ciągłej obserwacji, jakiej każdy jest poddany ${ }^{17}$. Smutne skutki takiego stanu rzeczy pokazują filmy Hanekego, ale równocześnie muzyka, jaka się w nich pojawia - czasem niezgodna z punktem widzenia kamery, a czasem wręcz „spiskująca” przeciwko niej pełni rolę buntowniczą, rebeliancką wobec nadzorującego film oka. Michael Haneke odżegnuje się od publicznej interpretacji swoich filmów, pozwalając im żyć własnym życiem - życiem dzieł artystycznych, otwartych. W mojej pracy chcę pokazać, że jednym z jego sojuszników w tej strategii jest użyta w filmach muzyka i że jej emancypacja pociąga za sobą emancypację bohaterów i całej filmowej rzeczywistości. Z zamknięcia w kadrze ku otwarciu na świat.

W eseju o filmie Miłość nawet zdradzający niekiedy skłonność do światopoglądowego szufladkowania reżyserskich intencji Tadeusz Sobolewski

z konkretnych, fizycznych wydarzeń ekranowych. To znaczy, że jeśli galop konia - to rytmy na ten temat; jeśli wzburzone morze - to glissanda harfy; jeśli scena miłosna, to obowiązkowo skrzypce". J. Cegiełła, Szkice do autoportretu polskiej muzyki współczesnej. Rozmowy z kompozytorami, Kraków 1976, s. 82-83.

16 Zob. L. Polony, Kilar. Żywioł i modlitwa, Kraków 2005.

17 Zob. M. Foucault, Nadzorować i karać. Narodziny więzienia, tłum. T. Komendant, Warszawa 1998. 
w końcu przyznaje, że „obecna w filmie delikatna symbolika jest przezroczysta, wywiedziona z konkretnych sytuacji"18. Dalej idzie Jakub Majmurek, który na trzeźwej ocenie, że „gołąb jest tu na szczęście tylko gołębiem, nie symbolem ducha świętego czy jakiejkolwiek innej zbłąkanej transcendencji”, opiera sugestię, iż „ta w gruncie rzeczy komiczna, "nic nieznacząca scena« pojawiająca się tuż po najbardziej dramatycznym momencie w filmie, daje poczucie obcowania $z$ wielkim kinem, dotykającym prawdy być może nieuchwytnej w jakimkolwiek innym medium"19. Wniosek Majmurka - nawiązujący mimochodem do uwagi Szkłowskiego, że „chwyt” w sztuce nie ułatwia nam „zrozumienia” przedmiotu, lecz jego „percepcję, ma służyć nie „poznawaniu”, lecz „widzeniu”20 - sporo mówi o podejściu do filmowych środków wyrazu, które czynią z filmów Hanekego rodzaj dzieła otwartego ${ }^{21}$, a więc wymykającego się jednoznacznej interpretacji czy zamknięciu w wygodnym schemacie.

Jeżeli wrócimy teraz znowu na drugi biegun dziejów kina dźwiękowego - do czasów, kiedy z gołębiami zmagali się nie aktorzy, lecz pracownicy techniczni, którzy „wypędzali je poza obszar filmowej diegezy” - będziemy mogli prześledzić (w dość radykalnym skrócie) drogę, jaką pokonała muzyka w filmie, by jego „słyszalny krajobraz” mógł zabrzmieć tak, jak to się dzieje w filmach Michaela Hanekego.

\section{SKĄD SIĘ WZIĘŁA MUZYCZNA NARRACJA U HANEKEGO}

Historycy filmu w dużej mierze zgadzają się, że u zarania kina muzyka pojawiła się w celu zagłuszenia hałaśliwych aparatów projekcyjnych, a dopiero później zauważono, że potrafi istotnie uzupełniać przekaz wizualny ${ }^{22}$.

18 T. Sobolewski, op. cit.

19 J Majmurek, I to jest ta cała miłość?, „Krytyka Polityczna”, www.krytykapolityczna.pl/Blogfilmowy/MajmurekItojesttacalamilosc/menuid-85.html [dostęp: 1.01.16].

20 W. Szkłowski, op. cit. s. 10-28.

${ }^{21}$ Zob. U. Eco, Dzieło otwarte: Forma i nieokreśloność w poetykach współczesnych, tłum. L. Eustachiewicz, Warszawa 2008.

22 I. Sowińska, hasło: Dźwięk w kinie, [w:] Encyklopedia kina, red. T. Lubelski, Kraków 2003, s. 272. 
Z filmoznawcami nie zgadzają się natomiast niektórzy antropolodzy kultury, którzy twierdzą, że muzyka leży w samej „naturze” kina, a jej rytmiczne czy harmoniczne struktury, albo nawet właściwości określonych gatunków muzycznych, są ukryte w filmowych kadrach ${ }^{23}$. Ta różnica poglądów wydaje się mniej istotna z punktu widzenia historycznego, natomiast sygnalizuję ją, ponieważ ma znaczenie dla niniejszej pracy, w której podejście kulturoznawcze czy interdyscyplinarne (szukające związków z innymi dziedzinami sztuki) do filmów Michaela Hanekego bierze górę nad analizą czysto filmoznawczą. Filmy Hanekego, analizowane od strony muzycznej (dziejów muzyki, kontekstów związanych z poszczególnymi utworami i ich obecnością w kulturze), potrafią ujawnić swoje niedostrzegalne dotąd znaczenia, którym „skąpiono uwagi”24, ponieważ twórczość reżysera zwykło się omawiać według stereotypowych kluczy (moralista, skandalista itp.). Aby znaleźć dla muzyki w filmach Hanekego tak głębokie konteksty, na jakie zasługuje, wypada zacząć od początku.

W moim krótkim przeglądzie dziejów muzyki w filmie będę podążał dwiema ścieżkami: prześledzę rozwój sztuki filmowej w kontekście historycznym, koncentrując uwagę na pierwszym półwieczu kina (tutaj oprę się w dużej mierze na dwóch tomach Historii kina pod redakcją Tadeusza Lubelskiego, Iwony Sowińskiej i Rafała Syski ${ }^{25}$ ), oraz przyjrzę się z osobna wybranym klasycznym dziełom filmowym, w których użyto muzyki w sposób przełomowy, a pomysły muzyczne w nich wykorzystane znajdują po latach swoje echo w filmach Michaela Hanekego (tu skorzystam głównie z pierwszych tomów Kina, wehikułu magicznego Adama Garbicza ${ }^{26}$ ).

${ }^{23}$ „Kino jest ze swej natury muzyczne, tak jak opera, choć widzowie nie zdają sobie z tego sprawy”. E. Morin, Kino i wyobraźnia, tłum. K. Eberhardt, Warszawa 1975, s. 110.

${ }^{24}$ „Za pośrednictwem muzyki film otwiera się na kulturowy (a nawet: cywilizacyjny) kontekst w sposób wyjątkowy i zasługujący na uwagę, której dotąd mu skąpiono". I. Sowińska, Polska muzyka filmowa 1945-1968, Katowice 2006.

25 Historia kina, t. I: Kino nieme, red. T. Lubelski, I. Sowińska, R. Syska, Kraków 2009; Historia kina, t. II: Kino klasyczne, red. T. Lubelski, I. Sowińska, R. Syska, Kraków 2012.

26 A. Garbicz, J. Klinowski, Kino, wehikuł magiczny. Przewodnik osiąnięć filmu fabularnego. Podróż pierwsza 1913-1949, Kraków 1981; A. Garbicz, Kino, wehikut 
Do mniej więcej 1905 roku muzykę w kinie odtwarzano głównie z urządzeń typu patefon czy pianola, a taperzy - czyli akompaniujący filmowi pianiści - pojawili się początkowo po to, by zmniejszyć wrażenie „mechaniczności kina” jako medium (jak sugeruje Iwona Sowińska: „dlatego t.[aper] zawsze pozostawał w polu widzenia publiczności stanowiąc dodatkową atrakcję"27). Rola tapera zmieniła się w drugiej dekadzie XX wieku, kiedy produkcję kinową zdominowały filmy fabularne, a samo kino zaczęło udowadniać, że chce być czymś więcej niż „jarmarczną" rozrywką lub sposobem dokumentalizowania rzeczywistości. Wtedy rozpoczęła się także stopniowa emancypacja muzyki w filmie. Taperzy albo improwizowali, uważnie śledząc rozwój fabuły i nadążając za zmianami przekazu emocjonalnego, albo korzystali z kartotek przygotowanych zawczasu utworów (niekiedy dedykowanych konkretnemu filmowi), uwzględniających - i wypełniających stosownym motywem - nawet przerwy na zmianę rolki w projektorze. O rosnącym poziomie taperów i ich biegłości nie tylko w odtwórczym, czysto pianistycznym rzemiośle, najlepiej świadczy fakt, że od tego fachu zaczynał karierę wybitny kompozytor Dymitr Szostakowicz.

Badając początki obecności muzyki w filmie, trzeba od razu oddzielić pojęcie „muzyki w filmie” i „muzyki filmowej”, ponieważ ta pierwsza pojawiała się u samych początków kina (potocznie określanego jako „kino nieme”, które jednak nigdy nie było kinem „bezdźwiękowym”), ta druga zaś upowszechniła się kilkanaście lat później pod postacią kompozycji pisanych specjalnie do kinowych produkcji (na spory dystans czasowy między tymi dwoma formami zwraca uwagę Alicja Helman ${ }^{28}$ ). Niezależnie od innych dźwięków, zarówno utwory muzyczne wzięte skądinąd, jak i utwory pisane na potrzeby rodzącego się przemysłu kinowego były obecne przez większość okresu znanego jako „kino przeddźwiękowe” (czyli przez pierwsze trzy dekady rozwoju kina - do roku 1927) ${ }^{29}$.

Warto przy tym zauważyć, że choć na Zachodzie brak dźwięku w filmie od początku wydawał się problemem technicznym, z którym należało się

magiczny. Przewodnik osiagnięć filmu fabularnego. Podróż czwarta 1967-1973, Kraków 2000.

27 I. Sowińska, Przełom dźwiękowy, [w:] Historia kina, t. 2, op. cit.

28 Zob. A. Helman, Na ścieżce dźwiękowej: o muzyce w filmie, Kraków 1968.

29 Zob. Z. Lissa, Estetyka muzyki filmowej, Kraków 1964. 
uporać, to $\mathrm{w}$ Japonii niemym filmom towarzyszył narrator, zwany benshi, który na żywo opisywał akcję filmu oraz interpretował dialogi. Benshi przypominali raczej aktorów teatralnych niż lektorów, a ich rodowód sięgał tradycyjnego teatru kabuki. Tymczasem jednak w Europie i Ameryce potrzeba wzbogacenia muzycznego komentarza zaowocowała rozwinięciem instrumentarium: taperom zaczęli towarzyszyć skrzypkowie, a potem zespoły muzyczne. Równolegle zaczęto instalować w kinach tak zwane organy Wurlitzera, czyli instrument, który potrafił naśladować brzmienie orkiestry, a także rozmaite naturalne odgłosy.

Bogatsze kina mogły sobie pozwolić na angażowanie regularnych, „żywych" orkiestr, a jedną z pierwszych, które wniosły do kina symfoniczny sznyt i ambicje muzyki poważnej, była London Symphony Orchestra. Pierwszym kompozytorem o nazwisku uznanym wcześniej w filharmoniach, który zdecydował się na debiut w kinie, był Camille Saint-Saëns, który z 1908 roku skomponował muzykę do Zabójstwa księcia Gwizjusza Charlesa le Bargy i André Calmettesa - filmu przełomowego pod wieloma względami: po raz pierwszy opatrzonego listą nazwisk twórców i aktorów, a także cieszącego się opinią pierwszego filmu artystycznego (muzyka w nim „składała się ze wstępu oraz pięciu części; kompozytor operował orkiestrą smyczkową, fortepianem i fisharmonią"30). Kolejny wstrząs estetyczny otwierający muzyce w filmie ogromne perspektywy - wywołał niezwykły rozmach orkiestrowej partytury napisanej przez Josepha Carla Breila do Narodzin narodu Davida W. Griffitha z 1915 roku. Taki rozwój wydarzeń zaczął przyciągać do kina kolejnych klasycznie wykształconych kompozytorów. Niektórzy - jak wcześniej wspomniany Dymitr Szostakowicz - w filmie rozpoczynali karierę, zatem od początku mieli szansę docenić możliwości muzyki filmowej. Innych - jak Siergieja Prokofiewa - film zachęcił gwałtownym rozwojem środków artystycznych (nie było to jednak regułą, bo na przykład Igor Strawińki przejawiał do idei komponowania muzyki do filmu daleko idącą estetyczną niechęćs1).

30 A. Helman, op. cit., s. 10.

31 „Stosunek muzyki do akcji dramatycznej jest taki sam, jak muzyki w restauracji do rozmowy przy stoliku. Nie mogę tego uznać za muzykę". I. Dahl, Igor Strawiński on Film Music, [cyt. za:] S. Kracauer, op. cit., s. 4. 
Pojawienie się na przełomie lat 20. i 30. filmu dźwiękowego nie tylko związku kompozytorów z kinem nie unieważniło, ale wręcz wzmocniło, otwierając przed muzyką - która mogła być teraz nagrywana w studiu, a podczas montażu precyzyjnie dopasowywana do scen - niesłychanie szerokie perspektywy.

\subsection{OD SZANSONISTKI Z KABARETU DO PIANISTKI Z KONSERWATORIUM}

Za pierwszy pełnoprawny film dźwiękowy powszechnie uznawany jest Śpiewak jazzbandu w reżyserii Alana Croslanda z 1927 roku, choć wcześniej miało premierę kilka filmów z mniej lub bardziej zaawansowanymi próbami synchronizacji obrazu z muzyką (np. ambitny pod tym względem Don Juan tegoż Croslanda z roku 1926). W Śpiewaku także nie wszystko było udźwiękowione, niekiedy pojawiły się jeszcze kadry z napisami zamiast dialogów. Aktorzy (od)zyskali mowę w rok późniejszych Światłach Nowego Jorku Boba Foya. Początkowo pojawienie się dźwięku w filmach zostało przez artystów kina przyjęte bez entuzjazmu: dla reżyserów oznaczało to odejście od doskonalonych przez lata $\operatorname{metod}^{32}$, zaś dla aktorów - rezygnację ze specyficznie nadekspresyjnego stylu, który wielu z nich uczynił gwiazdami ${ }^{33}$. Aby ten stan rzeczy mógł się zmienić, trzeba było poczekać na pierwsze filmy, w których muzyka, i w ogóle warstwa dźwiękowa, pojawiły się nie dlatego, że była już taka technologiczna możliwość, tylko dlatego, że stanowiły artystycznie przemyślaną część dzieła, poszerzającą pole jego środków wyrazu. Za pierwsze filmy, w których muzyka jest równoprawnym partnerem obrazu i decyduje o emocjonalnej sile utworu i głębi jego przekazu, uznaje się Dusze czarnych Kinga Vidora z 1930 roku oraz Błękitnego anioła Josefa von Sternberga z 1931 roku.

W filmie Vidora uderza, z jednej strony, autentyzm użytych motywów (akcja dzieje się w Alabamie, w środowisku afroamerykanów - stąd muzyka

32 „Filmowcy wielkiego formatu nie mogli się wewnętrznie pogodzić z koniecznością przewartościowania tak wyśmienicie już wypracowanej stylistyki filmu bez głosu”. Dusze Czarnych, [w:] A. Garbicz, J. Klinowski, op. cit., s. 157.

${ }^{33} \mathrm{O}$ dramatycznym aspekcie przełomu dźwiękowego w dziejach kina w niezrównany sposób opowiada film Bulwar Zachodzącego Słońca Billy’ego Wildera z 1950 roku. 
bluesowa, soulowa, negro spirituals) i ich organiczny związek z fabułą (pełne wewnętrznego żaru „czarne” songi stają się równoległą do obrazu narracją o niszczącej sile erotycznej namiętności), a z drugiej strony - równie nowatorskie potraktowanie ciszy, która pozwala na niezwykle sugestywne wprowadzenie dźwięków naturalnych albo na podnoszenie poziomu emocji w momentach, kiedy widz raptem sam musi sobie dopowiedzieć, co się stało. Traf chciał, że drugi film z pierwszej pary dźwiękowych arcydzieł kina, czyli Błękitny anioł, także opowiada o fatalnym seksualnym zauroczeniu, muzyka zaś z podobną brawurą (choć tym razem zamiast autentycznego folkloru mamy piosenki skomponowane specjalnie do filmu ${ }^{34}$, a zamiast głosów reprezentujących całą afroamerykańską tradycję muzyczną - głos jednej jedynej Marleny Dietrich) wkracza w świat ludzkiej świadomości i podświadomości, portretując go równolegle z obrazem.

Warto zatrzymać się dłużej przy tym drugim filmie, co pozwoli skojarzyć kilka zasadniczych wątków i metod twórczych obecnych u von Sternberga z wątkami i metodami twórczymi, które siedemdziesiąt lat później pojawią się u Michaela Hanekego, a także zauważyć, że ich nośnikiem jest muzyka u obu reżyserów wykorzystana (czy raczej: nadająca filmowi niebywale intensywne życie) w podobny sposób. Urodzony w stolicy Austrii Josef von Sternberg jako dziecko wyjechał do Stanów Zjednoczonych, lecz po kilku dekadach, już jako uznany filmowiec, wrócił do Europy (na zaproszenie niemieckiej wytwórni UFA). Wrócił, by zrobić film nie tylko zbyt śmiały obyczajowo jak na ówczesne amerykańskie standardy, ale też mierzący się z psychologicznymi i społecznymi problemami z ducha ,europejskimi”, a już szczególnie związanymi $\mathrm{z}$ atmosferą Niemiec i Austrii, które to państwa poddaje reżyser (w końcu - pochodzący z Wiednia) swoistej psychoanalizie ${ }^{35}$.

${ }^{34}$ Piosenki śpiewane przez Marlenę Dietrich skomponował Friedrich Holländer. Wywodził się on ze znanej rodziny zamieszkałej w Głubczycach, a zanim zrobił karierę w Hollywood, od osiemnastego roku życia pisał przeboje dla berlińskich kabaretów, więc z mistrzostwem potrafił oddać atmosferę pełną erotycznych podtekstów, zajrzeć za pomocą muzyki w mrok ludzkiej podświadomości; chętnie sięgał w tym celu do formy walca jako muzycznego motywu miłosnego.

${ }_{35}$ „W jego dziele chodzi o ukazane $\mathrm{z}$ wielką przenikliwością duchowe wnętrze Niemiec. Rygor porządku prowadzi tu do niepohamowanego wyładowania wszystkich niszczycielskich instynktów, kiedy tylko nadarzy sie ku temu okazja; 
Poszukiwaczem podobnych (i mających zbliżone źródła) zbiorowych traum jest Michael Haneke, który urodził się co prawda w niemieckiej Bawarii, ale w Wiedniu spędził młodość i zdobył wykształcenie. Efektem tego jest pokrewieństwo ideowe oraz artystyczne obu twórców, szczególnie widoczne, jeżeli porównać Błękitnego anioła i Pianistkę - w jednym i drugim filmie obserwujemy zmagania „kultury wysokiej” z „niskimi pobudkami”, „kulturalnej” moralności, dyscypliny społecznej, sztuki - z „naturalnym”, nagim istnieniem. Przy czym w obu filmach muzyka dochodzi do uszu widza wcale nie zza kadru czy z tła wydarzeń (jako ich ilustracja czy komentarz), tylko $\mathrm{z}$ centrum filmowej diegezy, tętniąc w samym sercu konfliktu.

Jeden z najbardziej sugestywnych efektów von Sternberg osiąga, kiedy zderza pieśń o tradycyjnych wartościach, płynącą z zegara w miejskim ratuszu, z kabaretowym songiem ku chwale fizycznej miłości, zmysłowej i nieokiełznanej - i słychać w tym zderzeniu całą kolizję wartości, jaką zgotował przełom XIX i XX stulecia (winowajcy krachu wartości tworzą nader szacowną ławę oskarżonych, na czele z Darwinem, Freudem, Einsteinem i Nietzschem). Przełom XX i XXI stulecia okazuje się dla ludzkiego ciała i duszy niewiele łaskawszy - o czym donosi Michael Haneke, zderzając uduchowione kompozycje klasyków i szlachetne wnętrza filharmonii z podłą atmosferą sex shopów i porno-klubów, których tyleż potajemnym, co regularnym gościem jest szacowna pianistka. Haneke donosi o tym wszystkim nieuprzejmie, czyniąc bohaterkę - wyrafinowaną koneserkę Bacha i Schuberta - osobą uzależnioną od ostrej pornografii i sadomasochistycznego seksu.

Obydwa filmy łączy także odwaga reżyserów we wkraczaniu na zakazane w kinie mainstreamowym obszary, „zarezerwowane” choćby dla kina pornograficznego - i w obu przypadkach ich filmy okazują się na tyle wybitne, by wykraczać daleko poza wymiar obyczajowego „skandalu”. Pianistka zawiera sceny pod względem seksualnym drastyczne, nawet jak na liberalną współczesną Europę (Błękitny Anioł w purytańskiej atmosferze przedwojennej Ameryki budził porównywalne zgorszenie), ale ich obecność

rygor surowej mieszczańskiej moralności przynosi klęskę i upadek jednostce, którą namiętność zmusiła do sprzeniewierzenia się ideałom: tak oto brak wolności prowadzi do zwyrodnienia”. Błękitny Anioł, [w:] A. Garbicz, J. Klinowski, op. cit., s. 169. 
dodaje do filmu Hanekego nowe piętra znaczeń i sensów (także w kontekście emocji, jakie wywołuje u widza, oraz pytania: kto właściwie jest bohaterem pianistki? - które zadam przy okazji analizy filmu i towarzyszących mu reakcji $)^{36}$.

Oczywiście, odpowiednikiem „treściowym” tytułowej bohaterki Pianistki, Eriki - akademickiej wykładowczyni fortepianu, wcale nie jest w Błękitnym Aniele Lola - kabaretowa szansonistka, tylko uwiedziony przez nią, szanowany i pryncypialny nauczyciel, profesor Rath. Jednak można dopatrzeć się kilku „formalnych” analogii w sposobie kreślenia za pomocą muzyki portretów obu kobiet i obrazów ich relacji ze światem. $Z$ jedną wszakże zasadniczą różnicą. Wykreowana przez Marlenę Dietrich Lola stała się - w dużej mierze dzięki walorom wokalnym - jedną z ikon kobiecej seksualności, co spowodowało przejęcie tego wizerunku przez kulturę masową i wpłynęło na ewolucję wzorca kobiecości w XX wieku. Natomiast zagraną przez Isabelle Hupert Erikę - której neurotyczną urodę wzmacnia makijaż fortepianowej klasyki - można uznać za antybohaterkę kultury, zepchniętą na ciemną stronę. Erika jest rewersem tej samej „kobiecości”, której awersem jest Lola.

\subsection{OD FABRYKI MARZEŃ DO MANUFAKTURY KOSZMARÓW}

Wróćmy jednak do przerwanego wcześniej wątku - czyli do lat 30. ubiegłego wieku. W okresie upowszechniania się filmu dźwiękowego pojawiło się pokolenie kompozytorów, których można już nazwać filmowymi, ponieważ kino stało się dla nich najważniejszym polem działania oraz źródłem dochodów. Obok takich nazwisk, jak Maurice Jaubert, Joseph Kosma, Alfred Newman, Miklós Rózsa, Max Steiner, Herbert Stothart czy Dmitri Tiomkin, można jednym tchem wymienić pochodzącego z Polski Bronisława Kapera (laureata Oscara za muzykę do filmu Lili). Twórcy ci osiągnęli dojrzałość twórczą w tak zwanej Złotej Erze Hollywood, trwającej - według jednych

${ }^{36}$ „Sztandarowe książki Lindy Williams czy Montgomery'ego Hyde’a [socjolodzy zajmujący się historią pornografii i jej miejscem w kulturze - przyp. M.W.] lokują dosadne reprezentacje seksualności w kontekście historii sztuki, socjologii, antropologii, sposobów reprezentacji, dyskursów nad kobiecością, studiów filmoznawczych itd.”. P. Sołodki, Rubieże przyjemności. Seksualna niesubordynacja na obrzeżach amerykańskiej kinematografii, Gdańsk 2015, s. 467. 
historyków kina - do końca lat 40. (czyli do wyroku Sądu Najwyższego USA, który zakończył działalność monopolistycznego sytemu kin studyjnych podporządkowanych wielkim wytwórniom), zaś według innych badaczy aż do połowy lat 60. i przełomu kontrkulturowego, co może sugerować, że cały okres da się zamknąć w latach wprowadzenia i uchylenia cenzorskiego kodeksu Haysa ${ }^{37}$. Podstawowe cechy muzyki filmowej z okresu „Golden Age” to odwołania do XIX-wiecznego neoromantyzmu (Max Steiner był uczniem klasycznych kompozytorów - Johanesa Brahmsa i Gustava Mahlera), potężne składy symfonicznych orkiestr, a także zachowawczość w trzymaniu się określonych - oczekiwanych przez widza i nienaruszających zastanych kanonów - środków wyrazu.

Pozostańmy jeszcze przez chwilę w trzeciej dekadzie XX stulecia, kiedy równolegle z rozkwitem Hollywood oraz wytwórni niemieckich - nastąpił gwałtowny rozwój kinematografii rosyjskiej. Podwaliny pod tak zwaną rosyjską szkołę montażu położyli z jednej strony Lew Kuleszow i Wsiewołod Pudowkin (swym słynnym eksperymentem $z$ twarzą, którą sfilmowali w trzech różnych kontekstach za pomocą trików montażowych, co spowodowało trzy różne reakcje widzów), z drugiej zaś strony Siergiej Eisenstein,

37 „Gdy w 1922 r. szefowie wielkich wytwórni filmowych powołali Motion Pictures Producers and Distributors Association, kierowanie nim zaproponowali ówczesnemu amerykańskiemu Generalnemu Poczmistrzowi. Funkcję tę pełnił William Harrison Hays, prominentny polityk, działacz rządzącej Partii Republikańskiej. Nie dość, że cieszył się zaufaniem i poparciem Białego Domu, to jeszcze był dostojnikiem Kościoła prezbiteriańskiego. [...] W 1934 r. prawem przewidującym kary stał się kodeks, który przeszedł do historii jako »Kodeks Haysa«. [...] Tak powstał dziwaczny, szczegółowy zbiór komicznie dziś brzmiących nakazów, które ogólnie sprowadzały się do zasady, iż »sympatia widzów nigdy nie powinna być po stronie zbrodni, zła i grzechu«. [...] Wpływ zmian społecznych i obyczajowych, decyzje Sądu Najwyższego oraz działania organizacji na rzecz swobód obywatelskich wymusiły znaczne złagodzenie kodeksu w 1966 r. Co prawda nadal kładł on nacisk na cnotę i potępiał grzech, ale jeśli chodzi o seks, nie zakazywał go, a jedynie zalecał umiar w podejmowaniu tego tematu. $Z$ drugiej strony zwracał baczniejszą uwagę na sceny przemocy. W $1968 \mathrm{r}$. kodeks został zastąpiony przez system klasyfikujący filmy wedle wieku, jaki widz powinien mieć, by je oglądać”. Ł. Dziatkiewicz, Narodziny filmowej cenzury, „Dziennik”, dodatek „Weekend” z dnia 31.05.2014 r. 
który opublikował słynny artykuł Montaż atrakcji. Jego tekst (zamieszczony w czasopiśmie awangardystów) stawiał fundamentalną dla rozwoju kina tezę, że zestawienie dwóch obrazów (z czego niedaleko do wniosku, że także: obrazu i muzyki) nie jest ich sumą, ale całkiem nową jakością. Czyli w efekcie podawał definicję filmowej metafory.

W tym samym okresie Dżiga Wiertow, absolwent psychoneurologii, który kręcił w latach 1917-25 szereg kronik filmowych, stworzył manifest „Kino-Oko", w którym głosił wierność rzeczywistości, ale zakładał opisywanie jej za pomoca języka-montażu. Co prawda u Pudowkina i Wiertowa ów język pozostał jeszcze wyłącznie na poziomie wizualnym ${ }^{38}$, ale już Eisenstein który dał pierwszy popis wizualnego montażu w filmie Październik z 1929 roku - do pracy nad Aleksandrem Newskim z 1938 roku zaprosił Siergieja Prokofiewa, co zaowocowało arcydziełem harmonii „obraz-muzyka”. Dla reżysera najistotniejsze były metafora i kontrapunkt: to nad tymi środkami, podczas niezwykle długiego i precyzyjnego procesu montażu, pracowali z kompozytorem, którego rola dalece wykraczała poza samo napisanie muzycznej partytury ${ }^{39}$. Eisenstein od początku odrzucał ideę ilustracyjności muzyki czy też jej jakkolwiek „mimetycznej” funkcji wobec pokazywanego obrazu (w czym zaczął się właśnie specjalizować Hollywood, za pomocą ścieżki dźwiękowej ujednolicając i ujednoznaczniając przekaz wizualny).

Wcześniej jednak do głosu - w sensie dosłownym - doszli także inni rosyjscy filmowcy. Siergiej Rutkiewicz i Fridrich Ermler zamówili u Dymitra

38 Pudowkin zachwyca rytmem zmiennych kadrów w Burzy nad Azja z 1928 roku, natomiast Wiertow oszałamia dynamiką obrazów w rok późniejszym Człowieku z kamerą.

39 „Nad Aleksandrem Newskim twórcy pracowali w niesłychanym tempie. Przeglądając w nocy nakręcony materiał, już przed południem Prokofiew przynosił napisaną muzykę, od której Eisenstein uzależniał ostateczny kształt sceny. O współpracy tej reżyser pisał: »Są sceny o obrazie zmontowanym według muzyki uprzednio nagranej na taśmie dźwiękowej. Są sceny, do których ilustracja muzyczna została skomponowana na podstawie obrazu oglądanego w ostatecznej wersji montażowej. Są sceny realizowane w najrozmaitszych wariantach. [...] Z Prokofiewem zawsze się długo targujemy, kto pierwszy. A spieramy się dlatego, że pierwszemu przypada w udziale zasadniczy twórczy trud: ustalić odpowiedni rytm sceny«". A. Helman, op. cit., s. 75. 
Szostakowicza pierwszą stricte filmową suitę orkiestrową, którą dopasowali potem do scen swojego filmu Turbina $50000 \mathrm{z}$ roku 1932. Bardziej spektakularne rezultaty włączenia muzyki w strukturę montażową osiągnięto w filmie My z Kronsztadu Jefima Dzigana z 1932 roku. Utwory napisane do filmu przez Nikołaja Krukowa organicznie wrastają w tkankę wydarzeń, w dźwięki otaczające bohaterów, zaś śpiewana w jednej ze scen Międzynarodówka jest tak wpisana w dramaturgię filmu, że działa jednocześnie na poziomie realistycznym (śpiew w bitewnym zgiełku) i symbolicznym ${ }^{40}$.

Wszystko to było oczywiście podporządkowane komunistycznej ideologii i budzeniu w widzu odpowiedniej świadomości (co zresztą skończyło się, kiedy tylko Stalin umocnił się u władzy). Mimo to trzeba podkreślić, że $\mathrm{w}$ porównaniu $\mathrm{z}$ wyrafinowaniem środków użytych przez rosyjskich reżyserów, przemysłowa wytwórczość „marzeń”, których fabrykami były studia w Hollywood, ograniczała się (przy podobnym zamiarze: sformatowania emocji widza) głównie do utwierdzania estetycznych schematów przy unikaniu artystycznego ryzyka. Symbolem hollywoodzkiego stylu (ścieżek dźwiękowych balansujących między dętym patosem a ckliwym smyczkowym liryzmem) może być urodzony w 1901 roku Alfred Newmann, który napisał muzykę do ponad trzystu filmów i był - w co trudno uwierzyć - czterdzieści pięć razy nominowany do Oscara (statuetkę odebrał skromne dziewięć razy). Na szczęście każda reguła wymaga istnienia wyjątków. U takich hollywoodzkich kompozytorów jak Jerry Fielding i Elmer Bernstein (obaj urodzeni w 1922 roku) noworomantyczna symfonika bywała często przełamywana: a to motywami z folkloru meksykańskiego (Bernstein w Siedmiu wspaniałych Johna Sturgesa, Fielding w Dzikiej bandzie Sama Peckinpaha), a to śmiałymi i chwytliwymi tematami nie tyle komentującymi, ile napędzającymi akcję (Bernstein w marszu wojskowym z Wielkiej ucieczki Sturgesa, Fielding w sugestywnie mrocznych motywach z Dajcie mi głowę Alfredo Garcii Peckinpaha).

Współpraca Jerry’ego Fieldinga z Samem Peckinpahem przywodzi na myśl inne wybitne duety kompozytorsko-reżyserskie, w których muzyka nie ograniczała się do ilustracji scen, na przykład tandem Bernard Herrmann Alfred Hitchcock, współpracujący ze sobą dobrych kilkanaście lat, choć

${ }^{40}$ My z Kronsztadu, [w:] A. Garbicz, J. Klinowski, op. cit., s. 256. 
stał tu na przeszkodzie skrajnie trudny charakter obu artystów. Co ciekawe, mimo sukcesów z Hitchcockiem (choćby w Psychozie, gdzie surowa oszczędność muzycznych motywów tym mocniej spaja je $\mathrm{z}$ akcją), bodaj jeszcze wspanialsze rezultaty osiągnął Herrmann przedtem i potem, czyli na samym początku i u kresu kariery kompozytora filmowego. Jego debiutem w kinie była muzyka do Obywatela Kane’a Orsona Wellesa, w której pojawiły się - analogiczne do zniekształceń obrazu - dysonanse i zawirowania, natomiast ostatnim filmem, do którego napisał ścieżkę dźwiękową (i którego premiery, niestety, już nie dożył), był Taksówkarz Martina Scorsese, gdzie motywy miękko zorkiestrowane symfonicznie raptem ustępują, zgodnie z przyspieszającym pulsem filmu, przed improwizacjami jazzowymi (co ma metaforyzować nie tylko wydarzenia przedstawione w samym filmie, ale także rzeczywistość lat 70.).

Taksówkarz miał premierę w 1974 roku, ale żeby w ogóle doszło do jego nakręcenia (tudzież do powstania całego nurtu mrocznych i gwałtownych filmów z lat 70., których twórcy, obserwując rzeczywistość od innej niż dotychczas strony, wypracowali nowe sposoby widzenia i słyszenia), konieczna była o kilka lat wcześniejsza rewolta w łonie całej zachodniej kultury. W połowie lat 60. amerykańscy twórcy śmielej otworzyli muzykę filmową na jazz (np. wspomniany już Elmer Bernstein) czy rytmiczną muzykę pop (np. Lalo Schifrin, autor przebojowego motywu z Mission Impossible). Miejsce masywnych i mieszczańsko sytych motywów orkiestrowych zajęły kapryśnie synkopujące melodie i chwytliwe piosenki (choćby duetu Simon i Garfunkel w filmie Absolwent - jednym z symboli kontrkultury), zaś w aranżacjach przybyło ironii i stylistycznej przewrotności.

Specjalistą od tych ostatnich był Ennio Morricone, który tworzył wraz z Sergio Leone jeden ze słynnych duetów reżysersko-kompozytorskich. Obaj zaczynali od serii tak zwanych spaghetti-westernów z lat 60., których znaczenie dla sztuki filmowej zaczęto doceniać dopiero kilka dekad później. Morricone włączył do partytur filmowych dźwięki naturalne (strzały, gwizd, odgłosy zwierząt, łamanie patyków), szacowne brzmienie rodem z filharmonii zderzał z efektami psychodelicznymi czy industrialnymi (zgrzyt pociągu, chwiejący się na wietrze metalowy szyld), regularnie sięgał po rzadko spotykane instrumenty (harmonijka ustna, okaryna, drumla), a podniosłe melodie „ku pokrzepieniu serc” zastąpił zawadiackimi tematami sławiącymi raczej męską dzielność i zaradność niż stojące za nimi intencje (niekiedy 
nader ambiwalentne moralnie). W późniejszej twórczości Morricone nieco się ustatkowal, ale motyw fletni pana z Dawno temu w Ameryce Sergio Leone, kolizja melodyjnego tematu ze złowrogim motywem niby rozstrojonej orkiestry we Franticu Romana Polańskiego czy przemyślne kontrapunkty europejskiej symfoniki z indiańskim folklorem w Misji Rolanda Joffé mają swoje estetyczne źródła w cyklu na pozór błahych filmów o przemocy, zachłanności i podłości.

Rozmaite moralne i estetyczne niepokoje filmu lat 70. uległy stopniowej komercjalizacji (jak przypominają co przytomniejsi: kina nie wymyślili artyści, ale inżynierowie i przemysłowcy), ale cieszące się jak zwykle największą popularnością kino gatunkowe pozostało nimi zainfekowane. Na polu muzyki filmowej upowszechnił się np. model action score (czyli po prostu muzyka kina akcji), który ma dynamizować przebieg wydarzeń (znakomite okazują się synkopujące motywy jazzowe), podtrzymywać napięcie (wszak nowoczesne kino akcji to jedno z dzieci klasycznego thrillera, tyle że źródłem nerwowego pulsu bywa skromniejsze instrumentarium) i pozostawiać widza w poczuciu zagrożenia i niepewności, także tej wykraczającej poza salę kinową (tu nieoceniona jest elektronika, także ta najsurowsza, bliska muzyce industrialnej - utwory Vangelisa do Łowcy Androidów Ridleya Scotta to jeden z najbardziej spektakularnych przykładów jej zrośnięcia się z filmowym obrazem).

Pamiętając o nominacji do Oscara za rok 2015 dla Johna Williamsa za muzykę do siódmej już części cyklu Gwiezdne wojny, warto cofnąć się o dwie dekady i przypomnieć tło, na jakim powstała ścieżka dźwiękowa do pierwszej części cyklu - z 1977 roku. Wtedy - w otoczeniu muzyki kina lat 70., wspomnianej w kilku poprzednich akapitach - taki powrót nie tylko do symfoniczności, z jej gestem melodycznym i patetycznym nastrojem (motyw z czołówki, marsz imperium), ale w ogóle do atmosfery „złotego wieku” Hollywood, miał w sobie odświeżającą siłę, wartą choćby Oscara (którego Williams wówczas dostał). Natomiast przyczyną nominacji w roku 2016 nie jest ani muzyczna wartość nowych utworów zasłużonego kompozytora, ani w jakikolwiek sposób zaskakujące czy przewrotne ich użycie, lecz skłonność Hollywood do pewnej estetyki - a żadnej estetyki nie oderwiemy od światopoglądu czy hierarchii wartości.

Kiedy w scenie otwierającej Funny Games Michaela Hanekego kulturalna mieszczańska rodzina słucha $\mathrm{z}$ samochodowego odtwarzacza tradycyjnej 
muzyki klasycznej, którą przerywają ataki gwałtownego noise’u granego przez zespół Johna Zorna, można odebrać to jako zapowiedź, skrót czy nawet diagnozę mających nastąpić dramatycznych wydarzeń. Ale można też umieścić tę scenę w szerszym kontekście muzyki filmowej, która tkwiąc korzeniami w XIX-wiecznej tradycji symfonicznej (i stojącym za nią modelu życia), na przemian zrywała i powracała do tych inspiracji.

Zgiełk zespołu Naked City, wybuchający w rodzinnym aucie i brzmieniowo miażdżący arie z klasycznych oper, jest na tyle gwałtowny, że przebija się nie tylko ku dalszej części filmu - przez kruchą karoserię chronologicznego przebiegu wypadków - ale wydostaje się w ogóle na zewnątrz dzieła Hanekego. Jego pogłos (czyli wspomniane już „echo semantyczne”) słychać w długim na stulecie hallu historii kina.

\subsection{OD NATURALNOŚCI DO DOSKONAŁOŚCI. I Z POWROTEM}

Oczywiście, historia muzyki w kinie nie ogranicza się do naprzemiennej dominacji stylu rodem z Hollywood i „nadgryzania” go przez wpływy z Europy. Linie podziałów i różnic są dużo bardziej zawiłe. Odrębną, niezależną drogę wybrał w latach 30. René Clair, u którego dochodzi do swoistego „mocowania się” obrazu z dźwiękiem ${ }^{41}$. Świat filmów Claira tętni życiem zarówno w sferze wizualnej (nadaktywni bohaterowie w komediowych sytuacjach o Chaplinowskim odcieniu, ale w realiach miasteczkowej Francji), jak i audialnej (wszechobecna gadatliwość, krzątanina w domach, hałas ulic i jarmarków). Niby jest to muzyka kreśląca obyczajowe pejzaże i serdeczne portrety ludzkie, lecz kiedy przysłuchać się uważniej, okazuje się, że często kontrapunktuje lub nawet zaprzecza widzianym na ekranie wypadkom przez swoje groteskowe przerysowanie albo zgoła metafilmowe zabiegi typu wyciemnianie kadru, mimo że wydarzenia toczą się dalej, wyciszanie dialogu, choć rozmawiający aktorzy pozostają widoczni na ekranie, albo mylenie tropów, które wątki muzyczne należą do sfery wewnątrzkadrowej,

${ }^{41}$ „W myśl koncepcji Claira obraz ma za zadanie przytłaczać dźwięk, przy czym fonia - i tu zasadnicze odstępstwo od poglądów Chaplina - winna odpłacać się pięknym za nadobne. Obie płaszczyzny filmowego spektaklu, po równo obdarzone impulsywnością, są świadomie skłócone i toczą ze sobą zaciętą walkę o dominację". T. Wojciechowski Dźwięk w kinie, cz. 4 - komedie René Claira, http://film.org. pl/a/artykul/dzwiek-w-filmie-cz-4-komedie-rene-claira-32764/ [dostęp: 1.01.16]. 
a które już nie ${ }^{42}$. Zaprzecza to opinii o „poczciwości” filmów Claira (który wszak w młodości był śmiałym awangardzistą, a zamiłowanie do przewrotnych wolt pozostało mu na zawsze), ale z drugiej strony stoi u źródła wrażenia, które Adam Garbicz, analizując klasyczne Pod dachami Paryża,

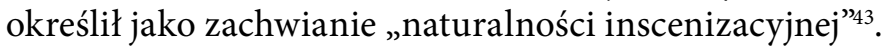

Właśnie z ową "naturalnością" zmagali się francuscy spadkobiercy Claira, np. reżyserzy Nouvelle Vague, którzy z jednej strony chcieli uchwycić samo życie w jego szorstkości i „niefilmowości”, ale z drugiej - brnęli w pozakadrowe, literackie komentarze, odczytywane nadto skrupulatnie „strumienie świadomości" bohatera. Jean Luc Godard wyreżyserował, oprócz kilku sztandarowych dzieł Nowej Fali w rodzaju Do utraty tchu, także paradoksalnie nowofalowy musical Kobieta jest kobietą, w którym aktorom zdarza się (pytanie: „naturalnie”, czyli jakby mimochodem, czy raczej „sztucznie”, z powodów artystycznych?) nucić motywy z muzyki pochodzącej ze sfery niediegetycznej, dobiegające ewidentnie spoza kadru. Niezależnie od odpowiedzi na to pytanie, Godardowi udało się przerzucić tym filmem co najmniej dwa efektowne pomosty. Jeden w przestrzeni: między awangardowym kinem europejskim a komercyjną amerykańską formą musicalu. Drugi zaś w czasie: między Pod dachami Paryża (1930) a Parasolkami z Cherbourga $(1964)^{44}$.

Na dylemat "naturalności” (wynikającej z filmowej prostoty podglądania ludzkich zachowań przez kamerę) i „sztuczności” (wynikającej z artystycznego aspektu kina, coraz bogatszego w środki formalne) warto spojrzeć z zewnątrz, spoza Europy i USA - czyli choćby z perspektywy Dalekiego Wschodu. Akira Kurosawa mówił o świadomym niedopełnieniu obrazu, pozostawieniu przez reżysera celowych luk, które ma zapełnić dźwięk, a ideę tę świetnie realizował Masaru Satô, współpracujący z nim przy tak

${ }^{42}$ „W scenie barowej bójki z Pod dachami Paryża grzmiąca z gramofonu uwertura do Wilhelma Tella Rossiniego powoduje konfuzję przyglądającego się starciu dwójki przyjaciół pijaka, który surrealistyczny obrazek uznaje za przejaw delirium. Zaskoczony dowcipem widz sam już nie wie, czy muzyka rzeczywiście dobiega $\mathrm{z}$ winylowej płyty, czy jest wytworem umysłu wstawionego jegomościa”. Ibidem.

${ }^{43}$ Pod dachami Paryża, [w:] A. Garbicz i J. Klinowski, op. cit., s. 171.

44 Film w reżyserii Jacquesa Demy z muzyką Michela Legranda, w którym wszystkie partie, nawet kwestie dialogowe, są śpiewane. 
znakomitych filmach, jak Ukryta forteca czy Straż przyboczna. Do jeszcze ciekawszych rezultatów doszedł Fumio Hayasaka, pracujący z reżyserem przy Siedmiu samurajach z 1954 roku. W filmie tym dźwięk wkracza znacznie śmielej w strukturę sceny, na pozór zaburza ją (np. gwałtowny rytm zakłócający kontemplację olśniewającej przyrody w scenie przed bitwą), ale $\mathrm{w}$ istocie poszerza jej panoramę, tyle że o elementy niewidoczne (rosnące przed walką napięcie $)^{45}$. W dodatku muzyczny komentarz zdaje się nadążać za chwilowymi zmianami akcji, ale tej synchronizacji ruchu wewnątrzkadrowego z muzyką (np. werblem kojarzącym się z biciem serca) bliżej do jazzowej improwizacji - która nie wyklucza przecież precyzyjnego zgrania instrumentów - niż do kontroli, jaką chciał uzyskać kilkanaście lat wcześniej Siergiej Eisenstein.

Montażowa skrupulatność - efekt wytężonych godzin współpracy Eisensteina z Prokofiewem - powoduje, że wiele scen z Aleksandra Newskiego sprawia wrażenie ożywiania czy też sklejania ze sobą „martwych” (przez swoje posłuszeństwo) wycinków rzeczywistości, przyszpilania motyli do maty. Mamy zatem w filmie rosyjskiego reżysera „ciąg rzutów przestrzennych" ${ }^{\text {"46 }}$ zamiast rozwijania się w czasie (dylemat, którego istotę ujmuje paradoks lecącej strzały, ukuty przez Zenona z Elei). Bardzo ta skrupulatność i kontrola irytowały Andrieja Tarkowskiego, który w jednym z tekstów krytycznych napisał, że: „u Eisensteina nie czuje się w poszczególnych ujęciach prawdy czasu - są one zupełnie statyczne i anemiczne. Wynika to oczywiście ze sprzeczności istniejącej między zewnętrzną zawartością ujęcia, która nie utrwala żadnego czasu, a szybkością postępowania po sobie całkowicie nienaturalnych połączeń - narzuconych z zewnątrz i obojętnych wobec płynącego w ujęciach czasu" ${ }^{\prime 47}$. Słowa te sporo mówią nie tylko o różnym u obu znakomitych reżyserów podejściu do materii filmowej, ale także o panującym w Związku Radzieckim ustroju, którego jednym z podstawowych elementów było pragnienie podporządkowania trywialnego życia

${ }^{45}$ Piotr Sawicki, Czas i energia. Kurosawa a muzyka, [w:] Akira Kurosawatwórca japoński, twórca światowy, red. W. Laskowska-Smoczyńska, P. Kletowski, Kraków 2011, s. 69.

${ }^{46}$ T. Wojciechowski, Dźwięk w kinie, cz. 6 - Aleksander Newski, http://film. org.pl/a/analiza/dzwiek-w-kinie-cz-5-aleksander-newski-36801/ [dostęp: 1.01.16].

47 Ibidem. 
wzniosłej idei, a także totalitarna kontrola najdrobniejszych nawet tegoż życia elementów.

Nie odnosząc się już bezpośrednio do Eisensteina, ale w ogóle do kina jako sztuki, Tarkowski daje wyraz podejściu bliskiemu Kurosawie, pisząc: „Prawdziwą muzykę kina tworzy starannie zorganizowany w filmie i muzyczny w swojej istocie świat dźwięków. [...] Dźwięki otaczającego nas świata są tak piękne, że jeśli nauczylibyśmy się ich słuchać z należytą uwagą, muzyka nie byłaby kinu potrzebna"48. Jeżeli przyjrzymy się różnicy w podejściu Hanekego do muzyki w Funny Games (gdzie jest użyta dość instrumentalnie, by zapowiedzieć wydarzenia, zwięźle scharakteryzować nawet nie postacie, ale psychologiczne typy bohaterów oraz ich status społeczny czy kulturowy) i w Miłości (gdzie towarzyszy bohaterom tak, jak towarzyszą im inne dźwięki powszedniej codzienności), możemy zaryzykować tezę, że Haneke przeszedł między tymi filmami drogę od Eisensteina do Tarkowskiego.

\section{JAK I O CZYM MÓWI MUZYKA W FILMACH HANEKEGO}

„Panicznie boję się przemocy fizycznej, chociaż nigdy nie zostałem nawet uderzony" - powiedział Haneke w dokumentalnym filmie 24 rzeczywistości na sekundę $e^{49}$. W innym dokumencie, Michael Haneke: Moje życie, aktorka Juliette Binoche jednym tchem wymienia kolejne obsesyjne lęki reżysera: „Śmierć, choroba, cierpienie, strach przed odrzuceniem, byciem niedostrzeganym, niesłyszanym" ${ }^{50}$. Z drugiej strony, mamy wspomnienie austriackiego reżysera o oglądanym na studiach Tomie Jonesie Tony'ego Richardsona i metafilmowym geście bohatera - niespodziewanym odwróceniu się wprost do kamery, by powiedzieć „Mam nadzieję, że mnie nie złapią” - który wstrząsnął Hanekem i był, według słów reżysera: „totalnym

48 A. Tarkowski, Czas utrwalony, tłum. S. Kuśmierczyk, Warszawa 2007.

4924 Realities per Second: A Documentary on Michael Haneke, reż. N. Kusturica i E. Testor, [cyt. za:] M. Sadowska, Michael Haneke: cichy włamywacz, „Newsweek” z dnia 31.10.2012 r., www.newsweek.pl/kultura/film/michael-haneke--cichy-wlamywacz,97712,1,1.html [dostęp: 30.05.16].

50 Michael Haneke: My life, reż. Felix i Gero von Boehm, [cyt. za:] M. Sadowska, op. cit. 
odczarowaniem, pozwalającym zrozumieć, czym jest iluzja"51 . Warto wspomnieć, że podobne traumatyczne wspomnienia są udziałem Elfriede Jelinek, autorki powieści Pianistka, która w wywiadzie dla „Teleramy” wyznała: "Zaczęłam uczyć się gry na pianinie, mając lat siedem, później doszły jeszcze skrzypce. To była destrukcja mojej młodości i mojego życia. Bo kiedy traci się młodość, to na całe życie"52.

Powyższe konteksty pozwalają przypuszczać, że powtarzane jak mantra w recenzjach filmów Hanekego określenie "gra z widzem”"53 (oznaczające tyleż grę z masowymi oczekiwaniami publiczności, co w ogóle z kulturą popularną i jej regułami), dotyczy gry, którą reżyser prowadzi także - a może: przede wszystkim - sam ze sobą. Nie chodzi jednak o to, by tą drogą dojść do wniosku, że Haneke funduje sobie autoterapię (w Funny Games przez skonfrontowanie własnego „panicznego lęku” z przemocą czystą, manichejskim Złem, w Pianistce poprzez swoisty seans sadomasochistyczny, zaś w Miłości przez bezpośredni kontakt ze śmiercią), albo że dokonuje osobistej zemsty za własne „odczarowanie” (nagłe zwrócenie się z pytaniem w stronę widza czy też metafilmowe cofnięcie taśmy przez jednego z oprawców w Funny Games to oczywiście ponure echa gestu Toma Jonesa).

Stawka wydaje się większa niż jedno - nawet tak ważne, bo reżyserskie - życie. Mało zabawne "games” uprawiane przez Hanekego, igraszki z diabłem traum i lęków, są nie tylko dalekie od chwytów znanych z kinowego mainstreamu ${ }^{54}$, ale także od czysto formalnego filmowego ekspery-

${ }^{51} 24$ Realities per Second..., [cyt. za:] M. Sadowska, op. cit.

52 Cyt. za: G. Arata, Dla Isabelle, „Kino” 2011, nr 11.

53 „Gra, którą Paul i Peter prowadzą z zastraszoną rodziną, nie jest jedyną rozgrywką w filmie, a wręcz jest znacznie mniej istotna niż gra, którą reżyser prowadzi $\mathrm{z}$ widzem. Niemal przez cały czas trwania projekcji zadaje jedno, proste pytanie: »Po co to oglądasz?«. Wie doskonale, czego oczekuje publiczność, i wykorzystuje tę wiedzę, by irytować, manipulować odbiorcą, a w konsekwencji spróbować zmusić go do zastanowienia się nad samym sobą. [...] Haneke walczy nie tyle z ramą gatunku, w którym się porusza, czyli thrillerem, a raczej z tym, czego oczekuje od niego widz". J. Dudkiewicz, op. cit.

54 „Większość reżyserów próbuje w swoich filmach osiągnąć mniej więcej te same cele: zdiagnozować pewien problem, odpowiedzieć na pytania »dlaczego tak jest« i »jak z tej sytuacji wyjśćc, wreszcie z sympatii do własnych bohaterów 
mentu (choć przy okazji dochodzi tu do postmodernistycznego zamachu na świętość gatunków filmowych, np. kryminalnego thrillera w Funny Games czy melodramatu w Pianistce). Wkraczamy zatem do swoistego kinowego laboratorium, czy może do pokoju kolekcjonera z przyszpilonymi egzemplarzami - nosicielami ludzkich przypadłości. Pytanie, jak uruchomić filmową narrację, której korzenie sięgną głębiej niż oko kamery, zaś ramy będą szersze niż filmowy kadr? Jak wnieść żywą historię do gabinetu figur wymodelowanych do przesady ostro i wyraziście?55

W tym miejscu rozważań musi pojawić się kwestia swoistego programowania czy modelowania aktorów. W analizach filmów austriackiego reżysera pojawia się wątek pokrewieństwa modeli aktorskich u Michaela Hanekego i Roberta Bressona ${ }^{56}$ (choć istnieje zasadnicza różnica: Bresson pracował z naturszczykami, a Haneke czyni to $z$ wytrawnymi zawodowcami ${ }^{57}$ ). Obaj reżyserzy zgadzają się co do kwestii życia wewnętrznego swoich bohaterów (Bresson: „Żadnej psychologii”; Haneke: „Nie uważam psychologii za czynnik konieczny"), i w tym kontekście należy odebrać pochwalną ocenę austriackiego reżysera skierowaną pod adresem jego protagonistki, Isabelle

okazać im litość i zafundować happy end lub przynajmniej nadzieję na lepsze życie. Słowem: dać oglądającemu widzowi poczucie katharsis, oczyścić atmosferę tak, aby po wyjściu z kina poczuł się on wzbogacony o nowe doświadczenie. [...] Michael Haneke jest inny”. Blog „Filmowe konkret-słowo”, https://xmuza.wordpress.com/2012/06/11/la-pianiste-2001-michael-haneke [dostęp: 25.04.15].

55 „Klauni-kaci z Funny Games są równie sterylni w swoich białych rękawiczkach, jak Erika, tytułowa Pianistka, w swoim przeżywaniu seksualności, zdominowanym przez jej wyobrażenie cudzych fantazji i przez wymiary pożądania zwykle umieszczane bezpiecznie w dziale "pornografia«". I. Kurz, Potworność. O Michaelu Hanekem, „Dwutygodnik” 2012, nr 11/96, www.dwutygodnik.com/ artykul/4135-potwornosc-o-michaelu-hanekem.html [dostęp: 25.04.15].

${ }^{56}$ „W podejściu do aktorstwa Hanekemu z pewnością najbliżej do Bressona i jego automatycznych modeli, wypranych z uczuć". J. Topolski, 27 fragmentów socjologii przypadku: haneke, „Odra” 2010, nr 1.

${ }^{57}$ „Przypomina się imperatyw Bressona: Być (modele) zamiast pozorować (aktorzy). Paradoks polega na tym, że Hanekemu udaje się uzyskać za sprawą profesjonalnych aktorów efekt, który Bresson osiągał, »używając « aktorów niezawodowych, czyli »modeli«”. P. Zawojski Przypisy do „Ukrytego" Michaela Hanekego, „Opcje” 2006, nr 4. 
Hupert: „potrafi ona zagrać wszystko, nie angażując uczucia, tylko je genialnie naśladując". Jeżeli do takich słów artysty (jakże ambarasujących: aktorstwo jako mimikra?, gdzie Stanisławski?, gdzie Grotowski?, gdzie Lee Strasberg i Metoda?) dodamy opinię jednego z recenzentów jego sztuki zgodnie z którą „kamera patrzy na bohaterów okiem mądrego patologa” 58 - siłą rzeczy wypada zadać pytanie o życie w filmach Michaela Hanekego.

\subsection{MUZYKA PO PRZEJŚCIACH, AKTORZY Z PRZESZŁOŚCIĄ}

Funny Games pod wieloma względami ogląda się jeszcze jak „wczesnego Hanekego": precyzyjnie skonstruowany filmowy mechanizm, zaprogramowany na osiągnięcie konkretnych efektów ${ }^{59}$, oraz ścisła kontrola nad widzem i jego emocjami ${ }^{60}$. Wykonawcy głównych ról (Susanne Lothar i Ulrich Mühe jako sterroryzowane małżeństwo, a także Arno Frish i Frank Giering jako ich prześladowcy) to niewątpliwie aktorzy warsztatowo znakomici, ale względnie młodzi i znani z kina niemieckiego, a więc niekojarzeni z międzynarodowym kanonem filmowym. Ścieżka dźwiękowa do filmu prezentuje się równie skromnie, towarzyszy jedynie napisom początkowym i na pozór wygląda jedynie na wprowadzenie w fabularną sytuację (ale - o czym napiszę dalej - nawet tych kilka niepozornych minut, $\mathrm{z}$ utworami trafiającymi do nieprzygotowanego, dopiero moszczącego się w kinowym fotelu widza, okazuje się dla filmu niezwykle istotne).

Inaczej jest w filmach Pianistka i Miłość, które w sferze znaczeń znacznie dalej wykraczają poza obszar prostych interpretacji i odpowiedzi na pytanie „co artysta miał na myśli?”61. W Pianistce tytułową rolę gra francuska

58 T. Sobolewski, Ból wolności - ekranizacja „Pianistki”, http://wiadomosci. gazeta.pl/wiadomosci/1,114873,2328011.html [dostęp: 30.05.16].

59 „Haneke używa Paula i Petera (w pewnym sensie swoich przedstawicieli, pomagających mu w kontakcie z publicznością), by pokazać, że ludzie chcą oglądać takich bohaterów". J. Dudkiewicz, op. cit.

${ }^{60}$ „Haneke. Ten facet wie, gdzie bić. Manipuluje, prowadzi widza wydeptaną ścieżką na rzeź, pokazuje mu środkowy palec". D. Arest, Haneke: Not so funny, „Gazeta Wyborcza”, http://wyborcza.pl/1,76842,5547054,Haneke__Not_so_funny. html\#ixzz45QDzJu8w [dostęp: 1.04.16].

61 „Doceniając wszystkie wcześniejsze filmy Michaela Hanekego, zżymałem się niekiedy na wyraziście stawiane przezeń tezy, formułowane w stylu tak 
aktorka Isabelle Huppert, znana od początku lat 70. z występów u najsłynniejszych reżyserów (jak Jean-Luc Godard, Michael Cimino, James Losey) i szczególnie ceniona za sugestywne kreacje bohaterek skrajnie wrażliwych, których uwikłanie w dramaty kobiecości wiąże się z realiami społecznymi i obyczajowymi (np. w filmach Koronczarka Claude'a Goretty czy Pani Bovary Claude’a Chabrola). Z kolei w Miłości wystąpił duet aktorów, których można nazwać - bez nadużywanej często egzaltowanej przesady - legendami kina $^{62}$. Emmanuelle Riva zasłynęła debiutancką rolą w filmie Hirosima, moja miłość Alana Resnais'go, uznawanym za jeden z najważniejszych filmów $\mathrm{w}$ historii kina. Jego awangardowa forma jest nie tylko eksperymentem artystycznym, ale zarazem rodzajem wyzwania rzuconego mieszczańskim stereotypom lat 50. ubiegłego stulecia i równie skostniałej narracji historycznej. Natomiast Jean-Louis Trintignant to jeden $z$ kanonicznych kinowych amantów (sztandarowa rola w filmie Kobieta i mężczyzna Claude'a Leloucha), znany jednak również z filmów, których kulturowy wymiar jest znacznie szerszy, zarówno pod względem społeczno-obyczajowym (I Bóg stworzyt kobietę Jeana-Luca Godarda, Konformista Bernardo Bertolucciego) czy psychologicznym (Trzy kolory: Czerwony Krzysztofa Kieślowskiego), jak i czysto artystycznym (Pustynia Tatarów Valerio Zurliniego).

Cała trójka aktorów niejako „w pakiecie” wnosi do filmów, w których gra, nie tylko historię kina czy w ogóle historię kultury z jej przemianami i konfliktami, ale także zaufanie widza, zdobyte już wcześniej dzięki wielowymiarowości kreowanych przez nich postaci ${ }^{63}$. W tym kontekście godne

gwałtownym, że właściwie niedopuszczającym odrębnego zdania. W Miłości reżyser stępił pazur doktrynera”. Ł. Maciejewski, Miłość to bohaterstwo przez rezygnację, http://film.dziennik.pl/recenzje/artykuly/409314,milosc-to-bohaterstwo-przez-rezygnacje.html [dostęp: 1.04.16].

${ }^{62}{ } \mathrm{Na}$ ekranie dwie legendy francuskiego kina - Emmanuelle Riva, młoda kochanka z Hiroshimy, mojej miłości Alaina Resnais'go, oraz Jean-Louis Trintignant, który dla Hanekego po kilkunastu latach przerwy wraca do kina". M. Grochowska, Miłość ponad wszystko, www.filmweb.pl/reviews/ Mi\%C5\%82o\%C5\%9B\%C4\%87+ponad+wszystko-12843 [dostęp: 1.04.16].

63 „To rezultat postawienia przed kamerę wykonawców tak wiarygodnych jak Riva i Trintignant. U których możemy ujrzeć aktorską maestrię, a w grze Rivy być może nawet kobietę potrafiącą unieść całą emocjonalną siłę Hiroszimy, mojej miłości 
uwagi jest upodobanie austriackiego reżysera do tych samych imion (w produkcjach niemieckich: Anna i Georg, w produkcjach francuskich: Anne i Georges) nadawanych parom głównych bohaterów w różnych filmach. Nie chodzi o to, że coś łączy filmowe historie, chodzi o sugestię, że ich bohaterowie zachowują pewną ciągłość charakterologiczną oraz zbierany film za filmem (paradoksalnie, bo - jak wiadomo - u Hanekego nie z każdego filmu „da się ujść z życiem”) bagaż doświadczeń. Swoiste „podwójne życia” Anny i Jerzego pozwalają im podejmować różne wybory, zmieniać pewne cechy charakteru, ale w obrębie pewnej kulturowo określonej tożsamości dla widza rozpoznawalnej i wiarygodnej. W Funny Games Anna i Georg są melomanami znającymi na wyrywki muzyczną klasykę, włącznie z konkretnymi wykonaniami utworów, ale zawodowo zajmują się czymś innym; natomiast w Miłości (2011) Anne i Georges są nauczycielami muzyki, a Anne wychowuje nawet prawdziwych wirtuozów. W Siódmym kontynencie z 1989 roku Anna i Georg zamykają się przed światem na cztery spusty, by popełnić wstrząsające rodzinne samobójstwo, natomiast Anne i Georges z Miłości równie zgodnie izolują się $\mathrm{w}$ mieszkaniu, by razem walczyć $\mathrm{z}$ nieuleczalną chorobą kobiety ${ }^{64}$.

Podobnie u Hanekego rzecz ma się z muzyką, tym bardziej że reżyser wykorzystuje w swoich filmach głównie utwory skomponowane w XVIII i XIX wieku, a następnie wielokrotnie reinterpretowane (zgodnie ze zmieniającymi się kanonami), a zatem głęboko zanurzone w kulturowej i społecznej rzeczywistości. Poza tym Austriak pozostaje wierny kompozytorom z bliskiego sobie kręgu, szczególnie Franzowi Schubertowi i Ludwigowi van Beethovenowi (obaj dużą część życia spędzili w Wiedniu), do których

Alaina Resnais'go”. R. Gilbey, „Amour” and the Music of Time, www.newstatesman. com/culture/2012/11/michael-hanekes-amour-and-music-time [dostęp: 30.05.16].

64 „Ta cicha aprobata nie nosi jednak znamion ostentacji, wydaje się naturalnym przedłużeniem małżeńskiego doświadczenia Anne i Goerges’a. Ich wspólnej przeszłości Haneke nigdy co prawda nie opowiada, sugeruje ją jednak na płaszczyźnie pozafabularnej - głównych bohaterów grają tu legendy francuskiego kina, a ich poprzednie ekranowe wcielenia ciągle żyją w pamięci widza; w pewnym sensie dopowiadają widzowi, co mogło się dziać między tą dwójką w minionych latach". G. Fortuna, Delikatność, http://film.org.pl/r/recenzje/milosc-17041/ [dostęp: 30.05.16]. 
można dodać także obecnych nie tyle poprzez konkretne kompozycje, co raczej „duchem” - Roberta Schumanna czy Fryderyka Chopina. Wszyscy ci kompozytorzy funkcjonują w kulturowej pamięci tyleż dzięki swoim utworom, ile poprzez biografie, w których burzliwe fakty i niedyskretne domysły zrosły się na prawach wciąż budzącego emocje mitu. Można zatem powiedzieć, że w Pianistce i Miłości „aktorom z przeszłością” towarzyszy „muzyka po przejściach”.

Umiejętny dobór muzyki sprawia, że narracja w filmach Hanekego uruchamia się niejako sama ${ }^{65}$, a historię zastajemy już rozpoczętą, dziejącą się $^{66}$, rozpędzoną na tyle, że reżyser nie musi (ach!, jakże by tego nie chciał) niczego tłumaczyć ${ }^{67}$. Wyjątkowo efektownie udaje się to w czołówce Funny Games - z rodziną słuchającą kompozycji z samochodowego odtwarzacza. Ledwie przemkną napisy początkowe, widz wie już całkiem sporo nie tylko o bohaterach i ich statecznym, dostatnim żywocie, ale także o kruchości tej sielanki (wystarczy zmienić radiowy kanał czy płytę); nie tylko o przeszłości (nie tyle osobistej, ile kulturowej), ale także o przyszłych wydarzeniach; nie tylko o nagich faktach, ale także o symbolicznym porządku, w którym te fakty są zanurzone. Każde zanurzenie powoduje - co wiadomo od czasów

65 „Całą historię Funny Games skraca czołówka. Rodzinka jedzie samochodem i bawi się w operowe zagadki. Słyszymy Mozarta, Pucciniego, Macagniego. Za oknem sielskie pejzaże. Nagle wybucha heavy metal. I tytuł na czerwonym tle. To zespół Naked City, na saksofonie drze się John Zorn. Oczywiście nie chodzi o banalne przeciwstawienie mieszczaństwa i agresji, lecz o efekt trzęsienia i thrillu”. J. Topolski, 27 fragmentów..., op. cit.

66 „Sam Haneke jest muzycznym erudytą, co wykazał, kompilując utwory do kolejnego filmu. Stłamszona przez matkę i pognębiona przez system Klavierspielerin (tytuł oryginalny) musi pracować jako Piano Teacher (angielski tytuł książki). Świątynia tradycji, konserwatorium, okazuje się piekłem na ziemi, pełnym frustratów i Przegranych (Bernhard). Jak aktualnie brzmi tu spór między klasyką a moderną, czyli hierarchiczną tonalnością a swobodną atonalnością". Ibidem.

67 „Lojalnie uprzedzałem, że nie odpowiem na żadne pytanie, które dotyczyć będzie interpretacji moich filmów". Wrzątek podany na zimno [z Michaelem Hanekem rozmawia Paweł Felis], „Gazeta Wyborcza”, http://wyborcza.pl/piatekekstra/1,129155,14799325,Wrzatek_podany_na_zimno.html [dostęp: 30.05.16]. 
Archimedesa - efekt wyparcia, i być może właśnie o tym, co wyparte, jest cała reszta filmu.

\section{FUNNY GAMES, CZYLI MUZYKA JAKO TOWARZYSTWO UBEZPIECZENIOWE}

Czego zatem słuchają Anna i Georg, bohaterowie Funny Games, czyli małżeństwo jadące wraz z synem Schorsim na swoją działkę nad jeziorem? $\mathrm{Z}$ odtwarzacza płyną najklasyczniejsze $\mathrm{z}$ klasycznych operowe arie: wystawnie barokowa Care selve z opery Atalanta Georga Friedricha Haendla oraz zorkiestrowana na bujną XIX-wieczną modłę Tu qui santuzza z opery Rycerskość wieśniacza Pietro Mascagniego ${ }^{68}$. Pomiędzy kwiecistym patosem Haendla a postromantyczną manierą Mascagniego lokuje się - słyszany w filmie przez moment - utwór nieco skromniejszy w wyrazie: Kwintet klarnetowy A-dur Wolfganga Amadeusza Mozarta, którego wyrafinowana melodyka także nawiązuje do operowej tradycji śpiewaczej ${ }^{69}$ i całej związanej z nią historii europejskiej sztuki.

Oczywiście, jeżeli przyjrzymy się dokładniej muzyce Haendla i Mascagniego (a można założyć, że uprawiający swoje „zabawne gry” w zagadki Anna i Georg mają sporą wiedzę na ten temat), to znajdziemy w nich dużo więcej niż estetyczny urok. Stosunkowo mniej znany, poza środowiskiem wielbicieli oper, Pietro Mascagni jest uznawany za jednego z pierwszych przedstawicieli tak zwanego weryzmu, czyli kierunku w sztuce przełomu XIX i XX wieku, który był kontynuacją naturalizmu i dążył do ukazywania, w „naturalnym” stanie, rzeczywistości społecznej z towarzyszącymi jej napięciami i problemami. Po pierwsze jednak, ciążyła na włoskim kompozytorze, tak jak na wielu innych kompozytorach uprawiających weryzm (można do nich zaliczyć także autora Halki, Stanisława Moniuszkę), pewna powierzchowność oraz skłonność do protekcjonalizmu, z jakim artysta pochyla się ze swoich wyżyn nad losem „prostego ludu”. Po drugie, weryzm u Mascagniego był dość powierzchowny i dotyczył raczej

68 „Rycerskość wieśniacza błyskawicznie stała się przebojem sal operowych całego świata”. M. Rye, 1001 albumów muzyki klasycznej, tłum. A. Fulińska, Poznań 2003, s. 460

${ }^{69}$ „Mozart w pełni wykorzystał aksamitne brzmienie klarnetu [...], pisząc na ten instrument długie, przypominające arie melodie”. Ibidem, s. 180. 
zawartości libretta niż struktury kompozycji, która nie wykraczała poza gatunkowe schematy z poprzedniej epoki muzycznej i miała zdecydowanie inne ambicje niż uchwycenie jakiegokolwiek społecznego realizmu ${ }^{70}$. Po trzecie wreszcie, opera Mascagniego miała nieszczęście do ogromnej liczby wykonań epatujących stereotypowym wdziękiem „przebojów muzyki klasycznej"71, co ma znaczenie dla jej usytuowania na symbolicznej mapie kultury.

Wynika z tego, że rodzinnym samochodem jadą spadkobiercy trzech stuleci kultury europejskiej, a gdyby przyjrzeć się im uważnie (drogie auto holujące przyczepkę z jachtem, które zmierza ku działce $\mathrm{z}$ domem nad górskim jeziorem) i bardziej krytycznie, można by rzec, że to beneficjanci burżuazyjnej kultury konsumpcji i społecznej zachowawczości. Ich muzyczna erudycja (małżonkowie grają w zagadki dotyczące wykonań poszczególnych utworów) nie zmienia faktu, że poruszają się po bezpiecznym terenie sztuki oswojonej do granic banału i że taka sztuka pełni dla nich rolę estetycznego przewodnika.

Owa gra w muzyczne zagadki podsuwa jedną z kilku możliwych interpretacji tytułu filmu. Zabawa przebiega w atmosferze wesołych przepychanek słownych i obrazuje sielankę serdecznej rodzinności połączoną z ekonomicznym dobrostanem. Właśnie wtedy jednak następuje moment przełomowy: jakby czyjaś ręka zmieniła utwór w odtwarzaczu, raptem z głośników uderza kakofoniczny zgiełk utworu Bonehead zespołu Naked City, zawieszony pomiędzy heavy metalem, muzyką noise i free-jazzem. Wejście tej muzyki jest tak nagłe i gwałtowne, jakby było fizycznym uderzeniem, ale jej wymiar jest znacznie głębszy niż dźwiękowa agresja.

70 „U Mascagniego realistyczne dążenia przejawiają się niemal wyłącznie w treści i w charakterze dramatycznej akcji; od strony muzycznej bowiem utrzymuje się na ogół Rycerskosśc wieśniacza w tradycyjnych konwencjach włoskiej opery”. J. Kański, Przewodnik operowy, Kraków 1985, s. 203.

${ }^{71}$ „Być może był to lepszy kompozytor, niż się to dziś powszechnie uważa: jego najbardziej popularna opera Rycerskość wieśniacza obciążona jest rzeczywiście dosyć powierzchownymi tradycjami wykonawczymi i chętnie się ją wskazuje jako przykład marnego gustu i operowej sztampy". J. Łętowski, Muzyka klasyczna na płytach kompaktowych, Warszawa 1997, s. 136-137. 
Liderem grupy Naked City jest saksofonista John Zorn, eksplorujący cały obszar muzyki współczesnej, bez podziału na style i gatunki ${ }^{72}$, a w kilku projektach, którymi kieruje (m.in. w grupie Masada), podkreślający także własne żydowskie pochodzenie (rzecz jasna, z jego bagażem historycznym). Trudno w takim kontekście zadowolić się prostą interpretacją, że nawet jeżeli nie chodzi tu o „przeciwstawienie mieszczaństwa i agresji”, to po prostu o efekt „trzęsienia i thrillu”" Z Zestawienie radykalnej artystycznej filozofii Zorna (synteza rozmaitych wątków muzycznej tradycji i skrajnie nowoczesnych środków wyrazu) z dość sztampowymi „przebojami muzyki klasycznej" (symbolizującymi określony ład panujący w Europie od kilku stuleci) może sugerować kolizję uporządkowanej egzystencji pod medialno-konsumenckim kloszem - z inną rzeczywistością, obnażoną niczym miasto w nazwie zespołu Zorna. Pojawiająca się za sprawą muzyki rysa - zarówno na społeczno-ekonomicznym fundamencie Europy, jak i na tożsamości jej mieszkańców, ufundowanej przez racjonalny gest Kartezjusza - w dalszych scenach filmu zmieni się w rujnujące pęknięcie.

Gwałtowne zmiany nastroju i „kierunku” muzycznej narracji są zresztą jedną z zasadniczych cech twórczości Zorna. Muzyk powołuje się tu na inspirację motywami Carla Stallinga, komponowanymi do popularnych kreskówek z serii „Zwariowane melodie” ze studia Warner Bros (ich bohaterowie to m.in. Królik Bugs, Kaczor Duffy, Struś Pędziwiatr). Te animowane filmiki swoją niesamowitą witalność, narracyjną jędrność i ponadczasowy humor zawdzięczają w dużej mierze muzyce Stallinga, opartej na skrajnych kontrastach tempa i dynamiki. Zostały one gładko przyswojone przez kulturę masową jeszcze w pierwszej połowie XX wieku, ponieważ pasowały do groteskowego, pełnego czarnego humoru świata kreskówek. Przewrotność stylistyczna nie była zresztą dla Stallinga celem samym w sobie, a tylko środkiem do jego osiągnięcia, ponieważ wszystko zaczęło się od tego, że na potrzeby szybkiej, przemysłowej produkcji kompozytor wymyślił

72 „Mój świat muzyczny jest jak niewielki pryzmat. Patrzysz przezeń, a on rozprasza się ku milionom różnorodnych kierunków. Ponieważ każdy gatunek muzyki jest tym samym, wszyscy muzycy zasługują na jednakowy szacunek". Słowa Johna Zorna, [cyt. za:] K. Niweliński, Zorn, John - Naked City, http://artrock.pl/ recenzje/51397/zorn_john_naked_city.html [dostęp: 30.05.16].

73 J. Topolski, 27 fragmentów..., op. cit. 
urządzenie pozwalające zmieniać tempo nagrania w trakcie montażu filmu (aby rysownicy i muzycy mogli pracować niezależnie). Zorn, inspirując się kompozycjami Stallinga, przenosi jego - jak to ujął dziennikarz magazynu „Rolling Stone” - „zawracające z piskiem opon schizofreniczne motywy”74 z bezpiecznej krainy animowanej groteski w świat niebezpiecznie bliski ludzkiej codzienności. Pokazuje, jak dobrze pasują do otaczającego nas mechanicznego zgiełku oraz informacyjnego chaosu.

W gwałtownym zwrocie akcji muzycznej na początku Funny Games możemy zatem doświadczyć, jak z gruntu filmowa technika kompozytorska - która najpierw została przez Zorna „wyniesiona” poza obszar kina, a potem „przywrócona” przez Hanekego tam, skąd się pierwotnie wzięła ujawnia swój głębszy aspekt, czyli zmienia muzykę w swoisty „komentarz socjologiczny".

Sam Haneke, zapytany bezpośrednio o muzykę Johna Zorna, kieruje nas ku jeszcze innemu - parodystycznemu, ironicznemu - kontekstowi twórczości tego artysty (według Hanekego, okazuje się on rodzajem „nad-heavymetalowca”, z całym nietzscheańskim bagażem tego neologizmu), której „przeakcentowanie”, hałaśliwe „przeegzaltowanie”, odpowiada formie Funny Games jako ekstremalnie przesadzonego thrillera ${ }^{75}$. Wykorzystane w filmie utwory Zorna są zresztą opatrzone tytułami, w których można się dopatrywać ironii czy pastiszu heavymetalowej konwencji (Bonehead, Hellraiser). Pamiętając o namaszczonej powadze, z jaką kultura mieszczańska celebruje muzykę klasyczną - a według Hanekego, wręcz ją zawłaszcza, uzurpując sobie przesadne zasługi w historii kultury ${ }^{76}$ - możemy usłyszeć w muzyce Zorna dźwięk siarczystego policzka wymierzanego „sytym burżujom”.

${ }^{74}$ www.rollingstone.com/music/lists/the-100-greatest-metal-albums-of-all-time-w486923/naked-city-torture-garden-1990-w487068 [dostęp: 30.05.16].

75 „Odbieram Johna Zorna jako rodzaj nad-heavy metalu [über-heavy metal], ironiczne przeakcentowanie pewnej formy, która - jako film - staje się ekstremalnie przegiętą odmianą thrillera". The World That Is Known [Michael Haneke w rozmowie z Christopherem Sharrettem], www.kinoeye.org/04/01/interview01.php [dostęp: 30.05.16].

76 „Oczywiście, trudno nie patrzeć ironicznie na to, jak mieszczaństwo sytuuje samo siebie w historii kultury”. Ibidem. 
Jeżeli przyjrzymy się uważnie początkowej sekwencji filmu, widzimy jednak, że utwór Johna Zorna - w przeciwieństwie do Mascagniego i Haendla - nie mieści się w sferze diegetycznej (czyli słyszy go tylko widz, nie bohaterowie), tak samo jak niekoniecznie mieści się w ekranowej diegesis kilka późniejszych działań dwójki morderców (pytania kierowane bezpośrednio do widza czy cofnięcie akcji filmu za pomocą telewizyjnego pilota). A skoro rodzina nie posłuchała pierwszego wezwania do opamiętania się, reżyser wysyła im drugie upomnienie - w postaci dwójki morderców. Ironia Michaela Hanekego okazuje się - wbrew „moralistycznym” pozorom - podobna do ironii Quentina Tarantino, który także nie waha się „argumentować” za pomocą ludzkich zwłok.

Jeżeli potraktujemy początkowe, wzbogacone muzyką sekwencje Funny Games jako swoistą uwerturę do filmu - pamiętając, że od XVIII wieku uwertura zawierała krótkie motywy wzięte z następującej po niej opery, dzięki czemu miała wprowadzać w atmosferę zasadniczego dzieła - widzimy, że to, co w skrótowej formie dzieje się przez pierwsze kilka minut filmu, potem rozegra się raz jeszcze, już w pełnym, półtoragodzinnym wymiarze. „Uwerturowy” charakter wstępnej, opatrzonej muzyką części filmu pozwala zadać pytanie, na ile cała jego reszta jest realistyczna (nawet jeśli miałby to być folderowy weryzm jak z Mascagniego), a na ile bezceremonialnie "operowa” (a wtedy wystudiowaną brutalność filmu można skojarzyć z brutalnością rodem z westernowych „końskich oper” Sergio Leone)? Sztucznie przerysowane - zarówno pod względem stroju, jak i zachowania - postacie dwójki morderców, ujrzane w kontekście „operowym” okażą się jak najbardziej na miejscu. Zaś ich dialogi - rozpisane niczym arie, w których chodzi raczej o harmonie czy kontrasty niż o realny sens napędzający akcję - zaczniemy podejrzewać o celowe kwestionowanie realizmu filmu (tak jak kwestionują ów realizm kunsztownie absurdalne dialogi pary morderców, Vincenta i Julesa, z Pulp Fiction Tarantino).

Potwierdzenie intencji zamachu na realistyczność filmowej rzeczywistości Funny Games przychodzi z przeciwległego krańca filmu, kiedy w jednej z końcowych scen, na łódce, tuż przed zabójstwem ostatniej ze swoich ofiar, psychopatyczni agresorzy toczą ze sobą znamienną rozmowę:

Paul: Czyż fikcja nie jest realna?

Peter: Dlaczego? 
Paul: No przecież widzisz ją w filmie, prawda?

Peter: Oczywiście!

Można spojrzeć na ten dialog z kilku perspektyw. Po pierwsze, jako na gorzki metafilmowy żart Hanekego ${ }^{77}$, który przez cały czas gra $\mathrm{z}$ konwencjami filmowymi (sensacyjnego thrillera o bandyckim napadzie, horroru - z zagęszczającą się atmosferą prowadzącą do nieuniknionej masakry, ale także filmu dokumentalnego czy programu w konwencji reality, gdzie w nudny, skrupulatny sposób analizuje się przebieg zbrodniczych wydarzeń $^{78}$ ), i w tym momencie rozmowa daje do zrozumienia, że jako widzowie ulegamy regułom medialnego spektaklu w momencie kontaktu $\mathrm{z}$ nim, skoro przekaźnik - zgodnie ze słynną maksymą Marshalla McLuhana - sam w sobie jest przekazem. Istotny przy tym okazuje się podział dokonany przez Kanadyjczyka: na media „gorące” (które łatwiej zawłaszczają i kontrolują emocje odbiorcy) i „zimne” (które nie mają mocy, by uczynić to samodzielnie). McLuhan bowiem zalicza film do mediów "gorących” - łączących się z ludzkimi zmysłami z „wysoką rozdzielczością” (czyli tak, jak robi to rzeczywistość pozafilmowa). Według McLuhana: „oddziaływanie techniki nie ujawnia się na poziomie opinii lub koncepcji, ale trwale, nie napotykając na żaden opór, zmienia proporcje zmysłów lub wzorce percepcji"79.

Ten kontekst pozwala jeszcze śmielej interpretować absurdalny dialog morderców, ponieważ w takim samym jak kino złudzeniu „realności” utrzymuje mieszkańca cywilizacji tak zwanego Zachodu jej obraz tworzony przez kulturę (nie tylko tę masową - sugeruje reżyser za pośrednictwem prezentowanego na wstępie Haendla czy Mozarta). Dobrze pokazuje ów stan zarówno początek filmu (rodzinny samochód jest wysokiej klasy, wygląda na zaopatrzony w zabezpieczenia typu poduszki powietrzne czy system ABS),

77 „Film antygatunkowy, parodia. Akcja toczy się jak akcja thrillera, ma strukturę thrillera, ale w tym samym czasie film komentuje sam siebie". Michael Haneke $\mathrm{w}$ rozmowie $\mathrm{z}$ Sergem Toubianą, $\mathrm{www} . y 0 u$ ube.com/watch?gl=PL\&hl=pl\&v=roOl9PvEPjs [dostęp: 30.05.16].

78 Przykładem może być magazyn kryminalny 997 emitowany w Telewizji Polskiej od 1986 do 2010 roku i cieszący się przez te dwadzieścia cztery lata dużą popularnością.

79 Zob. M. McLuhan, Zrozumieć media: Przedłużenia człowieka, tłum. N. Szczucka-Kubisz, Warszawa 2004. 
jak i sposób, w jaki reżyser rozwija akcję, co chwila dając widzowi nadzieję, że bohaterowie wywiną się z opresji - korzystając przy tym ze schematów, na których opiera się kino gatunkowe. Bohaterowie także wierzą w swoje bezpieczeństwo, bo wierzą w trwałość i szczelność struktury, w jakiej się wychowali - czyli w tę kulturę, której symbolem i szczytowym osiągnięciem jest muzyka Haendla czy Mozarta.

Podobnie dzieje się z widzem: wierzy w możliwość uratowania bohaterów z rąk psychopatycznej pary, bo wierzy w strukturę filmowej konwencji, a szerzej - w strukturę kultury, jaka go otacza. W jej - jak to metaforycznie ujął Peter Sloterdijk - „kryształowy pałac”, który zyskał ostatnio nowy wymiar: globalizację ${ }^{80}$. Dzięki filmowej konwencji nawet w najkrwawszych horrorach zazwyczaj jednemu z bohaterów udaje się ujść z życiem (w tym przypadku byłaby to Anna, która na łódce podejmuje ostatnią próbę ocalenia - ale reżyser przecina i tę nitkę nadziei). Konwencja zatem obiecuje gwarancję na życie, a trzymanie się utartych schematów to - i dla bohatera, i dla utożsamiającego się z nim widza - licencja na przeżywanie (wykupione ubezpieczenie doczekało się obiegowej nazwy: happy end). W Funny Games Haneke pokazuje, że to ubezpieczenie jest podwójne: o tym, że wszystko jest w porządku, utwierdzają widza schematy gatunkowe, ale także sfera muzyczna - reprezentowana przez sztandarowe utwory muzyki klasycznej, a więc głos wysoce autorytatywny.

Można powiedzieć, że muzyka słuchana przez bohaterów rozszerza fałszywą gwarancję bezpieczeństwa i niezawodności: nie chodzi jedynie o fałsz filmowych konwencji, bez których szybko stajemy się bezradni (o emocjonalnej i intelektualnej bezradności widza po zanegowaniu tych konwencji sugestywnie świadczą opinie na temat Funny Games zamieszczane na portalach filmowych ${ }^{81}$ ), chodzi o fałsz całej współczesnej kultury - z jej iluzją powszechnego bezpieczeństwa i coraz wyższą ceną, jaką za to bezpieczeń-

${ }^{80}$ Zob. P. Sloterdijk, Kryształowy pałac, O filozoficzna teorię globalizacji, tłum. B. Cymbrowski, Warszawa 2011.

${ }^{81}$ „Jestem wrażliwą osobą i jakoś nie skłonił mnie do refleksji, film jest płaski, pozbawiony emocji, a dlaczego, bo jest tak głupi, że aż boli. Dwójka psycholi bawi się $\mathrm{z}$ widzem i robi z nich durnia, śmiejąc mu się w twarz. Moje przemyślenia? Gniot, na którym ktoś chciał naszukać kasy i pewnie naszukał, najwięcej na małolatach i pseudointelektualistach, chciał zrobić dramat, a wyszła mu parodia thrillera". 
stwo trzeba płacić. Argumentów uzasadniających konieczność transakcji i podwyższenia stawki opłat dostarczają na bieżąco media, pełne doniesień o wszelkich możliwych zamachach, kataklizmach i kryzysach ${ }^{82}$.

Do konstruowania podwójnego ubezpieczenia, dublowania poczucia asekuracji autorytarnością tonu, szczególnie predysponowana jest muzyka barokowa czy postromantyczna. Bywa ona oparta na stosunkowo łatwych do wychwycenia schematach (harmonicznych, melodycznych) i czytelnych napięciach adresowanych do konkretnych emocji (patos, melancholia, radość, rozpacz), stąd jej lawinowo rosnąca popularność w ostatnich dziesięcioleciach, w epoce dominacji kultury lekkostrawnej i mającej służyć rozrywce. Znamienne, że bohaterowie Funny Games nie słuchają w samochodzie klasycznej muzyki współczesnej - wymagającej od widza więcej intelektualnego zaangażowania, mocniej napiętej uwagi, ale też zawierającej elementy oporu wobec sytej, konsumenckiej rzeczywistości - tylko właśnie utworów sprzed dwóch stuleci, zalecających się do słuchacza swym estetycznym urokiem, a co ważniejsze, łudzących łatwą przyswajalnością oraz kulturową swojskością ${ }^{83}$.

W tym kontekście możemy spróbować inaczej spojrzeć nie tylko na ofiary (których wina okazuje się „odziedziczona” po stuleciach zachodniej cywilizacji, grzech natomiast jest niejako „pierworodny”, niezmyty żadnym chrztem ani autentycznym rytuałem przejścia), lecz także na parę

Opinia internauty zamieszczona na: www.twojefilmy.pl/funny-games/ [dostęp: 30.05.16].

82 „Przy okazji premiery Funny Games reżyser przestrzegał przed fałszywym obrazem świata, jaki prezentują media, obwiniał je za kreowanie, a nie opisywanie rzeczywistości, tworzenie uproszczeń, generalizowanie i relatywizowanie. Szczególnie niebezpieczne wydawało mu się to przy okazji kwestii związanych z przemocą, która dzięki telewizji stała się tematem o walorach rozrywkowych". K. Wolanin, Zrozumieć Michaela Haneke, http://liberte.pl/zrozumiec-michaela -haneke/ [dostęp: 30.05.16].

83 „Na początku filmu klasyczna muzyka w wykonaniu Gigliego i Tebaldiego zostaje użyta do zasygnalizowania stanu świadomości trójki protagonistów, wprowadzając w nastrój filmu. Muzyka, rozwijająca się równolegle z pięknem krajobrazu w ujęciu otwierającym film, usypia czujność widzów, dając im fałszywe poczucia bezpieczeństwa”. Sounds In Haneke's „Funny Games”, www.academia. edu/14328396/Sound_in_Hanekes_Funny_Games_U.S [dostęp: 30.05.16]. 
morderców. I wtedy okaże się, że wcale nie są oni wysłannikami z zewnątrz, pozbawionymi cech ludzkich funkcjonariuszami terroru, którego źródeł nie mamy szans poznać. Wbrew regułom thrillera czy horroru, widz nie może poczuć się niewinną ofiarą przemocy, emocjonalnie utożsamić się z rodziną w śmiertelnym niebezpieczeństwie, ponieważ ma też cechy upodabniające go do pary zbrodniarzy. Aseptyczną schludność Petera i Paula można odbierać jako odbite w krzywym zwierciadle zamiłowanie do ładu i porządku (oto perfekcyjni panowie domu dwaj), dyktowane nam, rzecz jasna, przez media i wzorce kulturowe.

Haneke twierdzi, że jako widzowie, użytkownicy Internetu, pensjonariusze portali społecznościowych, nie grzeszymy jedynie biernością i zaniedbaniem, ale przede wszystkim zgodą na fałsz i strukturalne złudzenie, które przynosi świat elektronicznych mediów. Nieuchronne ujawnienie fałszu i pęknięcie złudzenia rodzi agresję - tym powszechniejszą, im media są bardziej masowe, utrzymującą się tym bardziej permanentnie (jako stały stan cichej irytacji czy frustracji), im bardziej media stają się częścią naszej codzienności. W wywiadzie dla kinowego magazynu „Kinoeye” reżyser powiedział o tym - jak na niego - wyjątkowo wprost:

Nowe technologie, którymi posługują się zarówno media, jak i świat polityki, wywołują wielkie zniszczenia swoim niepohamowanym wzrostem i szybkością rozprzestrzeniania się. Media przyczyniają się do tworzenia dość niepokojącej iluzji, że w danej chwili jesteśmy informowani o wszystkim, co się właśnie dzieje, każda informacja ma status nagłej. Żyjemy w otoczeniu pozwalającym nam myśleć, że dowiadujemy się o wszystkim szybciej, kiedy tak naprawdę nie wiemy nic. To rodzi straszne konflikty wewnętrzne, one powodują złość, która znowu przemienia się $\mathrm{w}$ agresję, a ta prowadzi do aktów przemocy ${ }^{84}$.

Jeżeli do słów reżysera dodamy, zapowiadającą pojawienie się dwójki morderców, gwałtowną muzykę Johna Zorna, która drążąc mroki ludzkiego „ja”, rozrywa tkankę muzycznej iluzji dobrostanu i harmonii zmysłów (w ten sposób podświadomość raptownie przebija się przez świadomość), to wtedy może się okazać, że Peter i Paul są wysłannikami naszego skonfliktowanego

${ }^{84}$ Cyt. za: J. Topolski, 27 fragmentów..., op. cit. 
wnętrza (które przybywa, by zrobić porządek z bałaganem na zewnątrz), emisariuszami frustracji i złości ogarniającej całe społeczeństwa. Czyli że reprezentują właśnie nas, widzów, a nie jakąś zewnętrzną rzeczywistość terroru i horroru ${ }^{85}$. Cień rzucany przez Petera i Paula - tak jak cień rzucany na Mozarta i Haendla przez gitarowo-saksofonowy jazgot Johna Zorna - jest cieniem padającym od wewnątrz, a nie z zewnątrz.

Haneke niby pozwala publiczności solidaryzować się z ofiarami (by koniec końców zakpić sobie $\mathrm{z}$ widza i jego nadziei), ale jeżeli konsekwentnie pójść za tym, czego reżyser oczekuje (czyli przełamania stereotypowego oglądu - i sztuki filmowej, i rzeczywistości), a także za tym, co sugeruje wprowadzająca nas w filmowe zdarzenia muzyka (że jako użytkownicy kultury przychodzimy na świat z jej grzechem pierworodnym i że nie jest to grzech bezkarny), może się to skończyć paradoksalnym zrozumieniem dla poczynań dwójki morderców. Poczynania te bowiem okazują się nie aż tak psychopatycznie irracjonalne, jak mogłoby się zdawać. Cały film wypada wtedy obejrzeć raz jeszcze.

Wróćmy zatem do pierwszej sceny Funny Games i zauważmy, że kamera towarzyszy samochodowi, który jedzie przez pełną naturalnego piękna okolicę, obserwując go wysoko z góry, podobnie jak w słynnym początkowym ujęciu ze Lśnienia Stanleya Kubricka. Podobieństwo wygląda na nieprzypadkowe, aczkolwiek film Kubricka - także rozsadzający ramy gatunku, do którego teoretycznie należy - daje szersze możliwości interpretacyjne zarówno na poziomie konkretnych faktów (w jego symbolice doszukiwano się aluzji do zagłady Indian północnoamerykańskich, a także sugestii kwestionujących autentyczność pierwszego lądowania astronautów na Księżycu ${ }^{86}$ ), jak i na płaszczyźnie ogólniejszej, która obejmuje sięgające w Jungowską zbiorową podświadomość fundamenty całej współczesnej kultury $^{87}$. Jest to związane z odmiennym - niż w Funny Games - użyciem przez

85 „Publiczność staje się wspólnikiem zabójców”. Michael Haneke w rozmowie z Sergem Toubianą, op. cit.

${ }^{86}$ Rodney Ascher nakręcił dokument Pokój 237, film w całości poświęcony tropom interpretacyjnym i narracyjnym w Lśnieniu Kubricka i stanowiący nader rzetelny katalog tych rozlicznych wątków.

${ }^{87}$ „King musiał zrozumieć, że jego opowieść psychosocjologiczną [...] Kubrick zmienił w antropologiczną, przedstawiając przyczyny i objawy rozpadu 
Kubricka muzyki, która staje się nie tylko wyrafinowanym komentatorem ekranowych wydarzeń, ale także aktywnym czynnikiem sprawczym, równie ważnym dla zsumowanego efektu artystycznego (czyli gotowego filmu), jak aktorzy czy scenariusz ${ }^{88}$. Na czysto technicznym poziomie synchronizacji, Funny Games - ze swoim wręcz prowokującym oddzieleniem symbolicznie „muzycznej” czołówki od „pozamuzycznej” właściwej akcji - jest oczywiście zamierzonym przeciwieństwem metody Kubricka (znanego ze swoich iście zegarmistrzowskich operacji montażowych oraz emancypacji muzyki w filmie aż do osiągnięcia przez nią znaczenia równego grze aktorów $\left.{ }^{89}\right)$. Jednak ostateczny efekt pozwala zobaczyć w pomyśle z czołówką Funny Games raczej błyskotliwy filmowy greps niż pomysł artystyczny, który porusza naprawdę głęboko. Gdyby nie kontrast między cokolwiek tarantinowskimi manierami morderców (i takimiż dialogami między nimi) a grającymi $\mathrm{w}$ zupełnie inny, momentami skrajnie naturalistyczny sposób aktorami wcielającymi się członków terroryzowanej rodziny, można by zadać pytanie: czy Hanekemu nie jest aby w tym filmie bliżej do Quentina Tarantino niż choćby do Sama Peckinpaha?

Warto w tym kontekście przyjrzeć się bliżej powołanym do filmowego życia mordercom o chłopięcym wdzięku i nienagannych manierach. Z całą pewnością (co ucieszyłoby Michaela Hanekego) nie sprawiają oni wrażenia urodzonych morderców - są reżyserskim konstruktem (w dodatku nieco

uporządkowanego bytu i regresu człowieczeństwa”. Lśnienie, [w:] A. Garbicz, Kino, wehikuł magiczny. Podróż piąta 1974-1981, Kraków 2009, s. 496.

${ }_{88}$ J. Topolski, Kino/Muzyka. Zbliżenia. Gambit Kubricka, „Ruch Muzyczny” 2009, nr 8; idem, Muzyka w filmach Stanleya Kubricka, http://stopklatka.pl/news/ muzyka-w-filmach-stanleya-kubricka [dostęp: 30.05.16].

${ }^{89}$ „Obsesja synchronizacji - [...] na przykładzie z Lśnienia - ma na celu maksymalne przybliżenie utworu muzycznego do postaci. Jeśli Kubrick posuwał się do odtwarzania muzyki na planie zdjęciowym, to znaczy, że dążył do uzyskania efektu pełnej tożsamości pomiędzy grą aktorską a ścieżką muzyczną. Traktował tę drugą jako niezbędne dopełnienie pierwszej. Wydaje mi się, że linia przebiegająca pomiędzy kreacją aktorską a muzyką jest jedną z najważniejszych osi, wokół których Kubrick buduje swoje filmy". A. Łazarkiewicz, Muzyka z podświadomości. Praktyczne i teoretyczne aspekty wykorzystania muzyki w filmie na podstawie analizy „Lśnienia” Stanleya Kubricka, „Glissando” 2007, nr 10/11. 
„operowym” w swym sztucznym przerysowaniu). Pomysł uczynienia z nich nosicieli symbolicznego zła (zagnieżdżonego gdzieś w utajonym sercu kultury i - jak przystało na jej przymioty: „masowa”, „globalna”, „elektroniczna” - błyskawicznie roznoszonego przez cyfrowy krwiobieg ${ }^{90}$ ), jest nośny jedynie na poziomie służebnym wobec ideowego przesłania filmu. Poza nim Peter i Paul okazują się postaciami marionetkowymi, animowanymi sztucznie i w ściśle pragmatycznym celu. Używane przez parę morderców białe, aseptyczne rękawiczki okazują się rękawiczkami na dłoniach samego reżysera.

Za porównanie może posłużyć podobna para - tyle że tym razem morderczyń, a nie morderców - uśmiercająca stateczną, mieszczańską rodzinę w filmie Clauda Chabrola Ceremonia. Lista podobieństw między filmami Hanekego i Chabrola jest zresztą znacznie dłuższa: u francuskiego reżysera zamordowana rodzina jest co najmniej tak samo dobrze sytuowana $\mathrm{i}$ - to bardzo znamienne pokrewieństwo - co najmniej tak samo rozmiłowana w muzycznej klasyce, która towarzyszy kulminacyjnej scenie filmu. W Ceremonii jednak bohaterki są jak najbardziej realne: mają wyraziste, wiarygodnie sportretowane osobowości, a zarówno ich początkowa, dziecinna wręcz niefrasobliwość, jak i stopniowo narastająca frustracja są bystro podpatrzone u rzeczywistych ludzi, choć ukazane na ekranie nader powściągliwie i z wiarą w inteligencję widza, szczególnie tę emocjonalną.

Oczywiście, Haneke celowo jest wyraziście alegoryczny (tak jak alegoryczna jest scena ze słuchaniem muzyki na początku filmu: Haendel, Mascagni - dobro i bezpieczeństwo, Zorn - zło i groza), natomiast Chabrol, w zgodzie z uprawianym od lat stylem, wybiera dyskretną metonimię. Bohaterki Ceremonii, Sophie i Jeanne, pochodzą z niższej klasy społecznej. Ich morderczy uczynek na tle anielsko harmonijnej, ale i złowrogiej muzyki Mozarta (rodzina słucha opery Don Giovanni), odniesiony do całych grup społecznych ukazuje destrukcyjną siłę „buntu mas” (czyli przewidzianego przez José Ortegę y Gasseta stanu „triumfu hiperdemokracji”"1). Niezależnie

${ }_{90}$ Z przebiegu wypadków łatwo orientujemy się, że trwająca półtorej ekranowej godziny egzekucja trzyosobowej rodziny jest tylko epizodem, bo chłopcy mordują jedną rodzinę za drugą, a czas wakacji i sceneria pustkowia nad jeziorem pozwalają widzieć w nich prawdziwych morderców-pracoholików.

91 „Masy działają bezpośrednio, nie zważając na normy prawne, za pomocą nacisku fizycznego i materialnego, narzucając wszystkim swoje aspiracje 
od metaprzesłania obu filmów, na tle precyzyjnie szkicowanej osobowości bohaterów oraz bystrego postrzegania przez Chabrola niuansów i półcieni w społecznych relacjach (Jakub Majmurek pisał o „subtelnych narzędziach krytyki społecznej" u francuskiego reżysera ${ }^{92}$ ), pomysły Hanekego z Funny Games zakrawają na reżyserskie efekciarstwo.

Z drugiej strony, trzeba pamiętać, że pełny tytuł opery Mozarta brzmi Il dissoluto punito ossia il Don Giovanni, co po polsku oznacza: „Rozpustnik ukarany, czyli Don Giovanni”, więc i Chabrolowi - który wymierza wywyższającym się burżujom karę przez rozstrzelanie - można by tu zarzucić zbyt grubo ciosaną metaforykę. Natomiast jeżeli chodzi o Hanekego, to ten już niedługo (Funny Games i Pianistkę dzielą cztery lata) pokaże, że potrafi udzielić muzyce w filmie znacznie szerszych, narracyjnych kompetencji. Zmiana ta nie oznaczała odcięcia się od przeszłości, ponieważ reżyser wcale nie porzucił błyskotliwych na granicy brawury pomysłów w rodzaju tego z Funny Games. W ostatecznym rozrachunku jednak potrafił nadać muzyce - lub pozwolić, by ona sama go sobie nadała - dużo istotniejszy wymiar.

\section{PIANISTKA, CZYLI MUZYKA JAKO WOLA I PRZEDSTAWIENIE}

Zupełnie inaczej niż w Funny Games, początek Pianistki oglądamy w całkowitej ciszy i ciemności, a pierwsze sceny (mocno wyodrębniony prolog

i upodobania”. J. Ortega y Gasset, Bunt mas, tłum. P. Niklewicz i H. Woźniakowski, Warszawa 2008, s. 12.

92 „Dom zamożnej, pełnej pretensji, prowincjonalnej, mieszczańskiej rodziny obserwujemy tu z punktu widzenia niepiśmiennej służącej (Sandrine Bonnaire). Chabrol doskonale pokazuje tu, że mieszczańska kultura opiera się na dystynkcji i wykluczeniu; mieszczańskie wartości kulturalne są wartościami tylko o tyle, o ile zostaną przeciwstawione komuś, kto jest wykluczony z udziału w nich (służba, ale także proletariat, czy nielegalny imigrant). Służąca zaprzyjaźnia się z odrzuconą przez pana domu kochanką, prowadzącą dość hipisowski styl życia pracownicą poczty. Na końcu obie kobiety biorą rewanż na świecie, który ich odrzucił, i przy pomocy drogiego sprzętu myśliwskiego mordują rodzinę pracodawców, gdy ta ogląda w telewizji inscenizację Don Giovanniego Mozarta”. J. Majmurek, Claude Chabrol (1930-2010) cyniczny (a)moralista, „Dwutygodnik” 2010, nr 10(40), www.dwutygodnik.com/artykul/1486-claude-chabrol-1930-2010-cyniczny-amoralista.html [dostęp: 30.05.16]. 
ukazujący fundamentalny problem filmu - patologiczną relację bohaterki z matką) obywają się bez muzyki, co jest tym bardziej zaskakujące w kontekście tytułu. Ten zaś pojawia się dopiero po siedmioipółminutowym wstępie. I dopiero wtedy - niejako poprzedzona dramatyczną, emocjonalną i fizyczną szarpaniną między bohaterkami - wybucha na ekranie, romantycznymi frazami Fantazji f-moll Fryderyka Chopina, muzyka fortepianowa. Mogłoby to sugerować, że reżyser zrobił dokładnie na odwrót, niż uczynił wcześniej: muzyka nie będzie tym razem antycypowała dalszego rozwoju akcji, lecz prowadziła kronikę wydarzeń (w dużej mierze miłosnych). Jednak sposób prezentacji kolejnych utworów świadczy o tym, że ich miejsce w dramaturgicznej tkance filmu nie jest określone na stałe. Kompozycje raz będą komentarzem, innym razem głębszą analizą. Raz - wprowadzą prosty kontrast, innym razem - złożony kontrapunkt.

Podobnie stało się z budowaniem filmowych postaci. Wstępna scena zwięźle i dobitnie zapoznająca widza $\mathrm{z}$ patologicznymi relacjami między bohaterką (graną przez Isabelle Hupert) a jej matką (w tej roli Anne Girardot) oraz ukazująca rodzinny dom jako piekło emocjonalnego terroru (Haneke, jak wiadomo skądinąd, dość zdecydowanie postrzega rodzinę jako źródło cierpien ${ }^{93}$ ) - wydaje się komentowana muzycznie dopiero później. Komentowana - podkreślmy - za pomocą dzieł kompozytorów po rodzinnych przejściach. Owi kompozytorzy to: Franz Schubert, którego ukochana, decyzją rodziny, wyszła za mąż za piekarza; Robert Schumann, który jako piętnastolatek doświadczył samobójczej śmierci siostry, a później został przez matkę zmuszony, wbrew aspiracjom muzycznym, do podjęcia studiów prawniczych; Ludwig van Beethoven, którego liczne choroby i cierpienia mogła, według badaczy, spowodować tak zwana kiła wrodzona, czyli otrzymana w spadku genetycznym.

Celowo przytaczam fakty z biografii kompozytorów romantycznych, których muzyka buduje akcję filmu równolegle ze zdarzeniami z życia jego bohaterów, ponieważ jednym z zasadniczych wątków jest właśnie hipotetycznie sugerowana współzależność, symboliczna więź pomiędzy skomplikowaną psychiką artystki (tytułowej pianistki) a żyjącymi dwa stulecia

93 „Chciałbym przede wszystkim [...] stwierdzić, że rodzina to wylęgarnia konfliktów, [...] codzienna wojna w rodzinie jest swego rodzaju mordowaniem się, a to rodziców i dzieci, a to żon i mężów”. The World That Is Known, op. cit. 
wcześniej kompozytorami muzyki, którą owa artystka wykonuje ${ }^{94}$. Taka perspektywa pozwala zrezygnować $\mathrm{z}$ traktowania relacji „filmowe wydarzenia - komentarz muzyczny" z perspektywy czasowego następstwa czy związku przyczynowo-skutkowego, a zacząć widzieć między akcją filmu i muzyką podobny związek, jaki istnieje między semantyką i syntaktyką. Muzyka z Pianistki może być zatem „gramatyką", która staje wobec „słownika" zdarzeń czy emocji bohaterów. I dopiero razem wzięte, tworzą giętki język tego niezwykłego filmu, w którym rozgrywa się niby współczesny, a w istocie stary jak ludzkość dramat samotności, dominacji, niespełnienia, którego schematy zostały wpisane w nuty muzyki romantycznej.

Po takim wstępnym rozpoznaniu przyjrzyjmy się bliżej, w jaki sposób muzyka z Pianistki towarzyszy rozwojowi akcji filmu albo wchodzi w relacje z poszczególnymi wydarzeniami. Jako pierwszy utwór - pojawiający się pod palcami grającego pianisty ćwiczącego w konserwatorium, gdzie profesorką fortepianu jest Erika Kohut, tytułowa bohaterka filmu - słyszymy Fantazje f-moll Fryderyka Chopina, czyli utwór, którego powstanie w październiku 1841 roku zostało spuentowane listem kompozytora do Juliana Fontany ze słynnym fragmentem: „Dziś skończyłem Fantazję - i niebo piękne, smutno mi na sercu - ale to nic nie szkodzi. Żeby inaczej było, może by moja egzystencja nikomu na nic się nie przydała. Schowajmy się na po śmierci" I choć Michael Haneke wybrał fragment tego utworu raczej ze względu na jego typowy dla epoki romantyzmu charakter, a nie biograficzne czy muzykologiczne niuanse, to w kontekście rozwoju akcji Pianistki (o kryzysowej sytuacji w domu rodzinnym już wiemy, za chwilę dowiemy się o mrocznych kulisach pracy w konserwatorium oraz perwersyjnym życiu erotycznym bohaterki) okazuje się on znamienny. W ten sposób użyta w filmie muzyka przemawia niezależnie od zamierzeń reżysera.

Istotny dla filmu okazuje się bowiem i chopinowski „smutek na sercu” (Erika Kohut też okazuje się pogrążona w chronicznej depresji, niezbyt obecna ciałem: nawet podczas kontaktu seksualnego jej ręce wiszą bezwładnie jak u kukły), i melancholijne zdanie: „żeby inaczej było, może by

94 „Trudno określić, na ile istnieje korelacja między neurozą Eriki Kohut a tym, co można by nazwać "psychogramem« wielkiego kompozytora, jakim był Schubert". Ibidem.

${ }^{95} \mathrm{http}: / /$ pl.chopin.nifc.pl/chopin/genre/detail/id/21 [dostęp: 30.05.16]. 


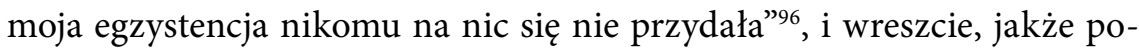
etycka fraza: „schowajmy się na po śmierci”. Jak dowiemy się już wkrótce, Erika - ukrywając przed matką, kolegami z konserwatorium oraz kręgami wiedeńskich melomanów nadzwyczaj istotną część swojej osobowości (czyli upodobanie do praktyk sadomasochistycznych, drastyczny voyeuryzm, znajdowanie erotycznej rozkoszy w upokarzających formach kontaktu) $\mathrm{w}$ istocie chowa to, co dla niej najważniejsze (ukryte pod warstwą perwersji zwyczajne pragnienie miłości). Pianistka ukrywa przed otoczeniem swoją prawdziwą osobowość, prawdziwe życie. A w życiu, które wiedzie oficjalnie, w zgodzie z obowiązującymi normami społecznymi, na wszystko robi się dramatycznie za późno.

Jeżeli zajrzymy pod podszewkę Chopinowskiej Fantazji f-moll nie od strony biografii kompozytora, lecz formy utworu, także natrafimy na istotne dla wydarzeń z filmu Hanekego fakty (szczególnie w kontekście rozwichrzonej, wymykającej się normom budowy kompozycji ${ }^{97}$, której Fantazja zawdzięcza swoją witalną energię i organiczną siłę). Osobowość Eriki również zbudowana jest na sprzecznościach (wykonawczyni uduchowionej muzyki Jana Sebastiana Bacha okazuje się wielbicielką brutalnego seksu; autoryta-

${ }^{96}$ Jak sugerują bystro podpatrzone w Pianistce scenki rodzajowe z wiedeńskiego konserwatorium, warunkiem osiągnięcia muzycznej doskonałości jest mozolna, pełna cierpień i represji droga per aspera ad astra; źródłem pianistycznego talentu bohaterki także nie jest z całą pewnością radość życia. Sam reżyser stwierdza, że: „Wiedeń jest stolicą muzyki klasycznej i w związku z tym jest centrum wszelkiej nadzwyczajności. Muzyka jest bardzo piękna, lecz tak jak towarzyszące jej okoliczności, może stać się narzędziem represji”. The World That Is Known, op. cit.

97 „Interpretatorzy muzykologiczni utworu, którym nie była znana ta właśnie zasada gatunku, nie umieli sobie długo poradzić z kształtem Fantazji f-moll. Niecks znalazł w Fantazji »zniewalającą dziwność i »chimeryczność" formy. Leichtentritt odczytał formę utworu jako »niejasną", cierpiącą na »brak logiki i ciągłości w budowie«. Dla jednych była jedynie »serią oszołamiających obrazów « prezentowanych "w wielkim uniesieniu«, "przesuwających się przed wyobraźnią słuchacza z szaloną szybkością«. Dla innych przekształconą, swoiście zdeformowaną formą tzw. sonatowego allegra, ronda, lub wynikiem skrzyżowania obu tych form”. M. Tomaszewski, Fryderyka Chopina Dzieła Wszystkie, audycja w Programie II Polskiego Radia, [cyt. za:] http://pl.chopin.nifc.pl/chopin/composition/detail/id/112 [dostęp: 30.05.16]. 
tywna wykładowczyni konserwatorium po powrocie do domu zmienia się w córeczkę ukrywającą przed surową matką występki i przewinienia), zaś na pozór wykluczające się cechy jej charakteru sięgają przeciwnych biegunów nie tylko zawodowej, ale i ludzkiej moralności (imponujące kompetencje profesorki gry na fortepianie sąsiadują ze skłonnością do brutalnej złośliwości, cynicznego szyderstwa, a nawet aktów okaleczającej przemocy). Dzieje się tak wskutek wewnętrznych konfliktów, które targają Eriką od tak dawna, że w zasadzie stały się nieusuwalną częścią jej psychiki i cielesności. Co nie zmienia faktu, że ta neurotyczna czterdziestoparolatka, uzależniona od ostrej pornografii i zatrzymana przez matczyny terror na emocjonalnym poziomie krnąbrnej gimnazjalistki, pozostaje - w dużej mierze dzięki kreacji Isabelle Huppert - fascynującą kobietą. Huppert wniknęła w swoją bohaterkę na tyle głęboko, żeby w wywiadzie dać jej sugestywnie zwięzłą charakterystykę: „Erika to ktoś, kto neguje swe ciało, ale jej ciało budzi się wbrew jej woli. To, w pewnym sensie, kobieta, która ucieka i przecieka. I przecieka wszystkim: krwią, moczem, wymiotami. Jest to jednocześnie ciało zamknięte w gorsecie i ciało otwarte na oścież. Ta dwoistość intrygu$\mathrm{je}^{\text {"98. }}$. Na podobnej dialektyce formy (między innymi sonatowej) i jej negacji Chopin oparł swoją Fantazję f-moll.

Celowo poświęcam tak dużo uwagi utworowi, który pojawia się w Pianistce zaledwie na kilkanaście sekund i w zasadzie nie ma znaczenia dla powierzchniowej warstwy fabuły filmu. Po pierwsze, chcę zwrócić uwagę, jak poważne implikacje - niezależne od intencji reżysera - pociąga za sobą wykorzystanie romantycznej „muzyki po przejściach”, po drugie zaś, chcę pokazać, jak mogą zmieniać się niuanse w odbiorze filmu Hanekego w zależności od kraju, gdzie jest oglądany: polski widz będzie z natury rzeczy mocniej „obciążony” muzyką Chopina (z całym jej muzyczno-biograficzno-kulturowym bogactwem ${ }^{99}$ ), natomiast widz austriacki będzie mocniej

98 Cyt. za: G. Arata, op. cit.

99 „Chopin nie operował w Fantazji f-moll cytatem. Ani dosłownym - jak niegdyś w Fantazji A-dur na tematy polskie, ani przybliżonym, jak to uczynił w Scherzu h-moll z kolędą Lulajże Jezuniu lub w Mazurku e-moll, "palmejskim", $\mathrm{z}$ pieśnią Tam na błoniu błyszczy kwiecie. Litwinka zaistniała w Fantazji f-moll poprzez działanie nie cytatem, a aluzją. Jest w utworze obecna, lecz na sposób dyskretny. Trzeba ją w nim wysłyszeć”. M. Tomaszewski, op. cit. 
„obciążony” muzyką kompozytorów wiedeńskich - Schuberta i Beethovena (z całą aurą ewokowaną przez to miasto ${ }^{100}$ ). To drugie "genetyczne obciążenie" dotyczy także samego Hanekego, więc tym istotniejsze wydają się wszystkie konteksty, które muzyka z Pianistki ujawnia nie tyle zgodnie czy wbrew, ile po prostu poza zasadą reżyserskiej wszechmocności.

Skoro pokazałem schemat, według jakiego muzyka współdziała z filmem (czyniąc z niego „dzieło otwarte”, nieustannie gotowe na reinterpretacje), kolejne fragmenty, w których istotną rolę pełni muzyka, omówię już w bardziej bezpośrednim związku z akcją filmu. Pierwszą sceną z muzyką towarzyszącą bohaterom przez dłuższy czas jest scena domowego koncertu, na którym Erika Kohut poznaje swojego przyszłego ucznia, Waltera Klemmera (całkiem sympatyczny charakter postaci Waltera to element, w którym film najbardziej różni się od powieści Elfriede Jelinek ${ }^{101}$ ). Erika w duecie $\mathrm{z}$ innym pianistą odgrywa przed gośćmi Fugę z Koncertu C-dur na dwa klawesyny Jana Sebastiana Bacha. Ten pełen entuzjastycznej energii utwór dobrze oddaje nastrój koncertu (aura snobizmu nie wyklucza tu wzajemnej serdeczności i autentycznej miłości do muzyki), a także staje się lustrem odbijającym pierwszą rozmowę Eriki z Walterem.

Szarmanckie powitanie („Pozwolę sobie ucałować dłoń, która gra Bacha w takim stylu") znajduje kontynuację w rozmowie, w której muzyczna erudycja obydwojga tworzy między bohaterami nić porozumienia (Walter mówi o muzyce „nad wyraz dojrzale”, a fakt, że jest studentem politechniki, nie pozbawia go szacunku dla „tradycji prywatnych recitali”; Erika natomiast potrafi podjąć ironiczną konwencję, daleką od sztywnych kanonów filharmonii), ale także od razu sugeruje istotne różnice. Walter zdradza

100 „Owszem, można uznać, że muzyka funkcjonuje w ten sposób, lecz dodatkowo trzeba mieć świadomość, że w filmie oglądamy specyficznie austriackie realia". The World That Is Known, op. cit.

101 „Christopher Sharrett: Walter Klemmer wydaje się bohaterem filmu, aż nagle staje się potworem. Michael Haneke: Niech pan to powie Elfriede Jelinek [śmiech]. No, ale żarty na bok. Jego charakter jest ukazany w książce dużo bardziej negatywnie niż w filmie. Książka jest napisana w nader cynicznej manierze, opisuje przemianę infantylnego kretyna w faszystowskiego dupka. Mój film próbuje uczynić go postacią trochę ciekawszą i atrakcyjniejszą". The World That Is Known, op. cit. 
skłonność do prowokacyjnej dezynwoltury i łamania konwencji („Dziś tylko akademicy stepują w rytm słoni Brucknera”), Erika zaś preferuje mocniejsze stąpanie po ziemi oraz bardziej skrupulatną uniwersytecką wiedzę („Czytał pan esej Adorna o Fantazji C-dur Schumanna?”), choć przy okazji sugeruje, jakie mogą być ciemne źródła jej patologicznej sytuacji rodzinnej (Erika: „To Schumann tuż przed utratą zmysłów. Wie, że traci głowę. Ma świadomość bliskiej katastrofy, całkowitego zatracenia”. Walter: „Mówi pani o tym jak o własnym życiu”. Erika: „Uwielbiam Schuberta i Schumanna. Mój ojciec zwariował i zmarł w szpitalu w Steinhof. Dlatego łatwo mi mówić o zmierzchu duszy").

Choć podteksty tych wyznań wydają się niepokojące, to cała scena utrzymana jest w serdecznej atmosferze - dokładnie takiej, jak odegrana Fuga z Koncertu Bacha. Tę pogodną atmosferę, skontrastowaną z potencjalnie mrocznymi treściami, można odnieść do podstawowych różnic między Bachem a Schubertem czy Schumannem - zarówno na poziomie muzyki, jak i biografii tych kompozytorów. Życie Jana Sebastiana Bacha, stosunkowo długie i dostatnie, było życiem kompozytora, owszem, rzuconego przez los na prowincję, ale spełnionego męża i ojca, człowieka o mocnym charakterze, stabilnej psychice, którego muzyczny geniusz nie kazał płacić za siebie tak horrendalnej ceny, jak w przypadku kompozytorów muzycznego romantyzmu. Skrajnie odmienne było życie Franza Schuberta czy Roberta Schumanna. Schubert cierpiał biedę spowodowaną ogólną niezaradnością życiową, musiał zrezygnować ze związku z ukochaną kobietą (rodzina znalazła jej solidniejszą małżeńską partię), jego jedyny publiczny koncert został powszechnie zignorowany, bo w Wiedniu występował akurat słynny skrzypek Nicolo Paganini, zaś na domiar nieszczęścia, podczas krótkiej wizyty z domu publicznym zaraził się kiłą, która - wespół z wyniszczającym leczeniem rtęcią - spowodowała jego śmierć $\mathrm{w}$ wieku zaledwie 31 lat. Schumann żył, jak na romantyka, dość długo - 46 lat, ale przez większą część życia zmagał się z narastającą chorobą psychiczną (słyszał głosy w głowie, aż do schizofrenicznego rozdwojenia jaźni), która miała traumatyczne źródła w dzieciństwie (samobójcza śmierć starszej siostry, nagły zgon ojca) i skończyła się drastyczną próbą samobójczą, po której trafił dożywotnio do szpitala psychiatrycznego. Dodatkowo na drodze do życiowego spełnienia stanęła Schumannowi matka, która wbrew artystycznym aspiracjom syna 
zmusiła go do studiów prawniczych - leczył więc frustrację alkoholem i przygodnym seksem.

Z premedytacją przytaczam te biogramy w wersji uproszczonej, aby pokazać „mityczną” obecność kompozytorów w zachodniej tradycji i kulturze. Ów „mit” znajduje wszakże sugestywne oparcie w muzyce (u Bacha w dużej części jasnej i klarownej; u Schuberta czy Schumanna - skłonnej do ciemnego liryzmu i neurotycznego rozedrgania), a w filmie Hanekego ogarnia bohaterów (zanurzonych po uszy w środowisku muzycznym Wiednia) swoim kulturowym cieniem. Jak się wkrótce okaże, życiowe dramaty Eriki oscylują wokół problemów rodzinnych i uczuciowo-seksualnych, podobnie jak życiowe dramaty kompozy torów otoczonych „romantycznym” nimbem. Na razie Walter o tym nie wie, ale jest wyraźnie poruszony osobowością Eriki, a kiedy okazuje się, że on także (zaskakująco uzdolniony muzycznie jak na studenta kierunków ścisłych) ma swój występ podczas koncertu, podejmuje znaczącą decyzję - zamiast zacząć grać zaplanowaną miniaturę fortepianową Schönberga, oświadcza: „Zagram mój ulubiony utwór Schuberta - Scherzo z Sonaty A-dur".

Widzimy już, na jak różne sposoby muzyka towarzyszy bohaterom filmu zarówno bezpośrednio (uprzedzając lub komentując ich poszczególne kroki), jak i z kulturowego dystansu, czyniąc aluzje skierowane bezpośrednio do widza (który najpierw pomyśli o „mitycznym” Wiedniu - mieście Beethovena i Freuda, ale także Wolfganga Přiklopila - a potem dokona już własnych porównań i syntez ${ }^{102}$ ). Ta zmienność muzycznej perspektywy narracyjnej (szczególnie w pierwszej połowie filmu, bo w drugiej Haneke więcej inicjatywy oddaje kamerze) oraz swoboda w przechodzeniu na rozmaite poziomy, z jakich odzywa się muzyka jako narrator (dotyczy to zarówno chronologii zdarzeń, jak i wiwisekcji osobowości), czynią z Pianistki dzieło pod względem muzycznej narracji zupełnie wyjątkowe.

Chyba najbardziej podobny efekt do tego z Funny Games - czyli radykalnego skrótu, a przy okazji uderzającego widza kontrastu - reżyser osiąga w scenie, kiedy liryczny temat Andante z Tria fortepianowego Es-dur

102 „W założeniu twórcy Pianistka jest prowokacyjnym oskarżeniem pod adresem wiedeńskiej burżuazji. Podejmuje jednak kwestie bardziej uniwersalne. Film kręcony w dzielnicach i mieszkaniach wiedeńskich elit mógłby równie dobrze dziać się w Warszawie lub Tokio". G. Arata, op. cit. 
Schuberta towarzyszy wizycie Eriki Kohut w sex shopie. Znamiennym prologiem do tej sceny jest telefon od matki, pełny surowych napomnień adresowanych w stronę córki. Po chwili widzimy, jak utwór Schuberta jest ćwiczony na próbie przez trójkę skupionych muzyków (na fortepianie gra bohaterka filmu), po czym subtelna linia melodyczna - bez cięcia montażowego w sferze audio, a jedynie po cięciu w sferze obrazu - pozostaje z bohaterką, kiedy ta wybiera filmy w pełnym mężczyzn wiedeńskim sex shopie, by obejrzeć je w kabinie wideo. Wyrafinowany liryzm skrzypiec, wiolonczeli i fortepianu zderza się najpierw z wyrazami twarzy mężczyzn obserwujących jedyną w sex shopie kobietę, a później z jękami i okrzykami aktorów pornograficznego filmu oglądanego przez Erikę - dopiero wtedy Andante cichnie, ustępując pod naporem kontrastujących z nim dźwięków.

Scena jest zmontowana nadzwyczaj płynnie - ze świetnym wyczuciem czasu i rytmu poszczególnych ujęć - dzięki czemu melodia Schuberta w przewrotny estetycznie sposób komentuje dwoistość osobowości Eriki ${ }^{103}$ (a także w ogóle dualizm człowieka, w którym natura i kultura raz toczą ze sobą walkę, a innym razem tworzą zgodną w sprzecznościach hybrydę, gdzie to, co wzniosłe i szlachetne, zrasta się z trywialnym i obscenicznym ${ }^{104}$ ). W tym momencie warto raz jeszcze zwrócić uwagę na podobieństwa i różnice między filmem Hanekego a książką Jelinek, ale tym razem w najbardziej interesującym nas kontekście - wykorzystania utworów muzycznych w narracji. U obydwojga artystów nastrój czy emocjonalna wymowa kompozycji współgrają nie tylko z treścią ich dzieł, ale także z formą: u Hanekego - ze sposobem montażu ujęć i scen, natomiast u Jelinek - z rytmem języka i tym, jak „wchodzi” on w głowę bohaterów. Książka ma narrację trzecioosobową,

${ }^{103}$ „Wyższe uczucia są u niej zapośredniczone w patologicznym związku z matką, w muzyce oraz w pornografii. Wysokie i niskie, wzniosłe i patologiczne - jest w niej nierozdzielnie splecione". T. Sobolewski, Haneke. Wściekły i podstępny, "Gazeta Wyborcza” z dnia 20.11.2009 r., dodatek „Duży Format”, http://wyborcza. pl/duzyformat/1,127291,7267426,Haneke__Wsciekly_i_podstepny.html [dostęp: 30.05.16].

104 „Przejście prosto z koncertu, wciąż na tle romantycznej muzyki, do sex-shopu sprawia, że widz, chcąc nie chcąc, musi przyjąć punkt widzenia Eriki, zobaczyć pornografię jako wirtualny rytuał miłosny. Próba prawdziwej miłości przyniesie Erice nieszczęście, ale również świadomość, kim naprawdę jest”. Ibidem. 
narrator okazuje się nader szyderczym pełnomocnikiem autorki, opisy zmagań bohaterów z losem i własnymi uczuciami są przedstawiane tonem bezlitosnej kpiny, ale między innymi dzięki obecności muzyki dostrzegamy także ich wrażliwość. Oto przykład takiej „napędzanej” muzyką Schuberta i Schumana mieszanki czułości i szyderstwa: „Teraz we dwójkę wędrują zwiewnie przez luźno usypany pył pośrednich tonów, światów i dziedzin, bo na tym zna się warstwa średnia. Mroczniejący niepostrzeżenie Schubert otwiera cały korowód, czy też, jak pisze Adorno, mrocznienie w Fantazji C-dur Schumanna. I płynie w dal, w nicość, ale bez przeradzania się w apoteozę świadomego gaśnięcia!"105.

Haneke ma dla bohaterki na pewno więcej czułości niż szyderstwa, o czym świadczy już decyzja obsadowa (obdarzona subtelną urodą Isabelle Hupert gra w filmie kobietę, która w książce jest określona jako „ten nieforemny zezwłok, ta nauczycielka gry na fortepianie, na której dokładnie znać profesję [...]. Ta chorobliwie powykręcana, trzymająca się ideału dziwaczna istota"106), ale dla niniejszej pracy istotniejsze jest podejście do muzyki, a trzeba zauważyć, że i Haneke, i Jelinek wykorzystują sposób obecności klasycznych kompozycji w kulturze i społeczne mity związane z kompozytorami. U Hanekego mamy subtelnie lirycznego Schuberta rozbrzmiewającego w sex shopie (i burzliwe reakcje kinowej publiczności na drastyczny realizm dalszej części tej sceny, kiedy Erika wącha chusteczki zużyte przez masturbujących się mężczyzn), natomiast u Jelinek pojawia się kontrast między powszechnym zdrowiem społecznym (którym wszak cieszą się zarówno wielbiciele literatury, jak i kinomani - tak samo skłonni do wystawiania moralnych cenzurek) a przypadłościami ciała i ducha artystów. Spójrzmy na przykład na ten fragment: „To dogasanie światełka życia Schuberta i Schumanna to przecież skrajne przeciwieństwo tego, co sądzą zdrowe masy, kiedy tradycję nazywają zdrową i tarzają się w niej z lubością. Zdrowie - diabła tam. Zdrowie to uwznioślenie tego, co jest. Pismaki zapełniające programy koncertów filharmonicznych, aż wierzyć się nie chce, czynią ze zdrowia główne kryterium znaczącej muzyki"107.

\footnotetext{
105 E. Jelinek, Pianistka, tłum. R. Turczyn, Warszawa 2004, s. 89.

106 Ibidem, s. 83.

107 Ibidem, s. 90.
} 
Wróćmy jednak do filmu, ponieważ muzyczna narracja w tej jego części wyraźnie się zagęszcza. Podczas wizyty Eriki w sex shopie Andante Schuberta po kilku minutach milknie, ale muzyka opuszcza filmową akcję tylko na chwilę, ponieważ zanim jeszcze Erika opuści jedną z kabin porno, przez głosy i jęki z filmu zaczyna przebijać się inny utwór Schuberta pieśn Im Dorfe, zaś po przejściu montażowym okazuje się, że śpiewa ją jeden ze studentów podczas lekcji z Eriką. Z sex shopu wracamy zatem do konserwatorium równie płynnie, jak wcześniej wyszliśmy z granego tam koncertu (Haneke wyraźnie intensyfikuje w tym momencie filmu obrazowo-muzyczną metaforykę, nadchodzi bowiem moment wprowadzenia nas w sedno opowiadanej historii). Charakterystycznym motywem dźwiękowym w Im Dorfe są głucho dudniące akordy fortepianu akompaniującego śpiewowi tenora, i to dudnienie zostaje połączone - kolejny, tym razem drobny, ale treściowo wydajny zabieg reżysera - z pukaniem do drzwi. Lekcja zostaje raptem przerwana i wchodzi Walter, który mimo reprymendy Eriki („W szkole muzycznej nie przerywa się zajęć!”) oświadcza, że chciałby zostać jej studentem. Jest to jeden $\mathrm{z}$ głównych punktów zwrotnych $\mathrm{w}$ filmie.

Od tego momentu akcja filmu rozdziela się dwa wątki. W jednym widz poznaje kolejne epizody z tajemnego życia erotycznego Eriki Kohut (wizyty w samochodowym kinie drive-in, gdzie masturbując się, podgląda pary; a także akty samookaleczania swoich części intymnych), które łączy jedno: dojmująca samotnośćc ${ }^{10}$. W drugim natomiast możemy obserwować Waltera i jego kolejne kroki, by zbliżyć się do fascynującej go kobiety. To uczucie może być dla Eriki ostatnią szansą na wyrwanie się z sadomasochistycznej pułapki oraz chorobliwej zależności od matki, ale wiemy już, jak wiele będzie ją kosztowało ewentualne otwarcie się na miłość. Temu wszystkiemu - czyli wydarzeniom, które możemy oglądać, oraz ukrytym myślom i uczuciom bohaterów - uważnie asystuje muzyka.

Scena egzaminu wstępnego Waltera do konserwatorium znakomicie ukazuje całe zniuansowanie sytuacji. Młody Klemmer prezentuje komisji, w której jest też pani Kohut, kilka kompozycji - w filmie zostają one

108 „Erika nie znosi bliskości i fizycznego kontaktu, ulgę przynosi jej podglądanie innych i rytuały sadomasochizmu. Największe wrażenie robi scena, w której pani profesor siada nad brzegiem wanny, aby "zabawić się« w przecinanie żyletką warg sromowych, podczas gdy jej matka krząta się za ścianą przy kolacji”. G. Arata, op. cit. 
montażowo połączone w jeden utwór, na tle którego rozgrywa się dramat wahania Eriki (wie ona, że przyjęcie Waltera będzie oznaczało dalsze kontakty z chłopakiem). Klemmer zaczyna od utworu Arnolda Schönberga (jest to Klavierstücke op. 33b, który miał zagrać na domowym recitalu, ale po rozmowie $z$ Eriką zmienił zdanie), a racjonalnie wykoncypowana, jak najdalsza od romantycznej egzaltacji struktura tej kompozycji dobrze oddaje charakter Waltera. Potem Klavierstücke płynnie - i dla kogoś, kto nie zna tych utworów, w zasadzie niedostrzegalnie - przechodzi w Preludium nr 5 Sergiusza Rachmaninowa, który choć był rówieśnikiem Schönberga, muzycznie reprezentował raczej poprzednią epokę z jej postromantycznym bagażem patosu i sentymentu. Kamera obserwuje na początku naprzemiennie grającego Waltera i słuchającą Erikę, lecz od rozpoczęcia utworu Rachmaninowa skupia się głównie na twarzy Eriki - jakby jej mimika była swoistą partyturą muzyki, którą słyszymy. Kiedy chłopak przechodzi (znów bez cięcia taśmy, jakby to była jedna kompozycja) do trzeciego utworu, czyli do Scherza z Sonaty A-dur Franza Schuberta, emocje widoczne na twarzy pianistki są tak silne, że nie budzą wątpliwości co do dwóch rzeczy: po pierwsze, że Walter gra znakomicie, a po drugie, że utwór porusza Erikę Kohut znacznie głębiej, niż mogłyby sięgnąć techniczne zagadnienia wykonawcze lub zasady kompozycyjne.

Chwilę później odbywa się narada komisji i wszyscy członkowie wyrażają zachwyt grą Klemmera - poza Eriką, która się sprzeciwia, uporczywie mnożąc zastrzeżenia natury technicznej („fanfaronada” łamiąca akademickie reguły gry) oraz ze zjadliwą ironią komentując decyzję o wstąpieniu do konserwatorium („Nie wzbogacę artystycznej natury ani wirtuozerii pana Klemmera"). Wiemy oczywiście, że opór Eriki wynika z innych przyczyn (gra chłopaka niewątpliwie znalazła jej uznanie), więc kiedy w końcu dostrzegamy na wywieszonej kartce $\mathrm{z}$ nazwiskami przyjętych kandydatów nazwisko „Walter Klemmer” - kamera długo odwleka tę chwilę, celebruje najazd na drzwi sekretariatu - jest to oznaka kapitulacji Eriki. Zapowiedź eskalacji jej napięcia i lęku, ale także budzenia się nadziei na miłosne spełnienie.

To burzliwe skonfliktowanie erotycznego pragnienia ze strachem i poczuciem winy dochodzi do głosu w kilku momentach filmu, owocując albo odruchami masochistycznymi, albo agresją wyładowywaną na innych. Ten drugi przypadek widzimy, kiedy Erika przyłapuje jednego ze swoich uczniów na oglądaniu z kolegami czasopism pornograficznych w kiosku, 
po czym „mści się” na nim (i poniekąd także na sobie samej) podczas lekcji w konserwatorium. Pretekst i fundament do wyrażenia moralnego oburzenia pianistka znajduje w zasadach muzycznych. Zaczyna od wytykania uczniowi błędów w grze („Nie eksponuj nut drugoplanowych! Trzymaj się głównej linii!”), a potem przekierowuje swój gniew, łącząc oba wątki muzyczny z seksualnym („Co cię pchnęło do muzyki? Twój malutki talent? Zapewniam cię, że nie warto. Przygrywaj striptizerce i nie marnuj mojego czasu”). Jednak z szyderstw wynika, że nawet taki przypływ „moralnego niepokoju” nie uwalnia Eriki od poczucia własnej winy („A może kobiety to świnie, bo robią świnię z ciebie?").

Widzimy zatem, że muzyka pełni w życiu Eriki Kohut rolę specyficznej ostoi moralnej czy też etycznej przeciwwagi dla grzesznych uczynków. Ale to nie wszystko, ponieważ wydaje się ogarniać sobą każdy poziom życia pianistki. Kiedy Erika słucha Schuberta granego przez ucznia, słyszymy jej komentarz do wykonywanego akurat fragmentu partytury („Śnią o niezdobytym, upajają się dobrem i złem, a nazajutrz wszystko znika - tu pojawia się ironia!”) i wiemy, że zarówno utwór, jak i interpretacyjne wskazówki dotyczą jej własnego życia. Kiedy za moment słyszymy harmoniczną zmianę w utworze, też towarzyszy jej czujnie wychwycona interpretacja („To rytm upartego mieszczanina"), za którą stoi własne życie wykładowczyni gry na fortepianie, tkwiące w kleszczach sztywnego, wiedeńskiego mieszczaństwa.

Muzyka ma aż taką moc, więc czasem działa jako strażnik moralności (na pierwszej lekcji Walter słyszy stanowcze: „Żadnego Schuberta, tylko Schönberg!”, wypowiedziane tonem, jakim dziewczyna broni się przez rozbieraniem na pierwszej randce), ale czasem jej obosieczne ostrze tnie $\mathrm{w}$ przeciwną stronę. Pokazuje to jedna $\mathrm{z}$ najważniejszych scen filmu - ta, w której Erika zakrada się do szatni i wsypuje do kieszeni swojej uczennicy szkło z potłuczonej szklanki, by okaleczona dziewczyna nie mogła grać, choć zbliża się najważniejszy występ w jej karierze. Na auli konserwatorium młoda pianistka ma akompaniować tenorowi śpiewającemu pieśni Franza Schuberta, ktoś musi przewracać jej nuty i wypada (niestety!) na Waltera, który wykonuje wobec dziewczyny serdeczny gest pomocy. Gest ten jest na tyle mało znaczący, że dostrzegają go tylko jedne $\mathrm{z}$ obecnych na auli par oczu - oczy Eriki Kohut. Para studentów zaczyna wykonywać utwór. Walter przewraca kartki, wszyscy słuchają, ale są na auli uszy, dla których muzyka Schuberta znaczy coś więcej niż dla innych - uszy Eriki Kohut. 
Kamera zatrzymuje się na twarzy Eriki w długim ujęciu (Haneke z premedytacją stosuje statyczne ujęcia, wyzwalając u widza inny rodzaj skupienia niż ten wymagany przez telewizję czy popularne kino hollywoodzkie ${ }^{109}$ ). Emocje narastają w delikatnych drgnieniach jej ust tyleż silnie, co niemal niedostrzegalnie (Grażyna Arata uchwyciła paradoksy kreacji Isabelle Hupert, pisząc o „szokującej subtelności jej ekranowej interpretacji”"110), kiedy równocześnie widzi siedzącego obok dziewczyny Waltera (jeszcze nie wie, czy go kocha, ale już jest o niego zazdrosna, jakby zazdrość była forpocztą miłości) i słyszy pieśń Der Wegweiser Franza Schuberta (której narrator, wędrując nieuczęszczaną ścieżką w rytm naśladującego zmęczone kroki fortepianu, trafia na zaśnieżone, górskie bezdroża i tam, pogrążony w rozpaczy, pragnie samotnie umrzeć). To połączenie - nadziei na spełnienie z Walterem, zagrożonej w tym momencie przez inną kobietę, oraz dramatycznej pieśni o osuwaniu się w samotność - działa jak zapalnik: Erika nagle wychodzi z sali. Potem jest sama, patrzy na nią tylko kamera, więc w szatni może dopuścić się skrajnej podłości, która jest aktem zazdrości i zemsty, ale też dowodem siły sprawczej muzyki.

Kiedy Erika wraca do auli, tenor śpiewa już kolejną pieśń Schuberta ćwiczone wcześniej na lekcji Im Dorfe, w którym bohater, idąc nocą przez wieś i słuchając szczekania psów na łańcuchach, szydzi z marzeń i snów mieszkańców mijanych domów, ponieważ dobrze wie, jak bardzo te marzenia są płonne. Większość studentów na auli mogła nie znać tekstu pieśni

109 „Christopher Sharrett: Sprawia pan wrażenie wielbiciela długich ujęć. Jest mnóstwo statycznych kadrów w pańskich filmach [...] i wiele takich ujęć twarzy Eriki [...]. Michael Haneke: Możliwe, że ma to związek z przekazem telewizyjnym. Telewizja zmienia nasz sposób oglądania. Przyspiesza przyswajanie obrazów. Na przykład reklamy w tym medium. A im szybciej coś jest pokazywane, tym mniej jesteśmy zdolni dostrzec przedmioty w ich fizycznej realności i tym bardziej stają się one uwodzicielskie. Im mniej realny jest obraz, tym szybciej kupujemy towar, jaki nam prezentuje. Oczywiście, ten typ estetyki zyskał wyższą rangę w kinie komercyjnym. Telewizja przyspiesza nasze doświadczenia, a my potrzebujemy czasu, by pojąć to, co widzimy. Ale współczesne media do tego nie dopuszczają". The World That Is Known, op. cit.

110 G. Arata, op. cit. 
Schuberta i słuchać go nieuważnie, ale przynajmniej jedna osoba znała te słowa świetnie i odbierała je nader osobiście - Erika Kohut.

Dochodzimy w ten sposób do kwestii miejsca i znaczenia w Pianistce cyklu pieśni Franza Schuberta Podróż zimowa. Schubert skomponował te dwadzieścia cztery utwory do wierszy niemieckiego poety Wilhelma Müllera. Właśnie stamtąd pochodzą obie śpiewane w filmie pieśni, a całość zakorzeniona w kulturze jako fundamentalne dzieło o samotności i poszukiwaniu własnej życiowej drogi ${ }^{111}$ - została w pewien sposób „nałożona”, niczym siatka kartograficzna, na mapę filmowych wydarzeń (do sposobu owego „nałożenia” jeszcze w powrócę). Aczkolwiek należy podkreślić, że Haneke pozostaje ironiczny i ostrożny w tym zabiegu, dzięki czemu ani znajomość cyklu, ani wiedza o tej korelacji nie jest przy oglądaniu filmu niezbędna ${ }^{112}$. Tu wracamy do - sygnalizowanej w pierwszej rozmowie Eriki i Waltera (kiedy to przy opowieści o Schumannie padły słowa: „Mówi pani o tym jak o własnym życiu") - do możliwości ponadczasowego duchowego pokrewieństwa między kompozytorami nieżyjącymi od dwóch stuleci a współczesnymi artystami, czyli do nałożenia typów psychicznych, czy wręcz indywidualnych cech charakteru Schuberta albo Beethovena (obaj dużą część życia spędzili w Wiedniu) na bohaterów Pianistki ${ }^{113}$.

W tym miejscu po raz kolejny przydatny okazuje się wątek polski, a mianowicie tom wierszy Stanisława Barańczaka zatytułowany Podróż zimowa

111 Rozliczne nawiązania do Winterreise odnajdziemy w dziełach sztuki z XIX i XX wieku, zarówno w literaturze (Czarodziejska góra Tomasza Manna), jak i w kinie (W obecności klowna Ingmara Bergmana).

${ }^{112}$ „Christopher Sharrett: Podróż zimowa Schuberta zajmuje centralne miejsce w Pianistce. Niektórzy dowodzą, że istnieje ścisły związek między Eriką a Schubertowskim wędrowcem $\mathrm{z}$ tego cyklu. I tu powraca ogólniejsze pytanie, na ile muzyka wyraża zdrową część świadomości Eriki, a na ile wzmacnia w niej procesy wyparcia. Michael Haneke: Niewątpliwie siedemnasta pieśń z cyklu jest w samym sercu filmowych wydarzeń i można ją widzieć jako motto - i życia Eriki, i tego filmu. Cały cykl wyraża ideę kroczenia nieuczęszczaną przez nikogo ścieżką - co wprowadza w film, jak sądzę, ironiczny kontekst”. The World That Is Known, op. cit.

113 „Rozpacz u Schuberta jest bardzo istotna i to rzutuje na nastrój filmu. Ktoś o tak ogromnych problemach jak Erika może czuć się jakby miał schubertowsko skomplikowaną artystyczną wrażliwość”. Ibidem. 
(wydany w 1994 roku), w którym poeta poddał pieśni z Schubertowskiego cyklu zabiegowi polegającemu na dopisaniu nowych tekstów do istniejącej muzyki; ściśle trzymał się przy tym jej schematów melodyczno-rytmicznych, ale treściowo stworzył całkiem nową jakośćl14. Koncepcja wybiega daleko poza parafrazę, mimo bogatej sieci nawiązań do oryginalnych tekstów, ponieważ w sferze poetyckiej Barańczak tworzy całkiem nową jakość. W oryginale ku tułaczce pchnęła bohatera pieśni nieszczęśliwa miłość (co było bliskie osobistemu doświadczeniu Schuberta), natomiast u Barańczaka motywy wędrówki są raczej religijne (jest koniec XX wieku, lecz chociaż Bóg - jak obwieścił Nietzsche - jest martwy, zaś jego obowiązki - jak ustalił Freud - przejęło superego, to wciąż nie przestaje być potrzebny). Dosłowna u Müllera zima, przez której realne śniegi brnie narrator, u polskiego poety staje się metaforą, a jej trzaskający mróz może być mrozem - do wyboru - egzystencjalnym lub politycznym (wszak komunizm w Polsce, w momencie publikacji tomu, dopiero co się skończył). Zabieg dokonany przez Barańczaka - i skonfrontowany z odbiorcą literackim, a później także muzycznym ${ }^{115}$ - bywa nazywany współcześnie „stylizacją intersemiotyczną” (jako że muzyka i literatura to dwa odrębne systemy znaków) ${ }^{116}$ albo w zgodzie $\mathrm{z}$ nazewnictwem ukutym jeszcze w XIX wieku - kontrafakturą ${ }^{117}$,

114 „Wiersze zawarte w tym zbiorze są, z jednym wyjątkiem, utworami oryginalnymi - n i e przekładami liryków romantycznego poety Wilhelma Müllera [...]. Choć związek między moimi utworami a muzyką Schuberta jest bardziej intymny i ścisły, moją ambicją było napisanie takich tekstów, które można byłoby zaśpiewać do określonej melodii, a zarazem - przeczytać można również w oderwaniu od muzyki, jako samodzielne wiersze". www.wydawnictwoa5.pl/Podroz-zimowaWiersze-do-muzyki-Franza-Schuberta;s,karta,id,174 [dostęp: 30.05.16].

115 Cykl wierszy wykonali w 1994 roku w formie regularnych, zaaranżowanych na głos i fortepian pieśni (odśpiewanych z szacunkiem dla schubertowskiej tradycji wykonawczej) Jerzy Artysz i Katarzyna Jankowska w sali koncertowej Polskiego Radia w Warszawie. Część z utworów trafiła potem na płytę opublikowaną przez magazyn „Studio”.

116 A. Hejmej, Stuchać i czytać: dwa źródła jednej strategii interpretacyjnej. „Podróż zimowa” Stanisława Barańczaka, „Pamiętnik Literacki” 1999, z. 2.

117 M. Poprawski, Muzykologiczne aspekty interpretacji „Podróży zimowej” Stanisława Barańczaka, www.demusica.pl/cmsimple/images/file/poprawski_muzykalia_5_1.pdf [dostęp: 30.05.16]. 
czyli dopisaniem nowego tekstu do wcześniej istniejącej muzyki (co było popularną praktyką u artystów średniowiecznych i renesansowych).

Trzymając się tej drugiej definicji i jej historycznych uwarunkowań, warto przypomnieć, że - przy zachowaniu całkowitej integralności muzyki i wierności jej zapisowi - kontrafaktura pozwalała na zmianę sposobu ekspresji oraz aury utworu, co w realiach średniowiecza czy renesansu pozwalało na przenoszenie go ze sfery sacrum do sfery profanum lub w przeciwną stronę. Służyło to twórcom do podejmowania wyrafinowanej gry z konwencjami artystycznymi, społecznymi czy religijnymi, co często kończyło się wzburzeniem publiczności i skandalem.

Tom Barańczaka nawiązuje także do tych cech kontrafaktury, ponieważ zachowując pozory uwspółcześnionej, ale spolegliwej wobec oryginału parafrazy ${ }^{118}$, po pierwsze, kwestionuje rozmaite stereotypy dotyczące podejścia do dawnych dzieł (w tym - nienaruszalności ich charakteru), po drugie natomiast, traktując $\mathrm{z}$ atencją kompozycje Schuberta, podejmuje ironiczny spór z romantyczną poezją Müllera, a więc poniekąd z samym duchem romantyzmu (który po stu pięćdziesięciu latach wciąż pozostaje niepokojąco żywy w powszechnym odbiorze literatury). Jak zauważył Marcin Poprawski: „Podróż zimowa przenosi muzykę Schuberta ze sfery profanum do sacrum, jako że w wierszach Barańczaka wyraźnie ujawnia się kluczowy ton modlitwy, którego prawie nie ma u Müllera" ${ }^{\prime 19}$. Z drugiej strony, ktoś słusznie może zwrócić uwagę, że możemy rzecz rozumieć odwrotnie: muzyka Schuberta, traktowana przez koneserów jak świętość, zostaje poprzez „wykreślenie” niemieckiego tekstu wewnętrznie rozbita i ulega swoiście rozumianej profanacji.

Oczywiście, Pianistka nie jest tak rozumianą kontrafakturą (choć film jako gatunek jest niewątpliwie systemem znaków, więc umożliwia taki zabieg $\left.^{120}\right)$. Jednak intersemiotyczny charakter dzieła Hanekego wynika

118 „[Barańczak] rozsiewa różne aluzje tematyczne na przestrzeni całego cyklu, czyniąc z nich odniesienia ogólnie pasujące do aury i nastroju Müllerowskiego cyklu”. Ibidem.

119 „Zgodność ta jest łatwo dostrzegalna, ale zarazem tylko powierzchniowa, jako że podszyta Barańczakową ironią, polemiką, sprzeciwem i niską oceną wartości poezji Müllera! A podobieństwa wcale nie służą tu afirmacji”. Ibidem.

120 „Kinematografia, podobnie jak inne sztuki, jest szczególnym systemem znaków". B. Eichenbaum, Problemy stylistyki filmowej, [w:] Estetyka i film, red. A. Helman, Warszawa 1972, s. 60. 
z wykorzystania jej elementów. Film zawiera niektóre cechy kontrafaktury: zmianę tonacji, wielopoziomowy dialog z oryginałem czy wreszcie godzącą w społeczne zasady nieobyczajną naturę, która pociąga za sobą skandaliczną aurę. W przypadku Pianistki ta aura powstała wokół obscenicznych upodobań i zachowań bohaterki, których ocena - dominująca zarówno w spontanicznych reakcjach publiczności ${ }^{121}$, jak i w wielu recenzjach i dyskusjach krytyków ${ }^{122}$ - po pierwsze, spychała na dalszy plan inne problemy poruszone przez film, po drugie natomiast, kierowała dyskusję w kierunku stereotypowej dychotomii kultura/natura, ludzkie/zwierzęce ${ }^{123}$.

Wyrazy oburzenia albo skwapliwie umoralniający ton wielu recenzji świadczą o tym, że w Pianistce zostały dobrze uchwycone (czy też: zachowały się) prowokujące i wywrotowe właściwości kontrafaktury. Chociaż można by pozostawić obronę filmu oraz uzasadnienie drastycznych scen samemu reżyserowi (który wielokrotnie i do znudzenia, także własnego, opowiadał w wywiadach o swoim stosunku do pornografii, między innymi o niszczącym ludzką psychikę wpływie masowych mediów, o utowarowieniu obsceniczności czy pornografizacji przemocy ${ }^{124}$ ), to zdecydowanie lepiej poszukać uzasadnienia wewnątrz, a nie na zewnątrz filmu, czyli pozwolić dziełu, by broniło się samo. I właśnie tak się stanie, jeżeli przede wszystkim przyjrzymy się (i przysłuchamy) Pianistce jako celowemu zetknięciu dwóch systemów znaków, czyli „nadpisaniu” współczesnych kinowych obrazów

121 „On jest chory! - usłyszałem po festiwalowym seansie”. T. Sobolewski, Haneke. Wściekły i podstępny, op. cit. „Dla zaszokowania widzów i zainteresowania ich problemem postanowił nie unikać obsceniczności, ukazując z odpowiednią dosadnością sadomasochistyczne skłonności Eriki”. K. Wolanin, op. cit.

122 „Ale to nie jest rafinada, to jest zejście do rynsztoka!”. Z. Kałużyński, T. Raczek, Pojedynek z seksem, „Wprost” 2001, nr 47.

123 „To jest problem bohaterki: przepaść między kulturą, która jest jej światem, a zwierzęcością, bydlęcością, ohydnością seksu. [...] To jest konflikt między tym, co w człowieku duchowe, i tym, co zwierzęce. Bo człowiek jest potworem, panie Tomaszu". Ibidem.

124 „Pornografia sama w sobie nie jest dla mnie interesująca, nie mam ochoty jej atakować, szkoda by mi było czasu, żeby robić film przeciwko niej. Zgodnie z moją definicją pornografii: Pianistka może być odebrana jako film antypornograficzny, ale Funny Games jest w takim razie o wiele bardziej antypornograficzny!”. Era wilków, op. cit. 
oraz skrajnie drastycznej historii na powstałą półtora wieku wcześniej muzykę. Muzyka ta jest świadectwem epoki, której moralno-społeczny gorset był ciaśniejszy niż dziś, a jednak nostalgia za owym „dawnym” porządkiem (klasycznie zdyscyplinowanym jak muzyka, która go reprezentuje) wciąż pozostaje żywa i powszechna.

Takie spojrzenie pozwala zobaczyć w filmie nie obraz patologicznych relacji - rodzinnych i damsko-męskich - na tle opresyjnego austriackiego mieszczaństwa (znamienne są różnice między filmem, znajdującym osobliwe zrozumienie $^{125}$ dla najgorszych nawet cech bohaterów, a pełną oskarżycielskiej furii powieścią Elfriede Jelinek) oraz nie opowieść o melodramacie w obscenicznych realiach (choć jeśli jest to obscena w znaczeniu zaproponowanym Jeana Baudrillarda, to rzuca ona istotne światło w mroki duszy bohaterów filmu ${ }^{126}$ ). Zamiast tego Haneke pokazuje przede wszystkim historię ujawniania się indywidualnej ludzkiej prawdy, która napotyka na opór społeczny (tym bardziej jeżeli jest to prawda o kobiecie). Bez względu na to, czy będziemy w XIX-wiecznym Wiedniu, czy we współczesnej liberalnej Europie.

Wykorzystanie muzyki sprzed dwóch stuleci i specyficznie „kontrafakturowe" dopisanie do niej nowej historii, celowo drastycznej i bulwersującej, pokazuje, że z prawdą Eriki nie godzą się, po kolei: jej matka (traktująca kobietę jak nastolatkę), Walter (który na śmiałe odsłonięcie się Eriki reaguje agresją i pogardą) i wreszcie sam widz (wobec czego zasadne staje się pytanie, czy nie jest on - tak jak w przypadku Funny Games - właściwym bohaterem filmu).

Bohaterka Pianistki, prowadzona przez muzykę z całkiem innej epoki, błąka się po hałaśliwych ulicach Wiednia (między opresyjnym domem, rygorami konserwatorium a perwersyjnym światem sex shopów) niczym wędrowiec z Podróży zimowej - raptem przeniesiony z wystudiowanych romantycznych realiów w trywialną współczesność. U obojga trauma odrzucenia

125 Zasłyszane przez Tadeusza Sobolewskiego w kinowej sali „On jest chory!” jest spowodowane poniekąd właśnie podejściem Hanekego, dalekim od moralnego osądzania.

126 „Obsceniczność zawiera element transgresji, prowokacji czy perwersji. Igra z wyparciem za pomocą fantazji, których tematem jest przemoc.” J. Baudrillard, O uwodzeniu, tłum. J. Margański Warszawa 2005, s. 32; zob. też: P. Zawojski, op. cit. 
graniczy z pewnością, że to odrzucenie będzie się powtarzać: zawsze znajdzie się jakiś mistrz piekarski (za którego wyszła ukochana Franza Schuberta) albo normalna dziewczyna (którą na pewno szybko znajdzie sobie Walter). Jednak w filmie - do połowy seansu - owa granica pewności jeszcze nie zostaje przekroczona.

Przyjrzyjmy się w tym kontekście scenom dwóch pierwszej lekcji, które Walter bierze u nowej profesorki fortepianu. $\mathrm{Na}$ „dzień dobry” wygłasza ona stanowczy komunikat: „Żadnego Schuberta, tylko Schönberg”, co niesie dwojakie znaczenie: po pierwsze, ma utemperować „romantyczne” gesty chłopaka skierowane ku niej, po drugie natomiast, skierować jej własne myśli na tory raczej „schönbergowskie” - intelektualne, skrupulatne, ustrukturyzowane jasno i klarownie - niż „schubertowskie”, czyli emocjonalne i niosące nazbyt wiele biograficzno-miłosnych podtekstów. Jednak próba oczyszczenia ich relacji, zaprowadzenia porządku uczeń - nauczyciel, okazuje się nieskuteczna.

Ta muzyczna alternatywa - albo Schönberg, albo Schubert - okazuje się symbolicznym rdzeniem filmowych wydarzeń. Niedługo później dochodzi bowiem do kolejnego zwrotu akcji: pierwszego fizycznego zbliżenia między Eriką i Walterem w toalecie konserwatorium. Jest to jedna z przełomowych scen filmu, o dużej intensywności emocjonalnej ${ }^{127}$ (na plakat promujący film trafił kadr z kompulsywnym pocałunkiem na podłodze). Walter dąży do „normalnego” seksualnego kontaktu, ale Erika nie potrafi się przełamać i ulec standardowym w takiej sytuacji emocjom, rzec można: „schubertowskim” (z całym romantycznym bagażem stereotypów idących za muzyką Schuberta), pozostającym w kręgu społecznie akceptowanej „seksualnej tonalności”'28. Kobieta została przeprogramowana (przez długo-

127 „Świadomość okaleczonego losu, ukrywana za cynizmem i samotną konsumpcją seksualnych podniet, wybucha w filmie kilka razy, działając na zasadzie dynamitu". G. Arata, op. cit.

128 „Tonalność, muzyka tonalna - termin opisujący konwencje harmoniczne większości zachodniej muzyki [...] od wieku osiemnastego do teraz. Muzyka tonalna jest zorganizowana wokół centrum nazywanego toniką i skali, której tonika jest podstawą. Nazywa się ją również »harmoniką funkcyjną lub »harmonią klasyczną"”. Kultura dźwięku. Teksty o muzyce nowoczesnej, red. Ch. Cox i D. Warner, tłum. J. Kutyła, Gdańsk 2010, s. 510. 
trwałe oddawanie się perwersyjnym praktykom) na skrajnie wyrafinowany tryb doświadczenia seksualnego, związany z kontrolą, bólem, dominacją, wykraczający poza utrwaloną „tonalność” relacji erotycznych - a zatem swoiście „schönbergowski” (jako że Schönberg to jeden z prekursorów atonalności w muzyce ${ }^{129}$ ).

Złożona psychika Eriki Kohut i jej skrajnie nietypowe potrzeby (zamiast standartowego seksualnego zbliżenia, nakłania Waltera do poddania się aktowi dominacyjnej masturbacji) to produkt nie tylko pornoedukacji oraz sadomasochistycznych praktyk odreagowywania samotności i upokorzenia ${ }^{130}$, ale być może także rodzaj „skrzywienia zawodowego”, czyli efekt lat pracy nad wyrafinowanym materiałem muzycznym i wpajania go uczniom w skrajnie chłodny, intelektualny sposób. W słynnej scenie z Pianistki jesteśmy zatem świadkami nie tylko nieudanej rozbieranej randki prostego studenta politechniki („od recitalu utkwiła mi pani w głowie jak śruba w nakrętce - przepraszam za to techniczne porównanie”) z profesorką muzyki, zanurzoną w świecie fortepianowych arcydzieł (bez odtrutki w postaci spełnionej kariery wykonawczej ${ }^{131}$ ), ale także symbolicznego spotkania akceptowanej społecznie kulturowej tradycji z awangardą, która ujawnia swoją „bulwersującą” moc. Tak czy owak, pragnienia Eriki zostały po raz pierwszy ujawnione - puszka Pandory została otwarta.

Podczas drugiej lekcji Waltera u Eriki - już po zbliżeniu w toalecie, ale przed jakąkolwiek werbalną kodyfikacją ich związku - na tle lirycznych

129 „Atonalność, muzyka atonalna - termin ten opisuje szerokie spektrum stylów kompozycyjnych, które nie opierają się na konwencjach harmonii tonalnej, a zwłaszcza nie organizują wysokości dźwięków wokół ośrodka tonalnego”. Ibidem, s. 501.

130 „Seks w La Pianiste ma formę kuriozalną i bolesną, zdecydowanie antykonformistyczną i daleką od jakichkolwiek śladów romantyzmu. Jest odbiciem i kompensacją wewnętrznych frustracji i afektywnego okaleczenia bohaterki, u której zduszono potrzebę ciepła i czułości, zastępując je strukturami dominacji”. G. Arata, op. cit.

${ }^{131}$ „A może, panie Zygmuncie, ona poszukuje w seksie tego stopnia wyrafinowania, który osiąga w sztuce, w muzyce? Może jest niezdolna do zwykłego seksu w rodzaju - kocham cię, pocałuj mnie, chodźmy do łóżka”. Z. Kałużyński, T. Raczek, op. cit. 
dźwięków Andantina z Sonaty A-dur Schuberta (a zatem Schönberg przegrał w symbolicznym pojedynku) obserwujemy walkę, jaką Erika toczy ze swoimi pragnieniami. Walczy, przywołując na pomoc fachową wiedzę („Wskazówki Schuberta idą od szeptu do krzyku”), a także inspirowaną przez muzykę intuicję $\mathrm{w}$ drążeniu zakamarków kompozytorskich dusz („Brahms napisałby con intimissimo sentimento"). Ma także inną broń: wsparte wiedzą szyderstwo („Jak pan wie, Schubert był dość brzydki, a pana chroni ładna buźka"). W końcu jednak Erika wręcza Walterowi skrupulatny wykaz jej miłosnych życzeń (w istocie jest to bulwersujący katalog sadomasochistycznych czynności), który chłopak ma otworzyć dopiero, kiedy będzie sam. W takim sposobie rozegrania miłosnej partii znowu spotykają się dwie osobowości Eriki Kohut. Jedna to wykładowczyni w konserwatorium, zagrzebana w katalogach opusów, ściśle przestrzeganych muzycznych tempach i nastrojach (allegro, largo, cantabile), zaś druga to wielbicielka pornografii z jej niezmordowanym katalogowaniem ludzkich zachowań seksualnych, aby każde pragnienie mogło trafić na odpowiednią sklepową półkę (BDSM, pissing, dogging). Erika przenosi cechy obydwu swoich osobowości na miłosną relację z Walterem, przekazując mu listę precyzyjną jak zapisy w partyturze i wypunktowaną jak handlowe zamówienie.

Walter czuje, że gardło Eriki ściskają emocje, lecz pianistka mówi stanowczo: „Zrozum, że ja nie mam uczuć. Nigdy nie zatriumfowałyby nad moją inteligencją". Do pewnego stopnia jest to prawda, ponieważ potrzeba zdystansowanej kontroli (także w rzekomo czysto emocjonalnej grze w uwodzenie ${ }^{132}$ ) i narzucania skodyfikowanych rygorów (choćby samemu miało się nim boleśnie ulegaćl ${ }^{133}$ ) jest u niej silniejsza niż jakiekolwiek spontaniczne uczucia. Na zakończenie tej sceny Erika nakazuje: „A teraz zabierz się za Schuberta - tylko to wolno ci w tym pokoju", zaś Walter wraca do Andantino, którego subtelna

132 „Przede wszystkim muszę uświadomić samemu sobie to, że cała ta historia jest fikcyjną grą". S. Kirkegaard, Dziennik uwodziciela, tłum. S. Lack, M. Bienenstock, Warszawa 2009, s. 430.

133 „Osobnik perwersyjny jest skrajnie podejrzliwie nastawiony do uwodzenia i stara się je skodyfikować. Stara się ustalić jego reguły, sformalizować je w tekst, wyrazić je w pakcie. W ten sposób łamie podstawową regułę, regułę tajemnicy". J. Baudrillard, op. cit., s. 124. 
melodia jest przeciwstawiona obserwowanej przez kamerę kopercie z ukrytymi pragnieniami.

Co ciekawe, jest to ostatni moment, kiedy muzyka w Pianistce tak efektywnie angażuje się w filmową narrację - do sceny erotycznego zbliżenia a potem, kiedy wypadki toczą się już siłą emocjonalnej bezwładności (ku klęsce bohaterki, ukazaniu się odmiennego oblicza Waltera i krachowi ich uczucia), kompozycje odchodzą na drugi plan, w tło wydarzeń. Ostatniej scenie filmu (kolejnemu statycznemu ujęciu) towarzyszy jedynie szum ulicznego ruchu otaczający wiedeńskie konserwatorium.

O tym, dlaczego muzyka milknie, Michael Haneke opowie w innym filmie.

\section{MIŁOŚĆ, CZYLI DLACZEGO MUZYKA MILKNIE}

Jeszcze dłuższe, pozbawione muzyki, statyczne ujęcie rozpoczyna film Miłość. Przez kilka minut kamera obserwuje w filharmonii publiczność czekającą na fortepianowy recital, a pary głównych bohaterów - choć grają ich znani, świetnie rozpoznawalni aktorzy - przy pierwszym oglądaniu filmu widz może w ogóle nie wychwycić. Jest to typowe dla Hanekego, wystawiające cierpliwość widza na próbę, szerokokadrowe ujęcie ${ }^{134}$, symulujące nieobecność reżysera: kamera sprawia wrażenie postawionej naprzeciwko widowni na stałe. W warstwie audio jest tak samo - wypełniają ją naturalne szmery, stuknięcia, strzępy głosów, których przedłużająca się (zdecydowanie ponad komercyjną filmową miarę) obecność pozwala tym dobitniej zabrzmieć pierwszym akordom Impromptu c-moll nr 1 Franza Schuberta.

Początkowo Impromptu brzmi w rzeczywistości diegetycznej: słuchane przez publiczność podczas koncertu. Charakterystyczny temat na początku utworu (łatwo wpadający w ucho niekoniecznie uzbrojone w muzyczną wiedzę) znakomicie pełni przy tym funkcję motywu otwierającego film. Po „antyromantycznym” szumie w prologu, słuchamy „romantycznej” melodii zapowiadającej późniejszy przebieg akcji. Niesie to za sobą także głębszy

134 „Scena otwierająca film (ze znakiem firmowym Hanekego - szerokokadrowym ujęciem zachęcającym widza, by zaczął analizować to, co widzi, w ten sam sposób, w jaki analizuje treść całego filmu) ukazuje parę w sali Théâtre des Champs Elysées na fortepianowym recitalu”. http://framescourer.blogspot.com/2012/11/ music-in-amour-2012.html [dostęp: 30.05.16]. 
sens, ponieważ - jak pamiętamy - w pierwszym ujęciu kamera w ogóle „nie dostrzega" bohaterów - są tylko statystyczną parą ludzi w tłumie (dwoma zajętymi krzesłami na sali, dwoma zakupionymi biletami, dwiema pozycjami w remanencie kasy po koncercie), a dopiero wypadki, które nastąpią, zaczną ukazywać Anne i Georges'a w coraz bliższej perspektywie - aż do tej najbardziej osobistej, najintymniejszej.

Ta intymność dotyczy zresztą tyleż samo rzeczywistości wewnątrz filmu (przez dwie godziny będziemy się z bliska przyglądać postępującej ciężkiej chorobie Anne, która po udarze będzie miała sparaliżowaną prawą część ciała i zacznie ulegać stopniowej psychicznej i fizycznej degradacji, ale także codziennemu poświęceniu Georges’a, który mimo podeszłego wieku zaopiekuje się żoną), co kontekstom pozafilmowym. Miłość jest bowiem zainspirowana losami 92-letniej ciotki reżysera, która dotknięta nieuleczalną chorobą, prosiła o odebranie jej życia ${ }^{135}$. Emocjonalne zaangażowanie Hanekego potwierdza fakt, że część sprzętów i obrazów z paryskiego lokum pary bohaterów to rzeczy prywatne, należące do reżysera, zaś urządzenie mieszkania jest wzorowane, miejscami z detaliczną precyzją, na mieszkaniu jego rodziców. Choć, oczywiście, przełożenie życia na dzieło nie jest aż takie proste ${ }^{136}$.

Otwierająca Miłość fortepianowa kompozycja Schuberta sięga jednak nie tylko w przyszłość, lecz także w przeszłość bohaterów. Najpierw mamy znany już chwyt z cięciem montażowym w warstwie obrazu, bez cięcia taśmy z dźwiękiem: Impromptu c-moll na koncercie trwa dalej, choć bohaterowie wracają już do domu, a frazy fortepianu są niezwykle płynnie

135 „Powiedziałem jej, że nie mogę jej pomóc, bo po pierwsze, poszedłbym do więzienia, a po drugie, nie byłbym w stanie tego zrobić - opowiada reżyser. - Potem ciotka próbowała popełnić samobójstwo, ale w porę zawiozłem ją do szpitala. Była na mnie zła. Dlaczego mi to zrobiłeś? - pytała. Dwa lata później udało jej się, odebrała sobie życie. Miłość to film dla niej”. Michael Haneke dedykuje "Miłość" ciotce, www.canalplus.pl/film/news-michael-haneke-dedykuje-milosc-ciotce_40195 [dostęp: 30.05.16].

${ }^{136}$ „Nie ukrywał, że inspiracją dla Miłości były zdarzenia z jego życia. Ale choć w paryskim studiu odtworzył mieszkanie swoich rodziców (z detalami, jak meble z lat 50., stereo $z$ lat 60.), podkreśla, że nie opowiada o doświadczeniach związanych $\mathrm{z}$ ich odchodzeniem". M. Sadowska, op. cit. 
zharmonizowane z kołysaniem autobusu i ruchem sylwetek pasażerów w kadrze. Scena jest zmontowana z podobną realizacyjną zręcznością jak ta $\mathrm{z}$ Pianistki, gdzie grane na próbie w konserwatorium Schubertowskie Andante towarzyszy bohaterce później w sex shopie, tyle że tu zostaje użyta o wiele dyskretniej, bez ambicji radykalnie metaforycznych, chociaż dla filmu znaczy równie wiele. W kilka chwil zostaje nam zasugerowane, jak głęboko może tkwić muzyka w świadomości Anny i Georges’a oraz jak ważną rolę będzie pełnić w dalszych wydarzeniach.

Po powrocie do domu odegrany na koncercie utwór dalej absorbuje uwage bohaterów, choć z punktu widzenia widza nie istnieje już w formie dźwiękowej (film wraca do realistycznej sfery i słyszymy, z detalami, odgłosy domowej krzątaniny). Anne, pomiędzy banalnym zdjęciem płaszcza i zrobieniem czegoś w kuchni, wyraźnie ożywionym głosem mówi: „Szesnastki w presto były nadzwyczajne - co za finezja! Nie sądzisz?” (dzięki temu dowiadujemy się, że bohaterowie nie są tylko parą starszych melomanów, ale mają znacznie więcej wspólnego z muzyką), na co Georges odpowiada retorycznym wobec entuzjazmu w głosie żony - pytaniem: „Jesteś z niego dumna?” (co wskazuje na więź łączącą Anne z młodym pianistą na koncercie). Tak samo jak w Pianistce, widzimy zatem, że Haneke prowadzi narrację za pomocą muzyki na dwa sposoby: po pierwsze, za pomocą jej „fizycznej” obecności, czyli słyszalności przez widza, po drugie zaś, za pomocą rozmaitych kontekstów, które dotyczą utworów, a które można umieści w sferze obrazu, dialogów, albo nawet w sferze domyślnej - ufając kulturowej wiedzy widza.

Jest wszakże też istotna różnica: pierwsza rozmowa o muzyce w Pianistce kiedy Erika opowiada Walterowi o losach Schumanna, nawiązując do własnych doświadczeń - niesie ze sobą bagaż „romantycznych” kontekstów (zawartych w słowach: „utrata zmysłów”, „katastrofa”, „zatracenie”, czy w końcu „zmierzch duszy”), które, jak wiemy, mają się niejako „powtórzyć” w filmowym „tu i teraz”, czyli w dramatycznym romansie, jaki wkrótce nawiążą bohaterowie. Natomiast pierwsza rozmowa o muzyce w Miłości w ogóle nie nawiązuje do „romantycznych” korzeni utworu Schuberta (słyszymy słowa „szesnastki” i „presto”, których suchy aspekt techniczno-wykonawczy jest zrównoważony nacechowanym uczuciowo słowem „finezja”) i odbywa się nie podczas iskrzącej wzajemną fascynacją rozmowy erotomanki z przystojnym studentem, lecz w banalnych pieleszach $\mathrm{u}$ pary starszych mieszczan. 
Co równie znamienne, w Pianistce po scenie domowego recitalu, na którym słyszymy granego na dwóch fortepianach Bacha, muzyka zaczyna coraz śmielej przejmować narrację, rozbrzmiewając często i asystując rozwojowi akcji szczególnie przez pierwszą godzinę filmu. Tymczasem w Miłości po odegranym na początku Impromtu Schuberta muzyka na prawie godzinę czyli niemal pół filmu - milknie.

Muzyka milknie, lecz to wcale nie znaczy, że reżyser zwalnia ją z narracyjnych obowiązków. Działanie muzyki, wskutek fizycznej, dźwiękowej „nieobecności”, staje bardziej dyskretne, subtelniejsze, dalekie od kinowych schematów (tak jak tytułowa miłość okazuje się daleka od powszechnych wyobrażeń). Pojawia się na przykład pod postacią przedmiotów (sprzętu stereo ulokowanego tak, że stanowi naturalne tło dla kilku kluczowych scen w filmie, albo książki o dyrygencie Nicolasie Harnoncourcie, który w latach 60. ubiegłego wieku - a więc w latach twórczej młodości obojga bohaterów - zrewolucjonizował myślenie o muzyce). Nawet fakt, że ucznia Anne gra autentyczny pianista, Alexandre Tharaud, potrafi nabrać metafilmowego znaczenia, jeżeli wiemy, że to Tharaud nagrał utwory na ścieżkę dźwiękową do Miłości. A soundtrack to szczególny, ponieważ - inaczej niż w komercyjnych produkcjach - na płytę nie trafiły całe utwory, ale ich urywki - dokładnie takie, jakie słyszymy w trakcie seansu ${ }^{137}$. Jest to przypadek zepsutej świadomie radości słuchania, aby doświadczenie nagłego ucichnięcia muzyki - która przecież nie znika wtedy z głowy - można było osiągnąć także po powrocie z kina do domu. Wtedy okazuje się, że jesteśmy blisko rozważań Carla Dahlhausa nad fenomenologicznymi aspektami trwania i odbierania muzyki, a także jego - istotnego z punktu widzenia niniejszej pracy - przeświadczenia o wielopoziomowości muzyki, skutkującej wielopoziomowością odbioru i interpretacji ${ }^{138}$. Pierwotnie wymyślony

137 „Kto zakupi soundtrack do Miłości Michaela Hanekego przed obejrzeniem filmu, może mieć wrażenie zabawnej pomyłki, jeżeli chodzi o podejście reżysera do muzyki. Nie w tym rzecz, że lista utworów jest niekompletna, bo mamy tu i Schuberta, i wybór bagateli Beethovena. Tyle że każdy utwór na płycie jest przerwany po krótkim czasie - nagłym cięciem albo słowami: »Wyłącz to«. (W roboczej wersji film miał tytuł Kiedy muzyka milknie)". Ryan Gilbey, op. cit.

138 „Dahlhaus rozważa także problem muzyki jako fenomenu audytywnego, przemijającego w czasie, ujmowanego w kategoriach fenomenologii. Podejmuje 
przez Michaela Hanekego tytuł dla filmu - Kiedy muzyka milknie - ma zatem konsekwencje wykraczające daleko poza fabułę.

Sposób, w jaki muzyka działa wewnątrz filmu, odpowiada, jak się zdaje, podejściu samego reżysera ${ }^{139}$. Miłość pod wieloma względami oglądamy jak film, który nie wyszedł spod ręki Hanekego: częściowo pozostały tu elementy jego stylu, ale przy znamiennym braku niektórych efektów, do jakich nas przyzwyczai1 ${ }^{140}$. Ta zmiana stylu Hanekego w Miłości - nieco podobna do wolty Davida Lyncha, kiedy wbrew postmodernistycznemu emploi nakręcił Prosta historię - ma oczywiście prawo budzić nieufność (wszak reżyser to podstępny gracz na emocjach widza, wytrawny szuler tasujący to, co widzialne i ukryte $\left.{ }^{141}\right)$, lecz potrafi też uwiarygodnić reżysera, który nie potrzebował, w chwili premiery Miłości, potwierdzać ani swojej

m.in. krytyczną dyskusję z koncepcją Romana Ingardena, podważając jego tezę o jednowarstwowej strukturze muzyki i twierdząc, że "Tak jak bezowocna jest próba policzenia warstw - nie da się zaprzeczyć, że zdanie o jednowarstwowości jest błędne«". A. Jarzębska, Dialektyczny dyskurs Dahlhausa, „Ruch Muzyczny” 2009 , nr 6.

139 „Nieprzypadkowo film nosi tytuł Miłość, ale odkrycie prawdziwego znaczenia tego słowa u niejednego widza wywoła uczucie dyskomfortu, będzie zaskoczeniem, a dla wielu - szokiem. Haneke jest czulszy niż zwykle, ale bynajmniej nie sentymentalny". M. Sadowska, op. cit.

140 „Miłość wygląda jak film Hanekego - tak pod względem kompozycji długich, w większości statycznych kadrów, jak i sensu opowieści - ale nie ogląda się jej jak filmu Hanekego. Austriacki reżyser zawsze stosował pewnego rodzaju brutalizm, forsował przyjętą przez siebie tezę w taki sposób, jakby był przekonany o jej słuszności, nie znosząc choćby cienia sprzeciwu. Często wymierzał widzowi precyzyjnie wycelowane kopniaki, zwykle za pomocą przepełnionych przemocą scen, z góry zaplanowanych jako szokujące. Miłość pozbawiona jest tego typu zagrań, pozbawiona jest też pewnego rodzaju napuszenia”. G. Fortuna, op. cit.

${ }^{141}$ „Ja sama do Miłości podchodzę nieufnie, może dlatego, że nie spodziewałam się takiego filmu po twórcy Ukrytych, Wideo Benny'ego, Pianistki. [...] Zaskakująco łagodnego wobec widzów i bohaterów, choć czyniącego tematem śmierć. Do tego ów gołąb, jak skradający się przez okno kicz (»Gołębi puch - perfidny kicz« śpiewał kiedyś nie bez racji Lombard)”. M. Sadowska, Martwa natura. Z gołębiem, www.canalplus.pl/film/blog-malgorzata-sadowska-martwa-natura-zgolebiem_961_11 [dostęp: 30.05.16]. 
wirtuozerii technicznej, ani błyskotliwej erudycji na polu artystycznym czy filozoficznym, natomiast wielu odbiorców jego filmów odpychała reżyserska maniera uparcie pesymistycznego moralizatora, a zatem w istocie - filmowego doktrynera ${ }^{142}$.

Co ciekawe, niektóre muzyczne wątki w Miłości wydają się nawiązywać do wydarzeń z poprzednich filmów reżysera (i ukazywać podobne sytuacje czy stany, acz w nieco innym świetle). Na przykład kiedy Anne i Georges’a odwiedza ich córka, Eva, słyszymy - przy okazji opowieści o tournée, na którym wykonują z mężem muzykę Johna Dowlanda - historię artystyczno-erotycznych perturbacji w ich związku. Dzieje burzliwego romansu męża ze skrzypaczką, zwieńczone próbą samobójczą kochanki, można odebrać jako cień kroniki wypadków miłosnych z Pianistki (tym bardziej że w roli Evy reżyser obsadził Isabelle Huppert - pytanie: ile w tym typowej dla Hanekego ironii?). Tymczasem Georges słucha opowieści córki ze stoickim spokojem, równie daleki od zdziwienia czy wzburzenia takim obrotem spraw w „artystycznym” małżeństwie, co od jakiejkolwiek oceny moralnej.

Wiemy, że Eva także jest muzykiem, ale poza tym jej relacje z rodzicami (a konkretnie z Georges'em, bo Anne leży już chora w łóżku) są raczej chłodne, pełne stonowanego dystansu zamiast spontanicznej serdeczności. Spora część krytyków, jakby wciąż tęskniąca za „dawnym” Hanekem, przedstawia to jako dowód, że reżyserowi nie stępił się pazur krytyki społecznej ${ }^{143}$

142 „Doceniając wszystkie wcześniejsze filmy Michaela Hanekego, zżymałem się niekiedy na wyraziście stawiane przezeń tezy, formułowane w stylu tak gwałtownym, że właściwie niedopuszczającym odrębnego zdania”. Ł. Maciejewski, op. cit. „Miłość Michaela Hanekego jest najlepszym filmem w karierze reżysera, którego rzemiosło doceniałem zawsze, ale którego moralizatorstwo często budziło moje wątpliwości (także na tych łamach). Tym razem efekciarskiego czarnowidztwa nie ma prawie wcale - zamiast niego Haneke staje twarzą w twarz z umieraniem jako ostateczną potwarzą natury rzuconą pod adresem ludzkiej godności”. M. Oleszczyk, Miłość, „Dwutygodnik” 2013, nr 2(101), www.dwutygodnik.com/artykul/4067-milosc-rez-michael-haneke.html [dostęp: 30.05.16].

${ }^{143}$ „Córka starszej pary także nie zna już sztuki włáciwego zachowania. Kiedy przychodzi do rodziców (a pojawia się nieczęsto), zaznacza swoją obecność wybuchami narcystycznego cierpienia. Epatuje zmęczonego ojca pełną wyrzutu, 
i nie wygasła pasja demaskatora mieszczańskiej obłudy ${ }^{144}$, ale można też dostrzec w rozmowie ojca $z$ córką coś wręcz przeciwnego: skryte za dystansem zaufanie (takie samo jak w relacji Georges’a i Anne), owocujące szczerością i spokojną otwartością ${ }^{145}$ - czyli relację stanowiącą zaprzeczenie charakteru związku Eriki z jej matką w Pianistce. Te dwie bohaterki reżyser pokazywał z bezlitosną przenikliwością, zupełnie inaczej niż w Miłości portretuje Evę i jej ojca ${ }^{146}$. Być może dlatego, że Haneke patrzy na nią oczami Georges’a, a ten $z$ kolei patrzy na córkę mądrymi oczami Jean-Louisa Trintignanta (którego wpływ na kształt filmu był znacznie większy niż tylko znakomita kreacja aktorska ${ }^{147}$ ), siedzącego w fotelu, za którym stoi staroświecki, ale markowy sprzęt do odtwarzania muzyki.

Sprzęt stereo, czyli odtwarzacz CD, gramofon i wzmacniacz (z charakterystycznymi wychylającymi się wskazówkami poziomu dynamiki) to w zasadzie jeden z głównych bohaterów filmu: jego zaawansowany wiek (pochodzi mniej więcej z lat 60. ubiegłego stulecia) świadczy, że pamięta młodość pary bohaterów, a więc rozkwit ich miłości (wspominanej przez córkę) i ich kariery jako muzyków (być może nie tylko nauczycieli). Natomiast fakt, że jest

opuchniętą od łez twarzą”. K. Świrek, „Miłość” według najlepszych zasad. O regułach w filmach Michaela Hanekego, „Kultura Liberalna” 2012, nr 46, http://kulturaliberalna.pl/2012/11/13/swirek-milosc-wedlug-najlepszych-zasad-o-regulach-w-filmach-michaela-hanekego-esej/ [dostęp: 30.05.16].

144 „Myślę o momentach, w których czuję największy fałsz - o relacjach z córką, po hanekowsku zimnych, formalnych, nasyconych obcością i utrzymanych w ryzach konwencji przy pozorach wzajemnej otwartości”. M. Sadowska, Martwa natura..., op. cit.

145 „Haneke w ładny sposób daje do zrozumienia już na początku, jak ważna była w ich życiu fizyczna bliskość - odgłosy z sypialni rodziców wspomina w rozmowie z ojcem córka”. K. Frankowska, „Miłość” Hanekego - przerwany chorał Bacha, www.tvp. info/8968512/milosc-hanekego-przerwany-choral-bacha [dostęp: 30.05.16].

146 „Córka - domagająca się od ojca "poważnej rozmowy« o zdrowiu matki, a jednocześnie znacząco milknąca na dźwięk jego ironicznego pytania: »To co, zabierzesz mamę do siebie...?«. Jest miarą wielkiej pokory tego wybitnego filmu, że Haneke nie ulega pokusie krytykowania Evy za jej niezdolność udzielenia prawdziwej pomocy". M. Oleszczyk, Miłość, op. cit.

147 „Tytuł wymyślił Trintignant. Reżyser spełnił prośbę aktora, dla którego - jak deklaruje - wymyślił rolę Georges'a”. K. Frankowska, op. cit. 
wciąż sprawny, pozwala przeplatać za jego pomocą wątki minione i współczesne, przeszłość i teraźniejszość, pamięć i rzeczywistość. Znakomicie wykorzystano to w scenie, kiedy Alexander przysyła swojej nauczycielce płytę z nagraniami. Album rozpoczyna znane już nam Impromptu c-moll Schuberta, jednak po kilku pierwszych fortepianowych frazach Anne mówi do Georges’a stanowczo: „Wyłącz!”.

Jest to być może scena-klucz do całego filmu. Może chodzi o to, że włączając nagranie, Georges zaczął czytać list od Alexandra, w którym ten pisze o swoim współczuciu wobec strasznej choroby Anne - a kobieta nie chciała mieszać tych dwóch porządków, pragnęła cała oddać się muzyce i związanym z nią wspomnieniom. Może chodzi o to, że dźwięki dobrze znanej kompozycji (pewnie to nauczycielka jako pierwsza prezentowała ją swemu wychowankowi) uświadomiły Anne, że w obecnym stanie (wylew i związany z nim paraliż prawej strony ciała) nie jest już tak naprawdę tą samą osobą, która kiedyś grała ją na fortepianie. A może w ogóle chodzi o dotkliwość i przenikliwość muzyki, która dotyka nas tak mocno, jak nie są w stanie dotknąć ani słowa, ani fizyczne cierpienie. Tak czy owak, ważniejsze dla filmu od brzmiącej jedynie przez moment muzyki jest jej nagłe zastopowanie i następujące po nim ujęcie (modelowy przykład efektu, który Siegfried Kracauer określa jako „cisza naładowana napięciem” ${ }^{148}$ ). Ujęcie oczywiście długie i statyczne - pokazuje, jak Anne i Georges siedzą nieruchomo przy wyłączonym odtwarzaczu CD. Bardzo starzy oboje.

Milknący nagle utwór Schuberta pojawia się mniej więcej w połowie filmu (co również może sugerować, że jest jego osią), ale powrót muzyki jako fizycznie obecnego muzycznego narratora odbywa się kilka minut wcześniej, przy okazji wizyty, jaką Anne i Georges’owi składa Alexander. Artysta, mniej więcej rówieśnik młodego bohatera z Pianistki, podobnie jak Walter uwielbia muzykę Franza Schuberta („Moje życie kręci się obecnie wokół Schuberta”), ale choć mówi o niej z pewną egzaltacją, to ma jednak więcej pokory („Miałbym ochotę zagrać wszystkie sonaty. Ale ostatnie powinny chyba jeszcze poczekać”). Tak jak większość późnych dzieł wielkich mistrzów (np. Die Kunst der Fuge Bacha czy ostatnie Kwartety smyczkowe Beethovena), także schyłkowe sonaty Schuberta cieszą się wyjątkową estymą

148 „Efekt potęguje się, gdy muzyka nagle urywa się w momencie największego napięcia, pozostawiając nas sam na sam z obrazem”. S. Kracauer, op. cit. 
tyleż jako nadzwyczaj dojrzałe dzieła muzyczne, ile jako filozoficzne medytacje nad istotą muzyki i ludzkiego życia - a zatem wręcz nie wypada, by brał się za nie młody, dopiero debiutujący wykonawca. Jakby na potwierdzenie tej zasady, Anne prosi Alexandra o zagranie utworu, który wykonywał na jej lekcji, kiedy był dwunastoletnim chłopcem, czyli Bagateli d-moll Ludwiga van Beethovena.

Ta stosunkowo prosta, pogodna kompozycja pełni w filmowej narracji dwie funkcje. Po pierwsze, pozwala Anne odbyć podróż w czasie do momentu, gdy była jeszcze w pełni sił witalnych i artystycznych (Haneke pozostaje wierny sobie: żadnego sentymentalizmu; jest zwięzły i lakoniczny, pozostawiając widza z oceną, kiedy i jakie emocje odzywają się w bohaterach filmu ${ }^{149}$ ), po drugie zaś, utwór swoją lekkością i bezpretensjonalnością zdejmuje z całej sceny ciężar, który niewątpliwie podkreśliłby jakiś „późniejszy” (filozoficznie medytujący nad istnieniem) utwór Beethovena lub Schuberta. Tymczasem Haneke rozgrywa dramat Anne inaczej: dźwięk fortepianu w Beethovenowskiej Bagateli płynnie przechodzi w szum elektrycznego wózka inwalidzkiego, którym kobieta uczy się jeździć w następnej scenie, a montaż ujęć jest celowo ułamek sekundy spóźniony względem muzyki. Po chwili ten sam zabieg - przeplatania się dźwięków z porządku sztuki i porządku życia, płynnego przechodzenia tego, co artystycznie wzniosłe, w to, co trywialnie przyziemne - zostaje powtórzony, tyle że w odwrotną stronę, i szum wózka na korytarzu mieszkania przechodzi w dźwięk fortepianu, na którym gra Georges, siedząc samotnie w salonie. Jednak odgrywane frazy są już zupełnie inne: zamiast pełnej wigoru Bagateli słyszymy fortepianową przeróbkę pełnego powagi i zadumy preludium chorałowego Jana Sebastiana Bacha Ich ruf zu Dir, Herr Jesus Christ.

Tytuł „Wołam do Ciebie, Panie Jezu Chryste” wiele mówi o nastroju i przesłaniu kompozycji, natomiast fakt, że gra ją Georges - niezdradzający przez cały film żadnych przejawów wiary religijnej - świadczy zarówno o głębokości zakorzenienia utworu Bacha w kulturze, jak i o nader nieoczywistej pozycji, jaką film Hanekego zajmuje względem religii chrześcijańskiej

149 Podejście bohaterki do przeszłości - a przy okazji „antymelancholijne” w swej lakoniczności podejście reżysera - świetnie ukazuje krótki (trzywyrazowy) dialog starego i, jak się okazuje, dobrego małżeństwa nad albumem ze zdjęciami: „Anne: Piękne. Georges: Co? Anne: Życie”. 
i związanymi z nią ideami. Aby pojąć wieloznaczność tej sceny, musimy uzbroić się w wiedzę o zakończeniu filmu, w którym Georges, w obliczu zupełnej zapaści Anne (przykuta do łóżka kobieta traci kontakt ze światem i przestaje przyjmować pokarmy), dusi żonę poduszką. Po zabójstwie Georges urządza dla Anne symboliczną i przejmującą w swojej intymności ceremonię pogrzebową, po czym kładzie się na łóżku, by popełnić rozłożone w czasie samobójstwo przez zagłodzenie się. Obserwując te działania (z wyjątkiem sceny z poduszką pełne raczej spokojnej metodyczności niż wyrazistego dramatyzmu), warto pamiętać o jednej ze scen, rozgrywającej się zaraz po stwierdzeniu choroby u Anne, kiedy prosi ona męża, aby w razie pogorszenia się jej stanu zdrowia nie opuszczał jej (czyli np. nie oddawał do hospicjum), ponieważ z tym kontekście uczynki Georges’a zyskują wymiar dotrzymania obietnicy. Nie tylko tej z początku filmu, ale i tej dużo wcześniejszej, z czasów sprzed filmowych wydarzeń - o wierności i nieopuszczaniu aż do śmierci.

Wróćmy teraz do preludium chorałowego Bacha i wątku religijnego w filmie. Jeżeli odrzucimy interpretacje skrajne - zarówno zarzuty o radykalną antyreligijność (głównie dość powierzchowne oskarżenia ${ }^{150}$, w których często pada nacechowane ideologicznie słowo „eutanazja”), jak i nazbyt skwapliwe konotacje z symboliką chrześcijańską (jak ta łącząca gołębia i „religijną busolę”, wspomniana przeze mnie we wstępie tej pracy), pozostaje do rozważenia całkiem spory obszar „pomiędzy”. Najbardziej intrygujące $\mathrm{w}$ nim wydają się sugerowane ślady mocnych i tajemnych więzi religii ze sztuką (która niejako wzięła na siebie dawne obowiązki teologii i filozofii religijnej ${ }^{151}$ ), a także spostrzeżenia na temat miłości, w których aspekt

150 „W zakresie formy i środków realizacji film Michaela Haneke Miłość jest bardzo prosty. W sferze emocjonalnej - to tortura. W sferze przesłania - prawdziwa bomba, którą wypada nazwać antychrześcijańską do szpiku kości”. P. Gociek, Chory film o miłości, http://wpolityce.pl/kultura/246542-premiera-kinowa-michaela-haneke-chory-film-o-milosci-nasza-recenzja [dostęp: 30.05.16].

151 „Nie zamierzam dowodzić, że Haneke podejmuje w swoim filmie treści teologiczne - nawet jeśli niektórzy je w nim odnajdą, to artysta zapewne ich tam nie umieścił. Uprawia on jednak sztukę na tak wysokim poziomie, tak bezkompromisowo poszukuje prawdy o człowieku, że najistotniejsze kwestie natury filozoficznej czy teologicznej pojawiają się w jego dziełach w sposób samoistny. Nie stanowią 
chrześcijański pojawia się od zupełnie niedoktrynalnej strony ${ }^{152}$. Nie w tym rzecz, czy taka była pierwotna intencja Michaela Hanekego (który pytania dziennikarzy o metafizyczne aspekty w swoich filmach raczej zbywa ${ }^{153}$, choć od wysokich aspiracji muzyki bynajmniej się nie odżegnuje ${ }^{154}$ ), ale w tym, że użycie preludium chorałowego Bacha (tak jak wcześniej Podróży zimowej Schuberta) przenosi film w tak szeroką sferę kontekstów, na szachownicę $\mathrm{z}$ tak wieloma figurami kulturowych tropów i toposów, że austriacki reżyser, przy całej swojej erudycji, nie byłby w stanie wszystkich przewidzieć i świadomie wciągnąć w filmową grę.

Co najmniej równie ważny, jak samo użycie w filmie Ich ruf $z u$ Dir, Herr Jesus Christ, jest sposób, w jaki utwór wpływa na rozwój wydarzeń. Fortepianowa transkrypcja utworu Bacha (skomponowanego na organy) dokonana przez Ferruccio Busoniego bywa chętnie wykorzystywana w muzycznej edukacji, więc Georges mógł ją kiedyś grywać niejako zawodowo - tym razem jednak okoliczności są zgoła inne. Może mieć to wpływ na grę, która - jakby zdziwiona samą sobą, czyli swoim nieoczekiwanym rysem medytacyjnym (bo nazwać go "modlitewnym”, tego byłoby już dla Hanekego zbyt wiele) - nagle się urywa. Nie wiemy, czy Georges jest zawstydzony utworem,

one jednak wykładni konkretnej doktryny religijnej czy kierunku filozofii”. Miłość, czyli rana, [Katarzyna Jabłońska w rozmowie z ks. Andrzej Lutrem], „Więź” 2012, nr 10 .

152 „Jego Miłość to śmiała propozycja wejścia w samo centrum miłości, czyli... w ranę. Bo »Prawdziwa miłość - jak mówi Wiesław Myśliwski w Traktacie o łuskaniu fasoli - jest raną. I tylko tak ją można odnaleźć w sobie, gdy czyjś ból boli człowieka jako jego ból«. Może więc uprawniona jest nadzieja, że jeśli czyjś ból boli mnie tak jak tego, który cierpi, to staje się rodzajem mostu, prowadzącego nas do siebie nawzajem?”. Ibidem.

153 „Gołąb jest stamtąd, pojawia się niczym nieobecny dotąd u tego reżysera mistyczny ornament, znak do zinterpretowania, niepokojący dla jednych, irytujący dla drugich. Pytany o niego, sam Haneke odpowiada po prostu: »W Paryżu jest mnóstwo gołębi«". M. Sadowska, Martwa natura z gołębiem, op. cit.

154 „Wielka muzyka wynosi współczucie ponad konkretne przypadki. Podró $z$ zimowa wynosi nawet ludzką marność na poziom wyjątkowego opisu. Wszelkie fundamentalne dzieła, szczególnie te, które koncentrują się na ciemnych stronach istnienia, wbrew całej rozpaczy, wynoszą nieszczęsną treść na wyżyny swej formy”. The World That Is Known, op. cit. 
po jaki sięgnął (intensywnie nacechowanym religijnie), czy też nagle zrozpaczony - bo oto ujrzał w muzycznym lustrze sprzed wieków dwie twarze: swoją i śmiertelnie chorej Anne. Wiemy tylko tyle, że utwór milknie. Znowu zapada „cisza naładowana napięciem”, ale tym razem kamera - inaczej niż w modelowym przykładzie Siegfrieda Kracauera - jest gdzie indziej: w sypialni żony, proszącej, aby grał dalej. Jej wołanie pozostaje jednak bez odpowiedzi.

Scena jest ważna dla filmu na dwóch poziomach. Tym „metafizycznym”, o jakim wspomniałem w poprzednich akapitach, i tym - dla kontrastu całkiem przyziemnym, dotyczącym banalnej codzienności bohaterów. Otóż wydaje się, że do momentu choroby to Anna była w tym małżeństwie związku na pewno wykraczającym daleko poza domową krzątaninę i społeczne konwenanse ${ }^{155}$ - stroną aktywniejszą i bardziej dominującą. Widać to $\mathrm{w}$ drobiazgach, tonie głosu czy gestach, ale niektóre $\mathrm{z}$ tych drobiazgów łączą się z najważniejszymi motywami filmu - na przykład z poleceniem natychmiastowego wyłączenia odtwarzacza z płytą Alexandra albo napomnieniem, by Georges wziął płaszcz, w finałowej, metaforycznej scenie filmu (kiedy obydwoje już nie żyją, co przejawia się tym, że po prostu wychodzą z mieszkania, ale przecież wychodzą tacy, jacy byli wcześniej, przed nadejściem choroby). Od pewnego momentu jednak, po wylewie Anne, to jej mąż przejmuje prawo do mentalnej dominacji i stopniowo zaczyna przejawiać inicjatywę nie tylko w sprawach bezpośrednio związanych $\mathrm{z}$ opieką. Urwany - mimo protestów żony - chorał Bacha może być zatem wyrazem emancypacji mężczyzny, wcześniej trochę „pantoflarza”, który coraz wyraźniej zdaje sobie sprawę nie tylko z powagi obecnej sytuacji (bierze więc na siebie coraz więcej odpowiedzialności - aż do ostatecznej granicy pod koniec filmu), ale także, patrząc wstecz, z charakteru całego trwającego pięć dekad związku.

Przemianę Georges'a może sugerować kolejna z najważniejszych scen filmu. Oto mężczyzna słucha, jak siedząca naprzeciw przy fortepianie Anne gra Impromptu Ges-dur Schuberta. Utwór jest pełen radosnej energii, a zatem mocno kontrastuje $\mathrm{z}$ wydarzeniami, które oglądaliśmy ledwie

155 „Są jak jeden organizm, co widać, gdy tylko pojawiają się w kadrze. Po raz pierwszy oglądamy ich w dalekim planie, w filharmonii. Siedzą w tłumie innych widzów, a jednak się wyróżniają. Nie ma wątpliwości, że są razem, nawet wtedy, gdy na siebie nie patrzą". K. Frankowska, op. cit. 
chwilę wcześniej. Lecz raptem Georges odwraca się, wyłącza stający za fotelem odtwarzacz - i wtedy muzyka milknie, a żona znika. Pozostajemy na dłuższą chwilę sam na sam $\mathrm{z}$ mężczyzną wpatrzonym w samotnie stojący fortepian (przejmująca twarz Jeana-Louisa Trintignanta zdaje się mówić: żadnych sentymentów). Scena jest wyrazista i efektowna, ale choć można ją porównać do sceny z jazgotem Johna Zorna zagłuszającym szacowną klasykę w Funny Games albo z Andantinem Schuberta, przeniesionym przez bohaterkę Pianistki z wysokich progów konserwatorium w wulgarne realia sex shopu, to została nakręcona $\mathrm{z}$ tak sugestywnym umiarem, przejmującą lakonicznością środków wyrazu, że pozostajemy z wrażeniem, iż nie tylko Georges się zmienił. Zmienił się także sam Haneke ${ }^{156}$.

Oprócz podstawowych znaczeń (świetnie uchwycone działanie mechanizmów pamięci czy też wyraz „antymelancholijnego” przesłania filmu Hanekego), nagle milknące Impromptu Schuberta można odebrać jako dowód, że to Georges ma teraz inicjatywę, czy nawet władzę w tym domu ${ }^{157}$. I zbiera się na odwagę, by przerwać żonie grę. Jest za późno, by zrobić to realnie, w rzeczywistym świecie - gdzie Anne już nie rusza się z łóżka, pogrążona w majaczeniach - więc Georges wyobraża ją sobie na tle grającej płyty. Warto w tym kontekście przypomnieć, że w tym samym czasie co Miłość trafił na ekrany film Wulkan islandzkiego reżysera Rúnara Rúnarssona,

156 „Swoistą cechą poprzednich filmów Hanekego była ich dosadność, która przeradzała się w pewnego rodzaju atrakcyjność. [...] W Miłości Haneke tylko raz pozwala sobie na scenę, która miałaby wywołać w widzu z góry określoną reakcję. Pod koniec filmu obserwujemy, jak Anne gra na fortepianie. Kilka sekund później kamera pokazuje siedzącego w tym samym pokoju Georges'a, obserwującego żonę. Po chwili mężczyzna wyłącza stojący za nim odtwarzacz, a muzyka momentalnie ucicha. Tak prosta, kumulująca emocje, ale - co świadczy o niezwykłej sprawności austriackiego reżysera - pozbawiona sentymentalizmu scena robi o wiele większe wrażenie niż tysiąc obrazów powolnej agonii, za pomocą których można by tę historię przedstawić”. G. Fortuna, op. cit.

157 „Ze wszystkich relacji miłosnych w jego filmach ta wydaje się najbardziej »ludzka«, pozbawiona egoizmu, oparta na wzajemnym oddaniu. Ale i tu wkrada się coś mrocznego. Czy w poświęceniu Georges’a nie ma czegoś ukrycie sadystycznego? Jakiejś okrutnej nadwyżki? Odmawiając oddania Anny do hospicjum [...], czyni ją całkowicie zależną od swojej pomocy i opieki. Anna jest w jego władzy”. J. Majmurek, op. cit. 
opowiadający zaskakująco podobną historię o samotnym mężczyźnie, który opiekuje się chorą żoną po wylewie (podobieństwo obu wątków jest tak duże, że tylko fakt, iż filmy były kręcone równolegle, zdejmuje z Hanekego cień podejrzenia o plagiat). W Wulkanie jednak to właśnie kwestia władzy, jaką uzyskuje nad żoną stary rybak Hannes, wysuwa się zdecydowanie na pierwszy plan i prowadzi do dramatycznych konsekwencji ${ }^{158}$.

Wracając do filmu Hanekego, trudno wyrokować, czy wyłączenie przez Georges’a odtwarzacza to bardziej wyraz przejęcia władzy (nie tyle może nad Anne, co nad bezlitosną pamięcią), czy skromniej - deklaracja niepodległości (znów: nie wobec drugiego człowieka, ale wobec własnej melancholii). Natomiast wolno sądzić, że ten stanowczy gest mieści się nie tylko wewnątrz rzeczywistości filmu - jest także gestem wobec widza, który dopóki brzmiała muzyka, nie zdawał sobie sprawy, że widzi przy fortepianie tylko wyobrażoną Annę. Nagła cisza jest jak gwałtowne rozwianie złudzenia. Demaskowanie fantazmatów i złudzeń zarówno filmowych bohaterów, jak i kinowych widzów zawsze było spécialité de la maison Hanekego, rzadko jednak robił to w sposób tak artystycznie wyrafinowany ${ }^{159}$.

Zatrzymajmy się jeszcze przez moment na wyraźnie widocznym w tej scenie, wspomnianym już przeze mnie „antymelancholijnym” charakterze filmu Hanekego. $Z$ całą pewnością reżyser nie podchodzi cynicznie do duchowej siły wspomnień czy narracyjnych zdolności ludzkiej pamięci o czym przekonuje chociażby scena, kiedy Georges mówi Anne o filmie, który jako dziecko oglądał, a jakiś czas potem opowiadał, wzruszony wtedy filmową historią jeszcze bardziej („Kiedy opowiadałem, łzy wracały, silniejsze niż podczas seansu"). Podejście Hanekego - wymierzone

158 „Hannesowi zostają tylko dwie wierne towarzyszki - żona i rybacka łajba. Kiedy ta druga niemal idzie na dno, mężczyzna chce poświęcić czas i pieniądze na jej naprawę. Podobnego "zabiegu« nie jest w stanie przeprowadzić na żonie, która rażona wylewem krwi do mózgu, nagle przewraca się na podłogę. Odtąd będzie wegetować pod opieką męża, który pod pretekstem zadośćuczynienia za dotychczasową nieczułość nie odda jej do domu opieki. Na ile jednak Hannes naprawdę się zmienił?". www.nowehoryzonty.pl/film.do?id=5286\&ind=page\%3d0\%26typ\%3ddz\%26edycjaFest\%3d11\%26czas\%3d15\%253a45\%26dzien\%3d26 [dostęp: 30.05.16].

159 „Nie wiem, czy Miłość jest najlepszym filmem Hanekego, na pewno jest jednak najbardziej subtelnym z nich”. G. Fortuna, op. cit. 
choćby przeciwko światopoglądowi Larsa von Triera, wyrażonemu w filmie Melacholia - dobrze oddaje scena, kiedy Georges po powrocie z pogrzebu przyjaciela opowiada anegdotyczną historię o puszczonym podczas ceremonii Yesterday Beatlesów, na które żałobnicy zareagowali „atakami śmiechu". Nie w tym rzecz, czy uczestnicy pogrzebu albo Anne z Georges'em lubią tę słynną piosenkę (i jaki mają ci akademiccy melomani stosunek do muzyki popularnej). Chodzi o odcięcie się od wszelkiego sentymentalizmu czy rozczulania się nad przemijaniem ${ }^{160}$, na które - w innym momencie filmu - Georges reaguje tak stanowczo, że nawet Anne oraz pełne energii Schubertowskie Impromtu muszą zniknąć z pola widzenia i słyszenia.

Takie odczytanie tej sceny to oczywiście tylko kolejna $\mathrm{z}$ wielu możliwych wersji. Interpretacyjne furtki, które pozostawia muzyczna narracja w Miłości, zawierają się w niedomówieniach i sugestiach. Dzieje się tak dlatego, że film - inaczej niż choćby Pianistka - opiera się na wygrywaniu kontrastów między muzyką a milczeniem, na dialektyce dźwięku i ciszy (według Carla Dahlhausa, dla muzyki niezwykle istotnej ${ }^{161}$ ), którą Haneke zręcznie umieścił w pospolitych realiach ${ }^{162}$. Pozwala to widzowi (bo sama historia jest zaiste „prosta”) dociekać kolejnych znaczeń zarówno „wewnątrz”

160 „Kiedy Anna jest już po operacji, Georges jedzie na pogrzeb, na którym, jak potem opowiada, ktoś puszcza $z$ taśmy piosenkę The Beatles Yesterday. Owszem, to żenada. Która ma potwierdzić fakt, że sam film z pewnością nie jest nostalgiczny. Nie pojawia się najmniejsza sugestia, jakoby wczoraj w życiu Anny i Georges'a, podobnie jak w piosence Beatlesów, wszystkie kłopoty wydawały się takie odległe". R. Gilbey, op. cit.

${ }^{161}$ „Myślą przewodnią wszystkich jego rozważań było głębokie przekonanie, iż konkretny problem widzimy naprawdę dopiero wówczas, gdy ujęty jest w przeciwieństwach”. A. Jarzębska, op. cit.

162 „Taka jest cała muzyka w filmie, ta wykonywana przez bohaterów jest raptownie przerywana, zaś ta, którą wykonuje ktoś inny, jest wyciszana przez wyłączenie odtwarzacza. Muzyka milknie, w zgodzie z intencjami bohaterów, a nie w zgodzie z logiką filmowej narracji. Takie realizacyjne wyrachowanie, jego naga brutalność, jest zgodna z emocjonalnym nastrojem filmu. Rozpoznajemy tu typową dla Hanekego przyjemność w zawodzeniu oczekiwań widza poprzez bełtanie klarownej narracji i diegezy, ale także zgoła metafizyczną inklinację, by sens ukazywał się raczej w wyniku swoistej iluminacji niż konkretnie, czarno na białym". http:// framescourer.blogspot.com/2012/11/music-in-amour-2012.html [dostęp: 30.05.16]. 
opowiadanej historii (w wydarzeniach i zachowaniach bohaterów), jak i „na zewnątrz" - w odnajdywanych tropach kulturowych.

Jeżeli chodzi o tę drugą, metafilmową sferę, to nader ciekawy jest fakt, że po to samo Bachowskie preludium chorałowe Ich ruf zu Dir, Herr Jesus Christ sięgnął Andriej Tarkowski w filmie Solaris ${ }^{163}$, nakręconym na motywach powieści Stanisława Lema. Pierwsze skojarzenie to myśl o hołdzie złożonym rosyjskiemu reżyserowi, którego podejście do montażu muzyki w filmie (jej „naturalna” obecność - jako dźwięku ze świata, treściowej esencji wydarzeń, a nie ich formalnej ramy) $\mathrm{z}$ pewnością wpłynęło na Hanekego.

Kiedy jednak przyjrzymy się tym filmom uważniej, to okazuje się, że w obydwu kluczowe są motywy tracenia ukochanej osoby (w Solaris już się ono dokonało - astronauta Kelvin trafia na obcą planetę po śmierci swej żony, Harey, natomiast w Miłości dzieje się to na naszych oczach) oraz jej nadnaturalnego - powrotu. U Tarkowskiego sprawcą wskrzeszenia Harey, a właściwie jej cielesnego hologramu, jest Ocean, zajmujący całą planetę Solaris i przejawiający zgoła boskie kompetencje. U Hanekego „wskrzeszenie" Anne dokonuje się za sprawą muzyki Schuberta - której podprogowe fale mają dostęp do pamięci i wyobraźni Georges’a. Co ciekawe, obaj - Kelvin i Georges - nie godzą się na takie rozwiązanie: niszczą to, co wydaje się wybawieniem od śmierci, czyli podsunięte im fantazmaty Harey i Anne. Obaj wiedzą, że ich wyrwane z objęć śmierci ukochane są atrapami, wytworami tęsknot i wspomnień, a nie realnymi kobietami. Śmierć potwierdziła prawdę ich życia - nieodwracalnie. I w tym miejscu pojawia się Bach z całym chrześcijańskim zapleczem i jego centralną postacią - Jezusem Chrystusem, który umarł, aby żyć. Kelvin w Solaris mówi: „Kochamy tylko to, co możemy utracić”; Georges w Miłości wyłącza muzykę, aby nieprawdziwa Anne znikła.

Preludium chorałowe Bacha u Tarkowskiego pojawia się w różnych miejscach filmu, nawet jako tło dla napisów, i jest grane w pierwotnej aranżacji na organy, a więc brzmi dostojnie i wzniośle, wypełnia przestrzeń szczelnie. Wrażenie szczelności wzmaga sugestywna aranżacja dokonana przez Edwarda Artemiewa, w której tło dla organów stanowią elektroniczne efekty

163 „Oto więc znaczenie Ich ruf zu dir, Herr Jesu Christ (BWV 639) J.S. Bacha granego przez Georges’a ze złamanym przez ból sercem: to muzyka religijna, której trzeba słuchać koniecznie w kontekście medytacji Tarkowskiego nad miłością i utratą w Solaris (1972)". Ibidem. 
dźwiękowe. Ich specyficzne zagęszczenie ewokuje atmosferę metafizycznej tajemnicy (dodatkowo wzmocnione zdjęciami, szczególnie w scenach, kiedy główny bohater powraca do domu nad stawem, a swojskie ziemskie krajobrazy zdają się zrzucać maskę realności i wkraczać w sferę symboliczną), co pomaga dostrzec $\mathrm{w}$ dziele Tarkowskiego tropy teologiczne albo wręcz gnostyckie. Owszem, można doszukiwać się takich motywów także w powieści Lema ${ }^{164}$, ale styl pisarza, mimo konwencji science-fiction, jest w Solaris bliski raczej stylowi powieści psychologicznej. Natomiast użycie chorału Bacha przez Tarkowskiego - w dodatku chorału spreparowanego przez Artemiewa tak, by pobrzmiewał "mistycznie” - jest nie tylko radykalnym wyłamaniem się z Lemowskiej konwencji (lista zarzutów polskiego pisarza wobec rosyjskiego reżysera była zresztą długa), ale także porzuceniem skromnego realizmu psychologicznego - nawet wobec „cudów” dokonywanych przez solaryjski ocean - na rzecz wzniosłego uduchowienia.

$\mathrm{Na}$ tym tle fortepianowa przeróbka Bachowskiego chorału w filmie Hanekego okazuje się tym bardziej dyskretna, zaś fakt, że dźwięki nie płyną zza kadru, tylko wydostają się - w efemerycznej, kruchej postaci - spod palców bohatera, świadczy tyleż o zupełnie innej pozycji filmu wobec religijno-filozoficznej tradycji, ile o innym języku, który austriacki reżyser wybiera.

Haneke niby składa Tarkowskiemu hołd, ale jednak go kwestionuje. Niby nie dociera w Miłości do takiej sublimacji duchowych przeżyć jak rosyjski reżyser, ale w istocie dociera być może jeszcze dalej - tam, gdzie arbitralny ton prawd wiary czy epokowych dzieł sztuki milknie wobec pojedynczej i skromnej prawdy ludzkiej. Preludium chorałowe Bacha opowiada nam w Miłości to samo, co w Solaris, a jednocześnie - za sprawą znaczących korekt reżyserskich - odzywa się z innego źródła, innym językiem.

164 „Jak zatem jawi się im solariański Ocean na nowo? Jako zalążek Boga ułomnego lub kalekiego, którego możliwości, zdolności przerastają jego świadomość i rozumność. Albo jako Bóg o wielkim potencjale, lecz psychice małego dziecka; dziecka, które ma wszelkie dane ku temu, by dorosnąć. Widać zatem, że nowe rozumienie Oceanu wydostało się już poza schemat ściśle naukowy. Jest on pojmowany jako istota z dwóch paradygmatów: przyrodniczego i teologicznego zarazem”. M. Dobkowski, Solaris. Gnoza i optymizm technologiczny, www.gnosis.art.pl/e_gnosis/ksiazki_stare_i_nowe/dobkowski_solaris.htm [dostęp: 28.03.16] 
Tym językiem mówi też muzyka w scenie, w której osiąga przejmująco ludzki wymiar: kiedy Georges śpiewa z żoną piosenkę Sur le Pont d’Avignon. Głos tracącej zmysły i dotkniętej afazją kobiety ledwie potrafi uchwycić melodię piosenki, łamiąc się w niemal dosłownym sensie, ale na twarzy Anne widzimy, po raz ostatni, błysk radości. To jej ostatni kontakt z rzeczywistością: melodia dziecięcej piosenki o tańczeniu na moście, który - całkiem jak ludzkie życie - urywa się nagle na środku rzeki ${ }^{165}$.

Do końca filmu zostaje - po scenie ze wspólnym śpiewaniem - jeszcze pół godziny. Ale nie usłyszymy już ani Schuberta, ani Beethovena. Zamilknie fortepian w salonie i staroświecki sprzęt $h i-f i$ za fotelem. Michael Haneke mimowolnie postępuje dokładnie według credo Krzysztofa Komedy, zgodnie z którym muzyki w filmie powinno być raczej za mało niż za dużo ${ }^{166}$. Dziecięca piosenka to ostatnia rzecz, jaką muzyka w Miłości ma do powiedzenia.

\section{ZAKOŃCZENIE: O WZAJEMNOŚCI}

„kiedy nas wnętrze otacza jak najdoskonalsza dal"

Rainer Maria Rilke, Do muzyki (tłum. A. Lam)

Jak wynika z mojej analizy, muzykę w filmach Michaela Hanekego można rozpatrywać w trzech podstawowych kontekstach. Są to:

1) Związki muzyki w danym filmie z przedstawionymi w nim wydarzeniami i wyrażonymi ideami.

2) Związki między muzyką z różnych filmów austriackiego reżysera.

3) Związki między muzyką u Hanekego a muzyką w filmach innych reżyserów.

165 Pont Saint-Bénézet (pol. Most św. Benedykta), znany także jako Pont d'Avignon - średniowieczny most nad rzeką Rodan w Awinionie (Prowansja, Francja), zachowany częściowo. Według jednej z tradycji most nie został ukończony i nigdy nie sięgnął do drugiego brzegu. http://pl.wikipedia.org/wiki/Pont_Saint-Benezet [dostęp: 28.03.15].

166 K. Komeda, Ankieta: Rola muzyki w dziele filmowym, „Kwartalnik Filmowy” 1961, nr 2. 
W każdym z omówionych przeze mnie filmów te trzy relacje zachodzą $\mathrm{w}$ różnym stopniu, zawsze jednak poszerzając ramy interpretacyjne oraz inspirując widza do aktywnego, zaangażowanego intelektualnie odbioru dzieła. Obserwując zmiany w użyciu utworów między poszczególnymi filmami, można wnioskować, że i sam reżyser był przez muzykę (która towarzyszyła mu od dzieciństwa i była pierwszym wyborem edukacyjnym ${ }^{167}$ ) inspirowany do zmian, jakie na przestrzeni kariery zachodziły w jego stylu czy podejściu do materii filmowej, w tym także do kompozycji, po jakie sięgał ${ }^{168}$. Zmiany te są widoczne na wszystkich trzech poziomach obecności muzyki w jego filmach. Zreasumujmy je pokrótce.

Jeżeli chodzi o związki muzyki z filmem, w którym ją słyszymy, to w Funny Games muzyka została pomyślana jako swego rodzaju uwertura (zapowiadająca przebieg wydarzeń, zwięźle portretująca bohaterów oraz sugerująca istotne założenia wstępne). W Pianistce towarzyszy, blisko i wytrwale, rozwojowi wydarzeń (dla których bywa albo dopowiadającym komentarzem, albo kontrapunktem pozwalającym widzowi na inne spojrzenie) oraz czujnie asystuje bohaterom (pogłębiając wgląd w ich motywacje i działania). Natomiast w Miłości pozostaje stale obecna w filmie, tyle że jest to obecność szczególna: mniej „ciałem”, czyli słyszanym dźwiękiem (który nader często milknie), a bardziej „duchem”, czyli ciszą po urwanym dźwięku (która okazuje się milczeniem nader znaczącym).

Jeżeli chodzi o relacje między tymi trzema filmami, to z perspektywy muzyki wyraźnie daje się zauważyć, jak Haneke zmienia podejście do tworzonego przez siebie filmu (na poziomie opowiadanej historii, a także wglądu w psychikę bohaterów), rezygnując z nadmiaru arbitralności i reżyserskiej

167 „Zawsze chciałem być muzykiem, najlepiej kompozytorem albo dyrygentem. Nie starczyło mi talentu". Wrzątek podany na zimno, op. cit.

168 „Widać, że od jakiegoś czasu [Haneke - przyp. M.W.] szuka nowych środków wyrazu, boi się, że jego styl zakrzepnie w manierę. Było to już bardzo widoczne w Białej wstążce. Miłość to najbardziej »klasyczny« film Hanekego. Nie ma tu znanych z poprzednich obrazów technik »strategicznej dezorientacji widza«. Od początku kamera jasno zakreśla przestrzeń akcji (mieszczański apartament) i precyzyjnie opisuje postacie. Dominują statyczne kadry kręcone nieruchomą kamerą, montaż na zasadzie ujęcie-przeciwujęcie, środki pozwalające »wybrzmieć" aktorom, odtwarzanym przez nie postaciom i ich emocjom”. J. Majmurek, op. cit. 
władzy. O ile muzyka na początku Funny Games - nagłe zburzenie przez Johna Zorna bezpieczeństwa zbudowanego przez Haendla i Mascagniego skutkuje gwałtownym przebiegiem późniejszej akcji i niejako „zaostrza” obyczaje (bohaterów-morderców oraz reżysera znęcającego się nad widzem), to muzyka w Pianistce - choćby Schubertowskie Andantino, towarzyszące bohaterce w kabinie porno - przebieg akcji i obyczaje łagodzi. Przy okazji znika także dawne - obecne $\mathrm{w}$ jeszcze wcześniejszych filmach reżysera wyniosłe spojrzenie prokuratora (znajdującego winę) czy chirurga (znajdującego zwyrodnienie) ${ }^{169}$, ponieważ przestaje być możliwe w tak szerokim polu skojarzeń i emocji, jak to, które otwiera muzyka Schuberta czy Chopina. W muzyce zapisana została „romantyczna” matryca zachowań Eriki Kohut, jej skłócona $\mathrm{z}$ życiem osobowość - i w tym sensie muzyka jest jednym z głównych bohaterów Pianistki $i^{170}$.

Jeszcze wyraźniej uniezależnienie się muzyki od reżysera-demiurga widać w Miłości, gdzie utwory klasycznych kompozytorów - jakby w kontraście czy wręcz w polemice z Pianistka - pojawiają się znacznie rzadziej. Zarówno ulotna obecność, jak i wieloznaczne milczenie muzyki w tym filmie sugeruje przeniesienie opowiadanej historii ponad wymiar służebny wobec jakiegokolwiek z góry przyjętego pomysłu czy przesłania ${ }^{171}$. Haneke tak samo nie próbował „reżyserować" naturalnych zmarszczek starości na twarzy czy przygarbionych sylwetek Emmanuelle Rivy i Jean-Louisa Trintignanta, jak i obecności chorałowego preludium Bacha. W fizycznej

169 „Haneke zawsze sytuuje się ponad własnymi postaciami, wygrywając ich dewiacje, lęki bądź okrucieństwa nie po to, by swych bohaterów lepiej poznać, ale po to, by udowodnić widzowi, że już dawno przejrzał ich wszystkich na wylot i że nie pomylił się w swojej ponurej diagnozie”. M. Oleszczyk, Biała wstążka, „Dwutygodnik” 2009, nr 11, www.dwutygodnik.com/artykul/595-biala-wstazka -rez-michael-haneke.html [dostęp: 28.03.15].

${ }^{170}$ „W filmie Hanekego muzyka nie jest wyłącznie ilustracją fabuły, jest rzeczywistym podmiotem historii”. G. Arata, op. cit.

171 „Haneke jest mistrzem podskórnej sugestii, która czasami (jak w Białej wstążce) puchnie w wątpliwą historiozofię, ale w Miłości służy trzeźwemu zasugerowaniu, iż oglądamy parę z własną przeszłością, z pewnym zestawem wspomnień, ran i prowizorycznie zażegnanych pretensji, bez których nie ma mowy o żadnym współistnieniu”. M. Oleszczyk, Miłość, op. cit. 
(czyli słyszalnej) przestrzeni filmu pojawia się ono ledwie na kilkanaście sekund, ale na głębszym poziomie „brzmi” dalej. Zakończenie Miłości, podobnie jak finałowa scena Pianistki, obywa się w ogóle bez tła muzycznego, jednak zbieranie się dwojga - już nieżyjących - bohaterów do wyjścia z mieszkania, banalne zmywanie ostatnich naczyń, by zostawić porządek, czy sięganie po płaszcze z wieszaka niesie w sobie szczególne „znaczeniowe echo" muzyki, którą słyszeliśmy wcześniej.

To, co „słyszeliśmy wcześniej”, okazuje się w twórczości Hanekego ważne nie tylko w obrębie konkretnego filmu czy poprzednich obrazów reżysera, ale też w kontekście klasycznych dzieł kina światowego. Preludium chorałowe Bacha w Miłości to rodzaj „korespondencji pośmiertnej” Michaela Hanekego z Andriejem Tarkowskim, który użył tego utworu w Solaris. Solaris to pod wieloma względami film chybiony technicznie i adaptacyjnie $^{172}$, co nie zmienia faktu, że znając konteksty użycia przez Tarkowskiego kompozycji Bacha, możemy lepiej zrozumieć motywacje Hanekego: scjentystyczna rzeczywistość stacji kosmicznej tak samo „nie powinna” dopuszczać metafizyki, jak mieszkanie pary bohaterów Miłości, typowych mieszkańców zachodnioeuropejskich wielkich miast - agnostyków lub ludzi obojętnych religijnie. Poza tym Solaris Tarkowskiego był kręconym pod okiem wrogiego religii radzieckiego reżimu, więc bachowskie Ich rufzu Dir, Herr Jesus Christ osiąga w nim wymiar metafory także metafilmowej. Słysząc to samo preludium chorałowe w Miłości Hanekego, warto pamiętać, jak bardzo jest to muzyka „po przejściach”.

Szukając formalnego klucza, dzięki któremu muzyka może przenikać w głąb filmu, zwróciłem w niniejszej pracy uwagę na cechy upodabniające Pianistkę do kontrafaktury (czyli pewnego rodzaju „tłumaczenia” muzyki na język filmu). Są one zauważalne, kiedy muzyka podąża za myślami i uczuciami bohaterów lub za zmieniającą się dramaturgią wydarzeń (podobnie

${ }^{172}$ „Tarkowski [...], lekceważąc jednak protesty Lema, które sprowadzał do niezrozumienia istoty filmowości i twórczego przetwarzania, nie był w stanie zauważyć, że ekranowa wersja Solaris oznacza - na poziomie logiki inscenizacyjnej i odczytania bezpośredniego - intelektualną kompromitację adaptatora, przy czym nic tu nie mają do rzeczy wygłaszane maksymy w rodzaju »klarowność nie jest rzeczą najważniejsząu". Solaris [w:] A. Garbicz, Kino, wehikuł magiczny. Podróż czwarta 1967-1973, Kraków 2000, s. 488. 
jak np. w Amadeuszu Miloša Formana, z jego posępniejącym gwałtownie zakończeniem, odkąd Mozart dostaje zlecenie na napisanie Requiem), ale także kiedy wprowadza elementy kontrastu i ironii (jak np. w Kontrakcie rysownika Petera Greenawaya, gdzie reżyser pozostaje wierny realiom dawnej epoki, a uderza w nie pastiszem barokowej muzyki skomponowanym przez Michaela Nymana).

Inaczej jest w Miłości, gdzie większość formalnych środków wyrazu zmniejsza natężenie, a reżyser zamienia warsztatową błyskotliwość na dyskrecję (być może staje się po prostu błyskotliwie dyskretny). Muzyka pojawia się tu wyłącznie jako organiczny element filmowej diegezy, wpleciona między wydarzenia, czynności, przedmioty tak bardzo, że żaden utwór nie ma możliwości „satysfakcjonująco” wybrzmieć. Taka strategia Hanekego w interesujący sposób koresponduje z tezą Bohdana Pocieja, że dzięki muzyce film zbliża się do swojej „natury”, którą - według autora jest „ciążenie w dół, ku naturalizmowi, do poziomu [...] przed-sztuki” ${ }^{173}$. Za swoje ujmująco naturalne życie kompozycje płacą tym, czym się zwykle płaci za życie - kruchą śmiertelnością.

Losy bohaterów Miłości poznajemy z perspektywy kamery pokazującej $\mathrm{z}$ bliska ich codzienność, ale także z perspektywy utworów Beethovena czy Schuberta, które - inaczej niż kamera i cały filmowy warsztat - nie są elementami zewnętrznymi ani wobec filmowej historii (skorą brzmią „tam”, w paryskim mieszkaniu lub w pamięci bohaterów), ani wobec widza (skoro przez te dwa stulecie zdążyły przeniknąć w tkankę kulturową i społeczną, więc „mamy je w głowie”). To, co przychodzi z daleka, z dziejów muzyki, odzywa się w myślach i emocjach kinowego widza, a to, co widz uznaje za własne, osobiste, okazuje się obecne w dalekich nutach, napisanych dawno temu. Austriacki reżyser na pewno zna traktujący o tym wiersz austriackiego poety Rainera Marii Rilkego.

Michael Haneke w trzech omówionych przeze mnie filmach stopniowo emancypuje muzykę z pozycji narratora działającego wewnątrz filmu na pozycję metanarratora odzywającego się na zewnątrz: we wspólnej pamięci kulturowej i w głowie każdego widza. Reżyser za pomocą muzyki ożywia filmową historię, nadaje jej naturalność prawdziwego życia, ale robi też

${ }_{173}$ B. Pociej, Uwagi o muzyce filmowej, „Kwartalnik Filmowy” 1994, nr 6. 
na odwrót: za pomocą sztuki filmowej ożywia kompozycje sprzed stuleci, uruchamia ich kreacyjne możliwości, sprawczą moc. Jak zauważył Carl Dahlhaus: „Historia oddziaływania muzyki [...] nie jest wobec samych dzieł »zewnętrzna«, lecz przenika ich istotę, którą należy zatem pojmować jako historycznie zmienną"174. Haneke, niedoszły muzyk, który jako reżyser szczęśliwie wraca do partytur i instrumentów, dobrze o tym wie. Ta spełniona, serdeczna wzajemność - sztuki muzycznej i filmowej - jest być może największym osiągnięciem Michaela Hanekego.

\section{Bibliografia}

Charles Altman, W stronę teorii gatunku filmowego, [brak tłumacza], „Kino” 1987, nr 6.

Stanisław Barańczak, Podróż zimowa. Wiersze do Muzyki Franza Schuberta, Wydawnictwo a5, Warszawa 1994.

Jean Baudrillard O uwodzeniu, tłum. J. Margański, Wydawnictwo Sic!, Warszawa 2005.

Iwona Cegiełkówna, Miłość, „Kino” 2012, nr 11.

Iwona Cegiełkówna, Pianistka, „Cinema Polska” 2001, nr 11.

Janusz Cegiełła, Szkice do autoportretu polskiej muzyki współczesnej. Rozmowy z kompozytorami, Polskie Wydawnictwo Muzyczne, Kraków 1976.

Michel Chion, Audio-wizja. Dźwięk i obraz w kinie, tłum. K. Szydłowski, Ha!art, Warszawa - Kraków 2012.

Carl Dahlhaus, Estetyka muzyki, tłum. Z. Skowron, Wydawnictwo Uniwersytetu Warszawskiego, Warszawa 2007.

Carl Dahlhaus, „Rozumienie” muzyki i język analizy muzycznej, [w:] idem, Idea muzyki absolutnej i inne studia, tłum. A. Buchner, Polskie Wydawnictwo Muzyczne, Kraków 1988.

Piotr Dumała, Anioły śmierci w krótkich spodniach, „Kino” 1998, nr 5.

Łukasz Dziatkiewicz, Narodziny filmowej cenzury, „Dziennik”, dodatek „Weekend” $\mathrm{z}$ dn. 31.05.2014 r.

Umberto Eco, Dzieło otwarte. Forma i nieokreśloność w poetykach współczesnych, tłum. L. Eustachiewicz, W.A.B., Warszawa 2008.

${ }_{174}$ C. Dahlhaus, „Rozumienie” muzyki i język analizy muzycznej, [w:] idem, Idea muzyki absolutnej i inne studia, tłum. A. Buchner, Kraków 1988, s. 283. 
Umberto Eco, Tryb symboliczny, [w:] Teorie literatury XX wieku. Antologia, red. A. Burzyńska i M.P. Markowski, Znak, Kraków 2006.

Borys Eichenbaum, Problemy stylistyki filmowej, [w:] Estetyka ifilm, red. A. Helman,

Wydawnictwa Artystyczne i Filmowe, Warszawa 1972.

Alfred Einstein, Muzyka w epoce romantyzmu, tłum. M. Jarocińska, S. Jarociński,

Państwowe Wydawnictwo Muzyczne, Kraków 1983.

Encyklopedia kina, red. T. Lubelski, Wydawnictwo Biały Kruk, Kraków 2003.

Era Wilków [z Michaelem Hanekem rozmawiają Anna Chorestecka i Jan Niedziela],

„Gazeta Wyborcza” 2001, nr 278.

Fabryka zapomnienia [wywiad z Michaelem Hanekem], (przedruk z „Die Zeit”), „Forum” 2006, nr 6.

Paweł T. Felis, Czy fikcja jest prawdziwa?, „Gazeta Wyborcza” 2008, nr 296.

Paweł T. Felis, Haneke w Łodzi: Tematy same mnie znajduja, „Gazeta Wyborcza” 2013, nr 240.

Paweł T. Felis, Skandal śmierci, „Przekrój” 2012, nr 44.

Michel Foucault, Nadzorować i karać. Narodziny więzienia, tłum. T. Komendant, Aletheia, Warszawa 1998.

Adam Garbicz, Jacek Klinowski, Kino, wehikuł magiczny. Podróż pierwsza 1913-1949, Wydawnictwo Literackie, Kraków 1981.

Adam Garbicz, Kino, wehikuł magiczny. Podróż czwarta 1967-1973, Wydawnictwo Literackie, Kraków 2000.

Adam Garbicz, Kino. Wehikuł magiczny. Podróż piąta 1974-1981, Wydawnictwo Literackie, Kraków 2009.

Andrzej Hejmej, Słuchać i czytać: Dwa źródła jednej strategii interpretacyjnej. „Podróż zimowa” Stanisława Barańczaka, „Pamiętnik Literacki” 1999, z. 2. Alicja Helman, Funkcja muzyki i słowa w przekazie filmowym, [w:] Z zagadnień semiotyki sztuk masowych, red. A. Helman, M. Hopfinger, H. Książek-Konicka, Ossolineum, Wrocław - Kraków - Gdańsk 1977.

Alicja Helman, Na ścieżce dźwiękowej: o muzyce w filmie, Polskie Wydawnictwo Muzyczne, Kraków 1968.

Alicja Helman, Jacek Ostaszewski, Historia myśli filmowej, słowo/obraz terytoria, Gdańsk 2007.

Historia kina, t. I: Kino nieme, red. T. Lubelski, I. Sowińska, R. Syska, Universitas, Kraków 2009

Historia kina, t. II: Kino klasyczne, red. T. Lubelski, I. Sowińska, R. Syska, Universitas, Kraków 2012. 
Barbara Hollender, Za granica normalności, „Rzeczpospolita” 2001, nr 252. Barbara Hollender, Okrutna „Pianistka”, „Rzeczpospolita” 2004, nr 237. Alicja Jarzębska, Dialektyczny dyskurs Dahlhausa, „Ruch Muzyczny” 2009, nr 6. Elfriede Jelinek, Pianistka, tłum. R. Turczyn, Wydawnictwo W.A.B., Warszawa 2004.

Tomasz Jopkiewicz, Funny Games, „Film” 1999, nr 9.

Zygmunt Kałużyński, Buntownik bywalec, Wydawnictwo Ars, Warszawa 1998.

Zygmunt Kałużyński, Duch zezwierzęcony, „Polityka” 2001, nr 49.

Zygmunt Kałużyński, Weekend z mordercami, „Polityka” 1998, nr 14.

Zygmunt Kałużyński i Tomasz Raczek, Pojedynek z seksem, „Wprost” 2001, nr 47. Józef Kański, Przewodnik operowy, Polskie Wydawnictwo Muzyczne, Kraków 1985. Søren Kirkegaard, Dziennik uwodziciela, tłum. S. Lack, M. Bienenstock, Hachette, Warszawa 2009.

Piotr Kletowski, Filmowy (?) świat Markiza De Sade, „Ha!art” 2007, nr 2/3.

Krzysztof Kłopotowski, Zawód: artysta sadomasochista, „Rzeczpospolita” 2013, nr 138.

Jaga Kolawa, Bartosz Żurawiecki, DV Drama. Pianistka, „Świat Filmu” 2002, nr 2. Siegfried Kracauer, Teoria filmu. Wyzwolenie materialnej rzeczywistości, tłum.

W. Wertenstein, słowo/obraz terytoria, Gdańsk 2008.

Beata Kosińska-Krippner, „Funny Games”, czyli przemoc w białych rękawiczkach, „Kwartalnik Filmowy” 1998, nr 21/22.

Kultura dźwięku. Teksty o muzyce nowoczesnej, red. Ch. Cox, D. Warner, tłum. J. Kutyła, słowo/obraz terytoria, Gdańsk 2010.

Wojciech Kuczok, Pokątne pragnienia, „Tygodnik Powszechny” 2001, nr 50.

Krzysztof Kwiatkowski, Bez ckliwości, „Wprost” 2012, nr 44.

Zofia Lissa, Czy muzyka jest sztuką asemantyczną?, „Myśl Współczesna” 1948, nr 10.

Zofia Lissa, Estetyka muzyki filmowej, Polskie Wydawnictwo Muzyczne Kraków 1964.

Tadeusz Lubelski, Drzwi zamknięte, drzwi otwarte, „Ekrany” 2012, nr 6.

Tadeusz Lubelski, Rytuały powszechne, „Tygodnik Powszechny” 1998, nr 15.

Antoni Łazarkiewicz, Muzyka z podświadomości. Praktyczne i teoretyczne aspekty wykorzystania muzyki w filmie na podstawie analizy „Lśnienia” Stanleya Kubricka, „Glissando” 2007, nr 10.

Janusz Łętowski, Muzyka klasyczna na płytach kompaktowych, Twój Styl, Warszawa 1997.

Tadeusz Marek, Schubert, Państwowe Wydawnictwo Muzyczne, Kraków 1988. 
Marshall McLuhan, Zrozumieć media. Przedłużenia człowieka, tłum. N. Szczucka, Wydawnictwa Naukowo-Techniczne, Warszawa 2004.

Łukasz Maciejewski, Bohaterstwo przez rezygnacje, „Dziennik. Gazeta Prawna” $\mathrm{z}$ dn. 11.02.2012 r.

Ewa Mazierska, Bez litości, „Film” 2002, nr 4.

Magdalena Michalska, Bezlitosny świat Michaela Hanekego, „Dziennik” 2009, nr 171.

Miłość aż po grób [z Emmanuelle Rivą rozmawia Krzysztof Kwiatkowski], „Wysokie Obcasy" 2012, nr 44.

Miłość, czyli rana [z ks. Andrzejem Luterem rozmawia Katarzyna Jabłońska], „Więź" 2012, nr 10.

„Miłość, jakkolwiek by było [z Michaelem Hanekem rozmawia Tadeusz Sobolewski], „Gazeta Wyborcza” 2012, nr 123.

Edgar Morin, Kino i wyobraźnia, tłum. K. Eberhardt, Państwowy Instytut Wydawniczy, Warszawa 1975.

Nie chcę nikogo pouczać [z Michaelam Hanekem rozmawia Joanna Grabiańska], „Kino” 1995, nr 12.

Nie ma szczęścia bez bólu [z Jeanem-Louisem Trintignantem rozmawia Barbara Hollender], „Rzeczpospolita” 2012, nr 255.

Jan Olszewski, Kto to lubi?, „Film” 1998, nr 5.

José Ortega y Gasset, Bunt mas, tłum. P. Niklewicz, Wydawnictwo Muza, Warszawa 2008.

Jacek Ostaszewski, Słownik filmu, Krakowskie Wydawnictwo Naukowe, Kraków 2010.

Karolina Pasternak, Czuły barbarzyńca, „Newsweek Polska” 2012, nr 23.

Zdzisław Pietrasik, Pornografia bez porno, „Polityka” 2001, nr 44.

Anita Piotrowska, Nigdy nie ustaje, „Tygodnik Powszechny” 2012, nr 45.

Łukasz Plesnar, Semiotyka filmu, Wydawnictwo Uniwersytetu Jagiellońskiego, Kraków 1990.

Jerzy Płażewski, Język filmu, Książka i Wiedza, Warszawa 2008.

Jerzy Płażewski, Prośba o cztery jajka, „Kino” 1998, nr 3.

Bohdan Pociej, Uwagi o muzyce filmowej, „Kwartalnik Filmowy” 1994, nr 6.

Leszek Polony, Kilar. Żywioł i modlitwa, Polskie Wydawnictwo Muzyczne, Kraków 2005.

Adam Poprawa, Drogowskazy muzyki. O trasach zimowej podróży Schuberta, Müllera oraz Barańczaka, „Warsztaty Polonistyczne” 1995, nr 1. 
Adriana Prodeus, Miłość, „Film” 2010, nr 10.

Rola muzyki w dziele filmowym (ankieta), „Kwartalnik Filmowy” 1961, nr 2.

Umberto Rossi, Haneke atakuje, tłum. J. Płażewski, „Kino” 2001, nr 9.

Matthew Rye, 1001 albumów muzyki klasycznej, tłum. A. Fulińska, Wydawnictwo Elipsa, Poznań 2003.

Małgorzata Sadowska, Michael Haneke: cichy włamywacz, „Newsweek” 2012, nr 44. Piotr Sawicki, Czas i energia. Kurosawa a muzyka, [w:] Akira Kurosawa - twórca japoński, twórca światowy, red. W. Laskowska-Smoczyńska, P. Kletowski, Centrum Sztuki i Techniki Japońskiej Mangha, Kraków 2011.

Bogusław Schaeffer, Dzieje muzyki, WSiP, Warszawa 1985.

Bogusław Schaeffer, Dzieje kultury muzycznej, WSiP, Warszawa 1987.

Sławomir Sikora, O miłości Michaela Hanekego trochę inaczej, „Kwartalnik Filmowy" 2013, nr 83-84.

Peter Sloterdijk, Kryształowy pałac. O filozoficzna teorię globalizacji, tłum. B. Cymbrowski, Wydawnictwo Krytyki Politycznej, Warszawa 2011.

Tadeusz Sobolewski, Haneke. Wściekły i podstępny, „Gazeta Wyborcza”, dodatek „Duży Format” 2009, nr 45.

Tadeusz Sobolewski, Haneke z miłościa, ale bez litości, „Gazeta Wyborcza” 2012, nr 256.

Tadeusz Sobolewski, Mistrz okrutnych ciosów, „Gazeta Wyborcza” 2013, nr 244.

Tadeusz Sobolewski, Porno-Schubert, „Gazeta Wyborcza” 2001, nr 254.

Paweł Sołodki, Rubieże przyjemności. Seksualna niesubordynacja na obrzeżach amerykańskiej kinematografii, Wydawnictwo Naukowe Katedra, Gdańsk 2015.

Susan Sontag, Duchowy styl filmów Roberta Bressona, „Film na Świecie” 1999, nr 400.

Andrzej Sosnowski, Taxi, Biuro Literackie, Wrocław 2003.

Iwona Sowińska, Polska muzyka filmowa 1945-1968, Wydawnictwo Uniwersytetu Śląskiego, Katowice 2006.

Iwona Sowińska, Dźwięki i obrazy. O słuchaniu filmów, Wydawnictwo Śląsk, Katowice 2001.

Iwona Sowińska, Kilka trudności z historią muzyki filmowej, „Kwartalnik Filmowy” 2003, nr 44.

Jacek Szczerba, Cztery razy miłość, „Gazeta Wyborcza” 2012, nr 282.

Agnieszka Szeffel, Zobaczone, przeczytane, „Zeszyty Literackie” 1999, z. 1.

Wiktor Szkłowski, Sztuka jako chwyt, tłum. R. Łużny, [w:] Teoria badań literackich za granica: Antologia, t. 2: Od przełomu antypozytywistycznego do 
roku 1945, cz. 3: Od formalizmu do strukturalizmu, wyb. S. Skwarczyńska, Wydawnictwo Literackie, Kraków 1986.

Kamil Śmiałkowski, Niezabawne gry, „Wprost” 2004, nr 22.

Andriej Tarkowski, Czas utrwalony, tłum. S. Kuśmierczyk, Wydawnictwo Świat Literacki, Warszawa 2007.

Jan Topolski, Kino/Muzyka. Zbliżenia. Gambit Kubricka, „Ruch Muzyczny” 2009, nr 8.

Jan Topolski, 27 fragmentów socjologii przypadku: haneke, „Odra” 2010, nr 1.

Emilia Walczak, Od Brechta do Jelinek. Michael Haneke - antyspektakularna trauma Realnego, „Kwartalnik Filmowy” 2008, nr 64.

Alan Williams, Historyczne i teoretyczne problemy wprowadzenia do kina ścieżki dźwiękowej, „Kwartalnik Filmowy” 2004, nr 44.

Piotr Wojciechowski, Pani od gry..., „Film” 2001, nr 11.

Janusz Wróblewski, Okrutne gry, „Polityka” 2004, nr 22.

Wrzątek podany na zimno [z Michaelem Hanekem rozmawia Paweł Felis], „Gazeta Wyborcza" 2013, nr 244.

Wszystkie moje filmy sq obsceniczne [z Michaelem Hanekem rozmawia Joanna Grabiańska], „Kino” 2002, nr 1.

Ernest Zavarsky, J.S. Bach, tłum. M. Erhardt-Gronowska, Polskie Wydawnictwo Muzyczne, Kraków 1985.

Piotr Zawojski, Przypisy do „Ukrytego” Michaela Hanekego, „Opcje” 2006, nr 4. Jacek Ziemek, Wiedeń - Schubert - Seks, „Przekrój” 2001, nr 48.

Jerzy Ziomek, Kontrafaktura, [w:] Między tekstami. Intertekstualność jako problem poetyki historycznej, red. J. Ziomek, J. Sławiński, W. Bolecki, PWN, Warszawa 1992.

Łukasz Ziomek, Hymn L’Amour?, „Kino” 2013, nr 1.

\section{Źródła internetowe}

Darek Arest, Haneke, not so funny, http://wyborcza.pl/1,91947,5547054,Haneke Not_so_funny.html\#ixzz0z3EHXFv7.

Rafał Błaszczak, Miłość, http://kafeteria.pl/kultura/milosc-michael-haneke-a_5375. Jędrzej Dudkiewicz „Funny Games” czyli po co to oglądasz? - analiza filmu Michaela Hanekego, http://film.org.pl/a/analiza/funny-games-czyli-po-co-to-ogladasz -analiza-filmu-michaela-hanekego-36176/.

Kinga Dunin, Kobiece marzenie o dobrej śmierci, www.krytykapolityczna.pl/ felietony/20122407/kobiece-marzenie-o-dobrej-smierci. 
Katarzyna Frankowska, „,Miłość” Hanekego - przerwany chorał Bacha, http://www. tvp.info/8968512/milosc-hanekego-przerwany-choral-bacha.

Funny Games (recenzja), www.twojefilmy.pl/funny-games/.

Ryan Gilbey, "Amour” and the music of time, www.newstatesman.com/ culture/2012/11/michael-hanekes-amour-and-music-time.

Piotr Gociek, Chory film o miłości, http://wpolityce.pl/kultura/246542-premiera -kinowa-michaela-haneke-chory-film-o-milosci-nasza-recenzja.

Malwina Grochowska, Miłość ponad wszystko, www.filmweb.pl/reviews/ Mi\%C5\%820\%C5\%9B\%C4\%87+ponad+wszystko-12843.

Michael Haneke w rozmowie z Sergem Toubianą, https://www.youtube.com/ watch?gl=PL\&hl=pl\&v=roOl9PvEPjs.

Lamos Ignoramus, Michael Haneke's „Funny Games” and the Lie of Reality, http:// filmslie.com/michael-hanekes-funny-games-lie-reality/.

Iwona Kurz, Potworność. O Michaelu Hanekem, www.dwutygodnik.com/artykul/ 4135-potwornosc-o-michaelu-hanekem.html.

Jakub Majmurek, Claude Chabrol (1930-2010) cyniczny (a)moralista, www.dwutygodnik.com/artykul/1486-claude-chabrol-1930-2010-cyniczny-amoralista. html.

Jakub Majmurek, I to jest ta cała miłość?, www.krytykapolityczna.pl/Blogfilmowy/ MajmurekItojesttacalamilosc/menuid-85.html.

Michael Haneke dedykuje „Miłość” ciotce, www.canalplus.pl/film/ news-michael-haneke-dedykuje-milosc-ciotce_40195.

Music in „Amour”, http://framescourer.blogspot.com/2012/11/music-in-amour-2012. html.

Narodowy Instytut Fryderyka Chopina, http://pl.chopin.nifc.pl/chopin/genre/ detail/id/21 oraz http://pl.chopin.nifc.pl/chopin/composition/detail/id/112.

Krzysztof Niweliński, Zorn, John - Naked City, http://artrock.pl/recenzje/51397/ zorn_john_naked_city.html.

Michał Oleszczyk, Biała wstążka, http://www.dwutygodnik.com/artykul/595-biala-wstazka-rez-michael-haneke.html.

Michał Oleszczyk, Miłość, http://www.dwutygodnik.com/artykul/4067-milosc-rez-michael-haneke.html.

Pianistka (recenzja), https://xmuza.wordpress.com/2012/06/11/la-pianiste-2001 -michael-haneke.

Monika Piechocka i Agata Kortus, filmowy blog „inlovewithmovie”, http://inlovewithmovie.blogspot.com/2013/03/miosc-amour.html. 
Podróż zimowa. Wiersze do Muzyki Franza Schuberta, www.wydawnictwoa5.pl/

Podroz-zimowa-Wiersze-do-muzyki-Franza-Schuberta;s,karta,id,174.

Marcin Poprawski, Muzykologiczne aspekty interpretacji „Podróży zimowej”

Stanisława Barańczaka, www.demusica.pl/cmsimple/images/file/poprawski_muzykalia_5_1.pdf.

Paweł Rezmer, Miłość, http://stacjakultura.pl/4,21,29422,Milosc_recenzja_filmu,artykul.html.

Małgorzata Sadowska, Martwa natura. Z gołęiem, www.canalplus.pl/film/ blog-malgorzata-sadowska-martwa-natura-z-golebiem_961_11.

Tadeusz Sobolewski, Ból wolności - ekranizacja „Pianistki”, http://wiadomosci. gazeta.pl/wiadomosci/1,114873,2328011.html.

Krzysztof Świrek „Miłość" według najlepszych zasad. O regułach w filmach Michaela Hanekego, http://kulturaliberalna.pl/2012/11/13/swirek-milosc-wedlug-najlepszych-zasad-o-regulach-w-filmach-michaela-hanekego-esej/.

Jan Topolski, Muzyka w filmach Stanleya Kubricka, http://stopklatka.pl/news/ muzyka-w-filmach-stanleya-kubricka.

Tymoteusz Wojciechowski, Dźwięk w kinie, http://film.org.pl/a/artykul/dzwiek -w-filmie-cz-3-dusze-czarne-32371/; http://film.org.pl/a/artykul/dzwiek -w-filmie-cz-4-komedie-rene-claira-32764/; http://film.org.pl/a/analiza/ dzwiek-w-kinie-cz-5-aleksander-newski-36801/; http://film.org.pl/a/artykul/ dzwiek-w-kinie-cz-5-jean-luc-godard-34204/.

Katarzyna Wolanin, Zrozumieć Michaela Haneke, http://liberte.pl/zrozumiec -michaela-haneke/.

The World That Is Known [Michael Haneke $\mathrm{w}$ rozmowie z Christopherem Sharrettem], http://www.kinoeye.org/04/01/interview01.php.

Artur Zaborski [o filmie Wulkan w reż. Rúnara Rúnarssona], www.nowehoryzonty. $\mathrm{pl} /$ film.do?id=5286\&ind=page\%3d0\%26typ\%3ddz\%26edycjaFest $\% 3 \mathrm{~d} 11 \%$ 26czas\%3d15\%253a45\%26dzien\%3d26 [dostęp: 30.05.2016].

Dominika Zielińska, Antyhumanizm Michaela Hanekego, http://bad-taste.pl/ antyhumanizm-michaela-hanekego.

\section{Filmografia}

24 Realities per Second: A Documentary on Michael Haneke, reż. N. Kusturica i E Testor, 2005.

Amadeusz, reż. Miloš Forman, 1984.

Aleksander Newski, reż. Siergiej Eisenstein, 1938. 
Błękitny anioł, reż. Josef von Sternberg, 1931.

Bulwar Zachodzącego Stońca, reż. Billy Wilder, 1950.

Burza nad Azja, reż. Wsiewołod Pudowkin, 1928.

Ceremonia, reż. Claude Chabrol, 1995.

Człowiek z kamerą, reż. Dżiga Wiertow, 1929.

Dajcie mi głowę Alfredo Garcii, reż. Sam Peckinpah, 1974.

Dawno temu w Ameryce, reż. Sergio Leone, 1984.

Don Juan, reż. Alan Crosland, 1926.

Dusze czarnych, reż. King Vidor, 1930.

Dzika banda, reż. Sam Peckinpah, 1969.

Frantic, reż. Roman Polański, 1988.

Funny Games, reż. Michael Haneke, 1997.

Gwiezdne wojny, reż. George Lucas, 1977.

Gwiezdne wojny: Przebudzenie mocy, reż. J.J. Abrams, 2015.

Hiroshima, moja miłość, reż. Alain Rensais, 1959.

Kobieta i mężczyzna, reż. Claude Lelouch, 1966.

Kobieta jest kobieta, reż. Jean Luc Godard, 1960.

Koronczarka, reż. Claude Goretta, 1977.

Kontrakt rysownika, reż. Peter Greenaway, 1982.

Lśnienie, reż. Stanley Kubrick, 1980.

Łowca Androidów, reż. Ridley Scott, 1982.

Michael Haneke: My life, reż. Felix i Gero von Boehm, 2009.

Miłość, reż. Michael Haneke, 2012.

Misja, reż. Roland Joffé, 1986.

My z Kronsztadu, reż. Jefim Dzigan, 1932.

Narodziny narodu, reż. David W. Griffith, 1915.

Obywatel Kane, reż. Orson Welles, 1941.

Pani Bovary, reż. Claude Chabrol, 1991.

Parasolki z Cherbourga, reż. Jacques Demy, 1964.

Październik, reż. Siergiej Eisenstein, 1929.

Pianistka, reż. Michael Haneke, 2001.

Pod dachami Paryża, reż. René Clair, 1930.

Pokój 237, reż. Rodney Ascher, 2012.

Psychoza, reż. Alfred Hitchcock, 1960.

Pulp Fiction, reż. Quentin Tarantino, 1994.

Pustynia Tatarów, reż. Valerio Zurlini, 1976. 
Siedmiu samurajów, reż. Akira Kurosawa, 1954.

Siedmiu wspaniałych, reż. John Sturges, 1960.

Siódmy kontynent, reż. Michael Haneke, 1989.

Solaris, reż. Andriej Tarkowski, 1972.

Straż Przyboczna, reż. Akira Kurosawa, 1961.

Śpiewak jazzbandu, reż. Alan Crosland, 1927.

Światła Nowego Jorku, reż. Bob Foy, 1928.

Taksówkarz, reż. Martin Scorsese, 1974.

Trzy kolory. Czerwony, reż. Krzysztof Kieślowski, 1994.

Turbina 50 000, reż. Siergiej Rutkiewicz i Fridrich Ermler, 1932.

Ukryta forteca, reż. Akira Kurosawa, 1958.

Wielka ucieczka, reż. John Sturges, 1963.

Zabójstwo księcia Gwizjusza, reż. Charles le Bargy i André Calmettes, 1908.

\section{Music as a Narrative Resource in Selected Films of Michael Haneke}

The author of the article analyzes the narrative role of music in Michael Haneke's films. In terms of content, three movies are discussed: Funny Games (1997), The Piano Teacher (2001) and Amour (2012).

The selection of films was made on the basis of diversed musical plot devices used there. Additionally, these films show how role of music evolve over the years into more profound view inside events horizon, full-bodied commentary to film's action and liberation from optical invigilation of camera.

The goal of this paper is to show why narrative resource has crucial impact on artistic weight of Haneke's films. The director renounces interpretation of his films by giving them their own life - the life of the open work. The article rises the argument that music supports the strategy of director. Moreover, it indicates that emancipation of the music entails the emancipation of heroes and diegetic reality.

Keywords: Michael Haneke, Funny Games, The Piano Teacher, Amour, film score, film narrative 